\title{
Uma Estratégia para Iniciar Melhoria de Processo de Software
}

\author{
Cristina Endo \\ Orientadora: Profa. Dra. Rosely Sanches
}

Dissertação apresentada ao Instituto de Ciências Matemáticas e de Computação - USP, como parte dos requisitos para a obtenção do título de Mestre em Ciências Área: Ciências de Computação e Matemática Computacional. 
Aos meus queridos pais: Takeshi e Rosa 


\section{Agradecimentos}

À Rosely que além de orientar este trabalho, sem dúvida, é uma das melhores pessoas que já conheci.

À família toda, meus pais Takeshi e Rosa, aos meus irmãos Hiolanda, Regina, Mario, Mário, Lumi, por acompanhar-me, incentivar-me e principalmente, dedicar-me tanto carinho.

Ao Eduardo, por estar sempre presente, apesar da distância, incentivando, transmitindo segurança e principalmente sendo a minha fonte de paz e tranqüilidade.

Aos primos Júlia e Yoshinori pelo carinho, atenção e amizade dedicados durante toda a graduação e mestrado.

À amiga Juliana, por me ensinar o que é uma verdadeira amizade.

Às amigas da minha atual república, Carol, Eiaine, Larissa, Aline e Sandrinha, pela paciência, amizade e companheirismo.

Às amigas Jaque, Ana Elisa e Marisa pelo carinho, amizade e pelos momentos de reflexão.

Ao Paulinho, Zé Angelo, Jaques, Marilia, Beth, Laura, Cabral, Fanz, Luis, Luciano, Sónia pela atenção dedicada em momentos dificeis.

Aos companheiros do LABES, Andréa, Elisa, Rejane, Theima, Thati, Luciana, Valéria, João Caldas, Ana Paula, Marcos Quinaia, Sandra, Auri, Ellen, Simone, Maldonado, Renata, Rogério, Djalma, Janaina, Willie.

Aos amigos Omar, Marco, Paulo, Fábio, Xede, Mirla, Júlio, Sandra, Luciano, Rudnei, Fabiano, Mario, Garga, Maristeia, Patricia, Kutova, Ernesto, Luis Carlos, Guitherme, Arthur, Marcelo, Haroldinho, Rogério, Batata, Rubens e muitos outros amigos pelos momentos tão felizes e inesqueciveis vividos no mestrado.

A todos os professores do ICMC que sempre me incentivaram e se dedicaram pela minha formação profissional, além de estarem sempre dispostos a nos ajudar em tudo.

A todos os amigos da graduaçăo do ICMC, em especial aos amigos da turma 91 , pela amizade, pelo carinho, pela convivência tão intensa que fizeram de nós uma família.

A todos os funcionários do ICMC que sempre foram muitos prestativos e amigos.

À CAPES pelo apoio financeiro. 


\section{Resumo}

Este trabalho apresenta uma estratégia que define, relaciona $\theta$ organiza as principais atividades que devem ser realizadas para avaliar um Processo de Software. É uma estratégia simples de executar e auxilia pequenas empresas a avaliar seu próprio processo de software em relação ao nível 2 do CMM. Foi desenvolvido também um instrumento de avaliação para coleta de dados, em forma de um questionário, que auxilia na execução da estratégia proposta.

- O trabalho também apresenta um estudo de caso realizado para a aplicação da estratégia e do questionário elaborados num centro de desenvolvimento de sistemas internos de uma universidade privada para validar o trabalho elaborado. 


\begin{abstract}
This work presents a strategy for defining, relating and organizing the main activities that should be done when assessing a Software Process. This strategy is easy to execute and helps small businesses to assess their own software process in relationship to level 2 of CMM. An assessment instrument for data collection was developed as a questionnaire for aiding the execution of the proposed strategy.

Finally, a case study is presented where the strategy and the questionnaire were applied at an internal system development center in a private university. This made it possible to evaluate the validity of the proposal.
\end{abstract}




\section{Sumário}

LISTA DE FIGURAS ........................................................................................................................................... iii

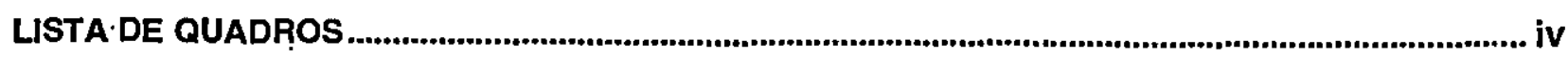

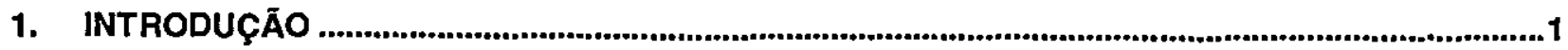

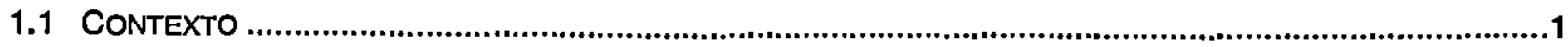

1.2 MOTIVAÇÃO

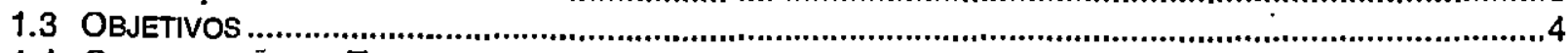

1.4 ORGANIZAÇĀODO TRABALHO

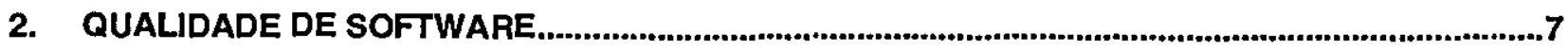

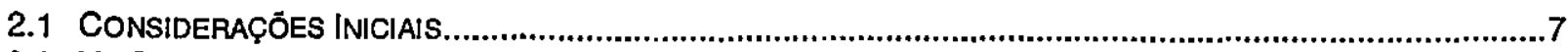

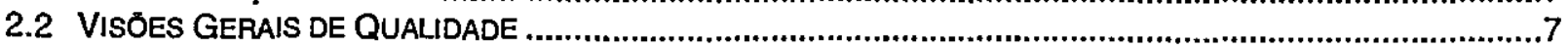

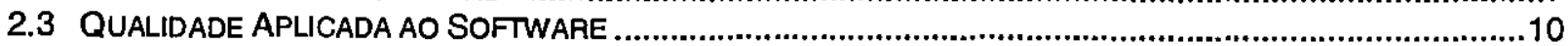

2.3.1 Qualidade de Produto de Software....................................................................13

2.3.2 Qualidade de Processo de Software ..................................................................13

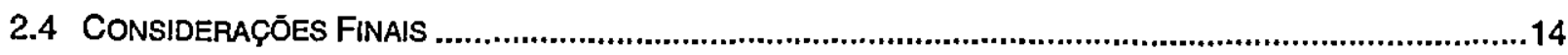

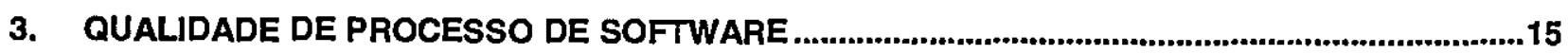

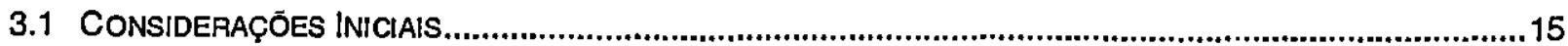

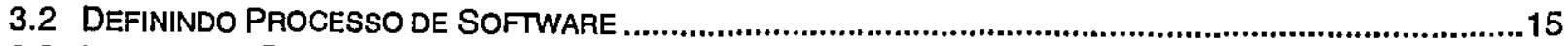

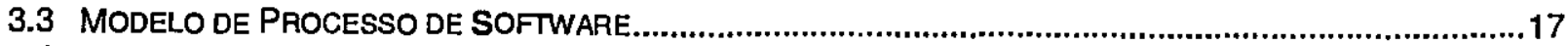

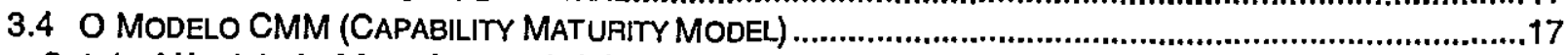

3.4.1 Nível 1 de Maturidade: Inicial ........................................................................... 18

3.4.2 Nível 2 de Maturidade: Repetível ..................................................................... 19

3.4.3 Nível 3 de Maturidade: Definido ........................................................................21

3.4.4 Nível 4 de Maturidade: Gerenciado......................................................................24

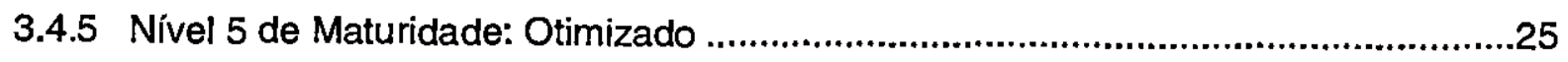

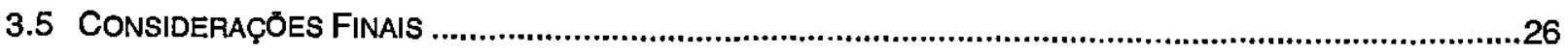

4. MELHORIA DE PROCESSO DE SOFTWARE ..............................................................................27

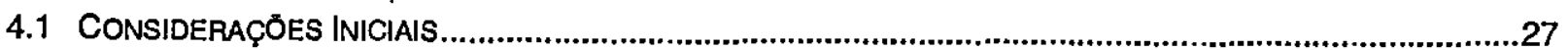

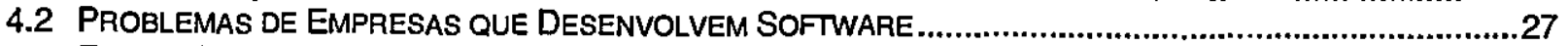

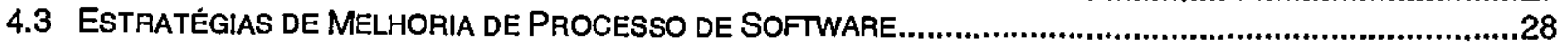

4.3.1 O Ciclo PDCA (Plan Do Check Act) ..............................................................29

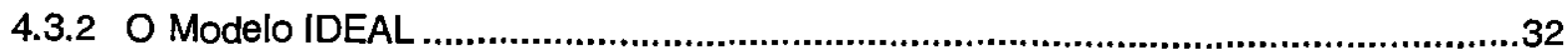

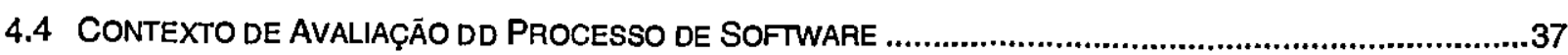

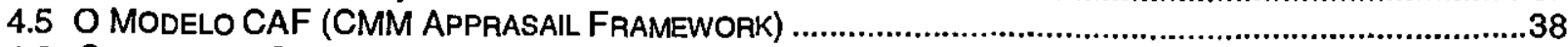

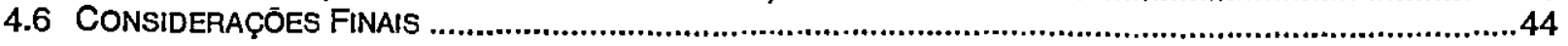

5. ELABORAÇÃO DO QUESTIONÁRIO E DO PLANO DE AVALIAÇĀO DE PROCESSO.................45 


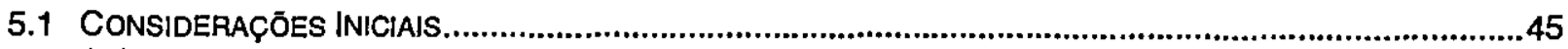

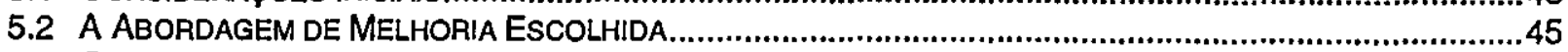

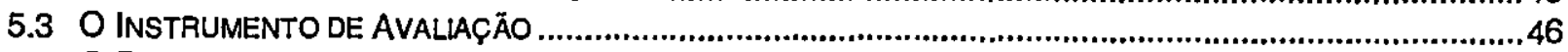

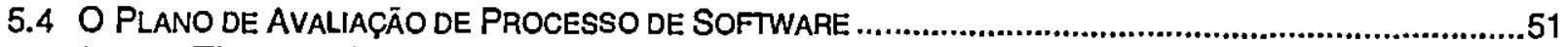

5.4.1 A Elaboração do Plano de Avaliação de Processo de Software .............................51

5.4.2 O Plano de Avaliação de Processo ....................................................................54

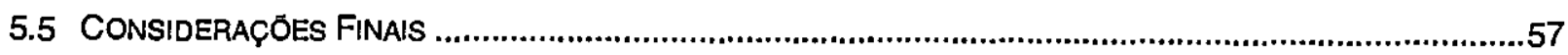

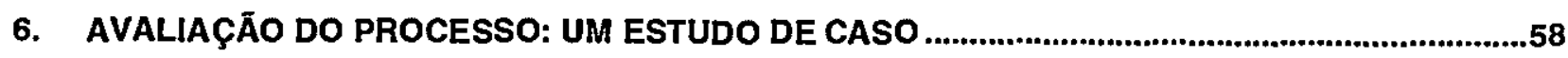

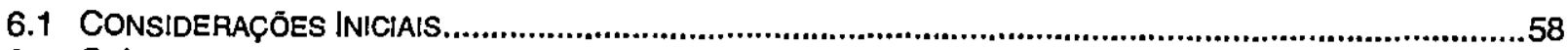

6.2 O AMBIENTE DE DESENVOLVIMENTO DE SOFTWARE DO ESTUDO DE CASO ...................................58

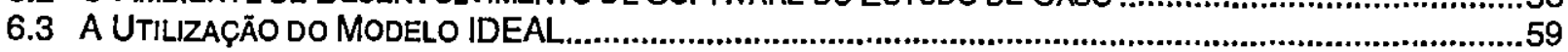

6.3.1 Fase de Inicialização do Estudo de Caso .............................................................59

6.3.2 A Fase de Diagnóstico do Estudo de Caso .........................................................60

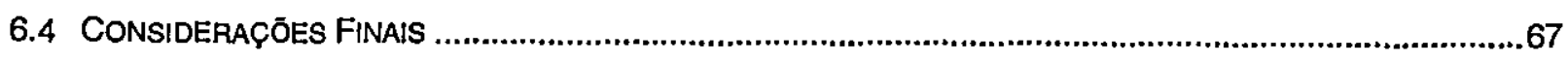

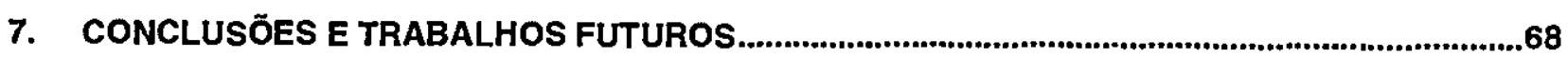

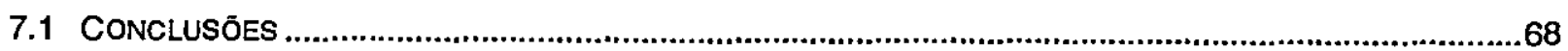

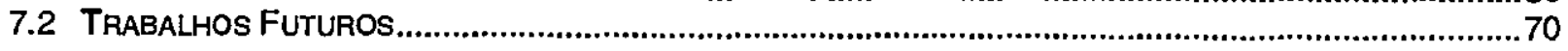

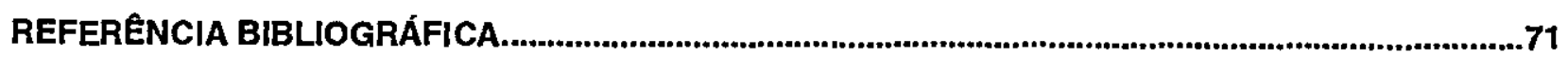

APÊNDICE 1: AS PRÁTICAS-CHAVES DO NÍVEL 2 DO CMM ............................................................77

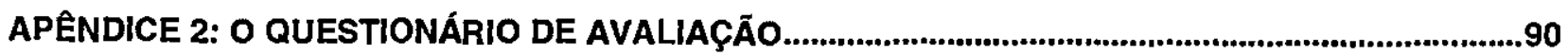

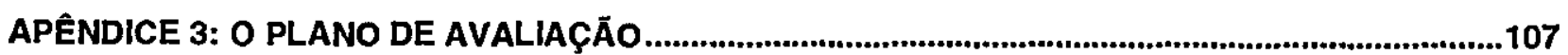




\section{Lista de Figuras}

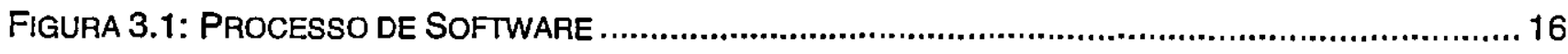

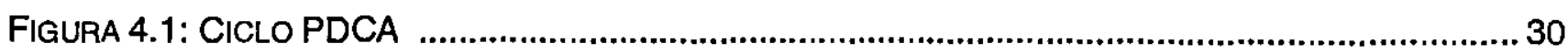

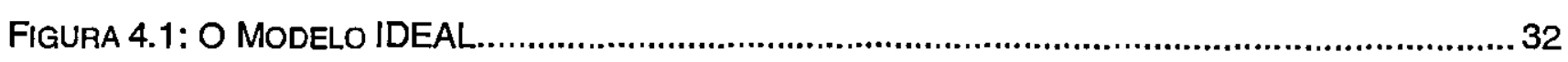

FIGURA 4.1: ARQUITETURA DO CAF COM ALGUMAS MODIFICAÇŌES............................................. 38

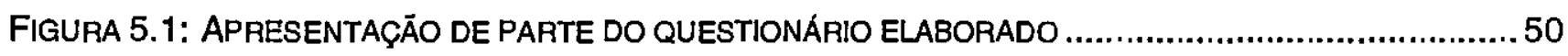

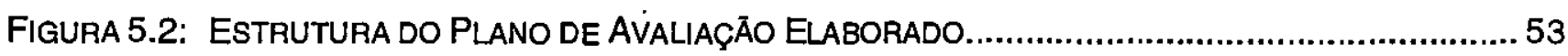

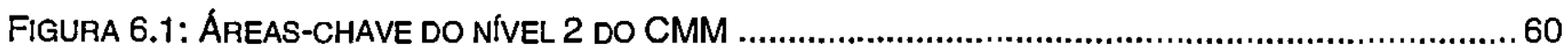

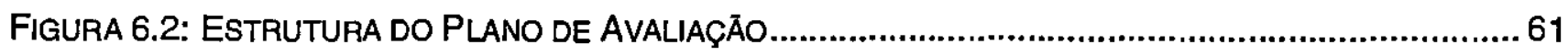

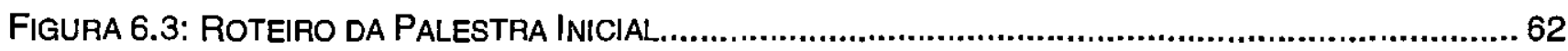

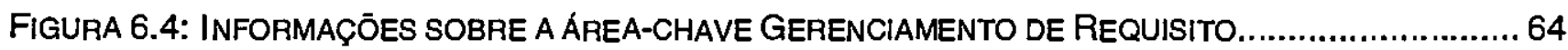

FiguRA 6.5: INFORMAÇÕES SOBRE A ÁREA-CHAVE PLANEJAMENTO de PROJETO de SOFTWARE.......... 64

FIGURA 6.6: INFORMAÇÕES SOBRE A ÁREA-CHAVE ACOMPANHAMENTO E SUPERVISĀo de PROJETO

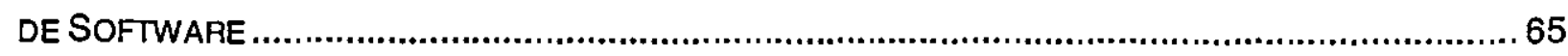

Figura 6.7: InFoRMAÇÕES SOBRe A ÁREA-CHAVE GARANTIA DE QUALIDAdE DE SOFTWARE ..............65

FIguRA 6.8: INFORMAÇÕES SOBRE A ÁREA-CHAVE GERENCIAMENTO dE CONFIGURAÇÃo dE

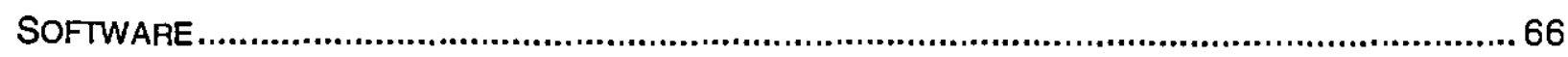

FiguRA 7.1: ESTRATÉGIA CRIAdA PARA A FASE DE DiagNóstico do IDEAL...................................6 69 


\section{Lista de Quadros}

QUADRO 2.1: CARACTERÍSTICAS E SUBCARACTERISTICAS DA NORMA ISO/IEC $9126 \ldots \ldots \ldots \ldots \ldots \ldots . . . . . . . . . . .14$

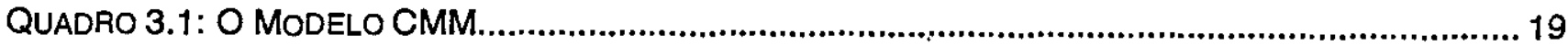

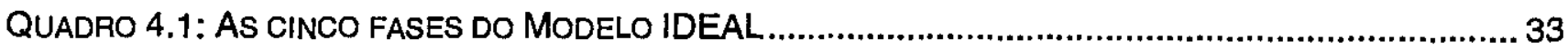

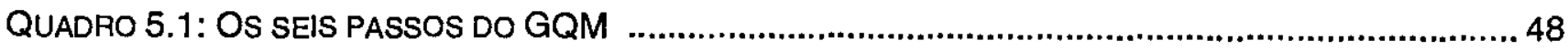

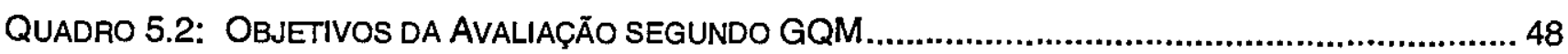




\section{Capítulo 1 - Introdução}

\subsection{Contexto}

A qualidade é um termo que pode ter diferentes interpretaçōes. Mas o grande consenso que existe, nos dias atuais, é que independentemente de qual interpretação esteja sendo usada, tanto para os prestadores de serviços, quanto para os produtores de algum produto, esse termo tem sido o grande diferencial no mercado atual.

Para softwares também não tem sido diferente. Quando se fala em qualidade de software, a visão mais intuitiva é aquela de que o produto de software tem qualidade quando satisfaz os requisitos que foram impostos pelos usuários [Silva, 1998]. Por isso, a primeira visão de qualidade de software concentra o esforço em avaliar a qualidade do produto de software depois de pronto, para que um produto defeituoso não chegue às mãos do cliente.

Dentro do estudo de qualidade de software, essa abordagem é conhecida como Qualidade de Produto de Software. Esforços apresentados por McCall (1977) e explicitados na norma ISO/lEC 9126 (1994) procuram definir um conjunto de fatores ou características que evidenciam a presença da qualidade do produto final. Essas características são definidas para representar necessidades e desejos daqueles que estão envolvidos direta ou indiretamente com o software [Tsukumoto, 1995].

Visões mais recentes de qualidade propõem um controle sobre o processo de desenvolvimento do produto, de modo que se garanta que o mesmo seja produzido de acordo com os padrões de qualidades impostos pelos termos do contrato. Essa visão é conhecida como Qualidade de Processo de Software [Lemes, 1997]. É importante lembrar ainda, que a qualidade do produto de software está diretamente ligada à qualidade de processo de software [Curtis, 1992].

Para que se possa executar e controlar as atividades de construção de software, é necessário possuir um ambiente adequado que garanta que isso possa ser realizado [Grady, 1997]. Esse ambiente é composto por pessoas e suas responsabilidades, recursos, cronogramas, orçamentos, o processo de desenvolvimento em si, técnicas, métodos e outros. 
Com a criaçāo desse ambiente adequado, as chances de que o produto final seja um produto de qualidade é muito grande [SPICE1, 1997].

Seguindo essa última abordagem, têm-se dado grande importância ao Processo de Software (ambiente adequado ao desenvolvimento de software) como forma de se garantir a construção de um software de melhor qualidade. Espera-se que um processo controlado propicie a reduçāo da variaçāo nos produtos em relação às suas especificaçōes. Nesse contexto, pode-se incluir ainda, a necessidade de se cumprir um cronograma e trabalhar dentro de um orçamento limitado, fazendo com que a produtividade seja um fator decisivo para o cumprimento efetivo dos objetivos de se construir um software [Taurino, 1997].

Definir e implantar um processo de software favorável à organização não é uma tarefa simples, uma vez que muitos elementos estão presentes e as atividades de implantação devem ser, devidamente, planejadas e controladas. Para auxiliar na implantação desse ambiente existem os chamados Modelos de Melhoria de Processo de Software. Esses modelos descrevem os passos que devem ser seguidos pela organização para que as diretrizes de um modelo de processo de software escolhido sejam implantadas e melhoradas.

Modelos como o PDCA [Werkema, 1995] e o IDEAL [Gremba, 1998] representam esses Modelos de Melhoria do Processo de Software. Em linhas gerias, esses modelos propõem um ciclo que contém atividades de diagnóstico do processo atual, elaboração de um plano de ação para melhoria, implantação desse plano e a confirmaçāo das atividades implantadas através do diagnóstico do processo, iniciando, novamente o ciclo.

Desse modo, para melhorar a qualidade no processo de software, é necessário, primeiro, conhecer a situação real em que se encontra a organização em matéria de produção de software, isto é, fazer um diagnóstico do processo de software corrente [Grady, 1997].

$\mathrm{Na}$ atividade de diagnóstico, deve-se primeiro, escolher o modelo de processo de software a ser implantado na organização, conhecendo-se assim, o ponto de referência para onde se deseja chegar. Como exemplo desses modelos de referências pode-se citar o CMM da SE] [Paulk, 1995] e a parte 2 do SPICE [SPICE2, 1997]. Esse diagnóstico tem a função de capturar os pontos fortes e fracos do processo corrente, em relação ao modelo de processo escolhido. Junto a esses pontos fortes e fracos, as metas de negócios almejadas são 
consideradas para definir prioridades para a elaboração de uma estratégia de melhoria de processo de software.

Dentro desse contexto, este trabalho consiste em definir um plano que auxilie na elaboração e condução das atividades que compõem a fase de diagnóstico de um processo de software, dentro do contexto de melhoria de processo de software de uma organização considerada pequena.

Esse contexto foi escolhido pela atual situação das organizações que desenvolvem softwares no Brasil que são na maioria micro e pequenas empresas (até 50 funcionários) [MCT, 1997] ou grandes organizações que desenvolvem seus próprios softwares para uso interno. E também por que a fase de diagnóstico de um processo de software é a fase inicial de um processo de melhoria.

Fornecer um plano para realizar diagnóstico, que possa ser executado facilmente, pode ser de grande ajuda para iniciar uma mudança na cultura das organizações, disseminando a necessidade de se ter um ambiente adequado para o desenvolvimento de software. Sem esse ambiente, nenhuma técnica e nenhuma ferramenta de apoio de desenvolvimento podem realizar milagres de conseguir produzir sempre, um produto com qualidade, dentro do custo, cronograma e recursos adequados.

\subsection{Motivação}

Dado o contexto no qual este trabaiho está inserido, alguns pontos relevantes que motivaram a realização do desenvolvimento do plano para diagnóstico são:

- a Engenharia de Software tem como um dos seus princípios básicos a qualidade de software;

- após décadas de promessas, não cumpridas totalmente, sobre ganhos na produtividade e qualidade pela aplicação de novas tecnologias e metodologias de software, as organizações industrlais e governamentais estão concluindo que seus problemas fundamentais estão na incapacidade em gerenciar o processo de software. 
- o contexto atual de desenvolvimento de software no Brasil:

- $31 \%$ dos projetos são cancelados antes de lançar o software;

- $9 \%$ dos projetos cumprem cronograma e entregam os produtos na data prevista;

- $75 \%$ dos sistemas grandes apresentam falhas operacionais;

- começam a surgir grandes preocupaçōes por partes das empresas brasileiras em tentar modificar o panorama atual do desenvolvimento de software;

- para se definir um processo numa empresa que possa ser aplicado a qualquer um de seu projeto, não se pode ignorar o que a empresa já possui estabelecida como sua "maneira" de desenvolver softwares;

- as estratégias para realizar um diagnóstico são, em geral, de propriedade de empresas de consultorias que costumam prestar serviços nessa área;

- o plano proposto neste trabalho pode ser interpretado e utilizado pelas empresas através de pessoas que pertençam à própria empresa e que sejam devidamente qualificadas, de maneira rápida e com baixo custo.

\subsection{Objetivos}

A realidade brasileira em relação ao desenvolvimento de software, comentada brevemente, é um dos principais focos deste trabalho.

A necessidade em mudar esse panorama já tem sido sentida por muitos profissionais nessa área. Mas, como qualquer outra estratégia que deve ser adotada por uma organização, a melhoria de processo de software deve ser muito bem planejada e controlada, pois consiste em uma seqüência de atividades e seus resultados geralmente são obtidos em longo prazo.

A Melhoria de Processo de Software não é uma atividade simples, pois muitos elementos que envolvem a organização como comprometimentos, responsabilidades, recursos, habilidade profissional e gerencial deve ser levada em conta. E para se propor uma melhoria, é imprescindível que primeiro seja traçado um panorama real em que a organização se encontra em matéria de desenvolvimento de software.

O objetivo deste trabalho é apresentar um plano que defina, relacione e organize as principais atividades que devem ser realizadas na fase de diagnóstico para implantar Melhoria 
de Processo de Software. Ou seja, elaborar uma abordagem simples que auxilie a organização a avaliar a situação atual do seu próprio processo de software. Neste trabalho, também foi desenvolvido um instrumento de avaliação para coleta de dados, em forma de um questionário, que auxilia na implantação do plano proposto.

O trabalho também apresenta um estudo de caso realizado num centro de desenvolvimento de sistemas internos de uma universidade privada, que tentou validar os resultados do trabalho.

\subsection{Organização do Trabalho}

Este trabalho encontra-se dividido em sete capítulos. Neste capítulo, descreve-se a contextualização do trabalho, a motivação que levou sua realização e os principais objetivos do trabalho.

No Caṕtulo 2, apresenta-se uma breve discussão sobre qualidade em termos gerais, qualidade aplicada ao software, e especificamente qualidade de produto de software.

No Capitulo 3 uma atenção especial é dada à discussão sobre qualidade de processo de software. Apresentam-se as definições dos termos utilizados como processos de software, qualidade de processo de software, modelos de processo de software. Descreve-se, detalhadamente, um modelo de processo de software definido pela SEI (Software Engineering Institute), o CMM (Capability Maturity Model).

Dois modelos de melhoria de processo de software apresentados pela literatura são descritos com mais detalhes no Capítulo 4: o modelo PDCA (plan-do-check-act), o mais antigo e já utilizado largamente na melhoria de processo de manufatura e o modelo IDEAL (InitiatingDiagnosing-Acting-Establishing-Learning), específico para processos de software. Ainda no Capítulo 4 apresenta-se o modelo CAF (CMM Appraisal Framework), utilizado para auxiliar a execução dos passos da fase de Diagnóstico do modelo IDEAL.

No Capítulo 5, descreve-se como se sucedeu a elaboração do instrumento de coleta de dados e o plano de avaliação do processo de software. Na elaboração do questionário foi 
usado $\circ$ GQM (Goal-Metric-Question). As etapas realizadas para elaboração do plano e o plano completo são apresentados ainda nesse capítulo.

No Capítulo 6, o estudo de caso específico é apresentado, bem como os resultados obtidos pela aplicação do plano, e do questionário proposto neste trabalho.

Finalmente no Capítulo 7, são apresentados as conclusões do trabalho, bem como os futuros desdobramentos que podem ser abordados a partir da realização deste trabalho. 


\section{Capítulo 2 - Qualidade de Software}

\subsection{Considerações Iniciais}

Neste capítulo é descrito, brevemente, o panorama do estudo da qualidade de software existente na literatura. Para isso, apresenta-se uma descrição da visão geral de qualidade, em seguida, define-se o termo qualidade que será aplicado ao estudo da qualidade de software. A apresentação desses conceitos é necessária para a definição e compreensão do contexto que está inserido este trabalho.

Ainda neste capítulo, apresenta-se as duas grandes áreas de estudo de qualidade de. software: Qualidade de Produto de Software e Qualidade de Processo de Software, sendo esse último desenvolvido com mais detalhes no capítulo seguinte.

\subsection{Visões Gerais de Qualidade}

Em diferentes situações, diferentes significados podem ser atribuídos ao termo Qualidade, de acordo com a opinião ou enfoque de quem faz uso. Existe uma grande contribuição técnica, de áreas aparentemente distintas como filosofia, administração ou engenharia, dedicadas ao estudo da questão de qualidade. Isso tem levado a uma considerável abrangência da noção do que seja qualidade, mas por outro lado, têm-se gerado confusões e equívocos quando se tenta colocar em prática essas definições diferentes [Paladini, 1990].

É importante ressaltar que o que existe de mais prejudicial em termos de definição equivocada são os resultados práticos decorrentes da má utilização do termo. Como exemplo podemos citar:

a) Pensa-se em qualidade como algo abstrato, sem vida própria, indefinido. Nesse sentido ela seria algo inatingível, que não pode ser medido e nem avaliado em uma base objetiva;

b) Identifica-se qualidade como perfeição, imaginando que seja um conceito definitivo e imutável. Assim, a qualidade reflete a situação de se ter atingido um patamar máximo não podendo mais ser alterada; 
c) Confunde-se ainda, qualidade com classe ou categoria de um produto. Se a qualidade é refletida em diferentes modelos, poderia se induzir a pensar que basta agregar novos componentes ao modelo para melhorar sua qualidade.

Para evitar essas decorrências, estudar os diferentes conceitos relacionados ao termo tem sido uma preocupação constante do pessoal envolvido com qualidade. Os diferentes enfoques sobre a questão são organizados de maneira a agrupar os conceitos em conjuntos específicos. Nesse sentido, tem-se destacado o trabalho do pesquisador americano David A. Gavin [Paladini, 1990].

A seguir, analisam-se cinco abordagens propostas por Garvin, publicadas em 1984 que proporcionam uma visão geral do conceito de qualidade em função da sua abrangência $e$ organização.

\section{a) Abordagem Transcendental}

Essa abordagem trata a qualidade como um conceito abstrato que dificilmente pode ser fixado com precisão. Nessa abordagem, qualidade representa uma característica, uma propriedade ou um estado que torna um produto ou senviço aceitável, embora essa aceitação não seja derivada de análise e estudo realizado, mas da constatação prática e da experiência. Como exemplo dessa abordagem, podemos considerar os atributos estéticos do ser humano. Eles são apenas obsenváveis, mas dificilmente podem ser descritos.

b) Abordagem Centrada no Produto

Essa abordagem entende qualidade como uma variável passível de medição precisa. Assim, diferenças de qualidade são obsenváveis no produto pela quantidade e diversidade de elementos ou atributos que o produto possui ou não. Isso traz uma contribuição relevante para a fixação de um conceito prático do que seja qualidade. Observa-se que, nesse caso, existe um modelo de avaliação da qualidade baseado em padrões objetivos, permitindo medir a qualidade de um modo livre de opiniões, preferencias ou pontos de vista, numa escala contínua e bem definida. Uma citação de Abbott (1955) que pode definir essa abordagem de qualidade é "Diferenças na qualidade equivale a diferenças da qualidade de alguns elementos ou atributos desejados". 


\section{c) Abordagem Centrada no Valor}

Essa abordagem agrega qualidade ao custo de produção. Considera que um produto é de boa qualidade se apresentar alto grau de conformidade aos requisitos do produto por um custo aceitável. Assim, um produto apresenta qualidade se oferecer melhor desempenho a um preço reduzido. Pode-se citar a frase de Feigenbaun (1961) como aplicação dessa abordagem, "Qualidade é o melhor possivel sob certas condlções do consumidor. Estas condições são referentes ao uso real e ao preço de venda do produto".

\section{d) Abordagem Centrada no Processo de Fabricação}

Essa abordagem fixa-se no esforço realizado em produzir um item de acordo com suas especificações básicas, determinadas durante o projeto. Assim, se o processo de fabricação não pode desenvolver um produto conforme suas especificações, automaticamente, a qualidade estará comprometida logo no primeiro esforço para produzí-lo. Como exemplo, pode-se apresentar a definição de qualidade na frase de Crosby (1979) "Qualidade é a conformidade do produto às suas especificaçōes".

\section{e) Abordagem Centrada no Usuário}

Essa abordagem concentra-se no usuário como fonte de toda a avaliação de qualidade de um produto. Primeiro define-se o que o consumidor deseja, e a partir daí, procura-se desenvolver um produto que esteja de acordo com as vontades do consumidor. Dessa forma, a qualidade de um produto fica condicionada ao grau com que ele atende às necessidades e conveniências do consumidor [Juran, 1970]. Como um exemplo prático dessa abordagem torna-se compreensível o fato de que produtos com ótimos projetos, bons padrōes de desempenho, bonitas embalagens, sem nenhum defeito aparente, saem das fábricas destinadas ao sucesso - na visão da empresa - e acabam não vendendo nada.

$O$ fato de existirem diversas abordagens e, conseqüentemente, muitos conceitos de qualidade, não constituem entrave à sua compreensão, embora isso cause alguns conflitos quando da sua aplicação. Porém, esses conflitos podem ser minimizados ao se analisar a questão globalmente, e nas várias fases de produção. Por exemplo, a abordagem centrada no produto fixa-se em aspectos como desempenho e durabilidade; a abordagem centrada no usuário preocupa-se com a estética e conveniência para o uso; já a abordagem centrada no processo de fabricação fixa-se em confiabilidade e conformidade. Assim, subjetivas ou não, mensuráveis ou não, as diversas características do produto precisam ser consideradas e as 
existências de diversas abordagens ressaltam a importância de uma análise global [Paladini, 1990].

\subsection{Qualidade Aplicada ao Software}

Devido a constante demanda de sistemas computacionais, gerada pela vida moderna, que cada vez mais passa a ter computadores integrados a sua rotina, esses sistemas computacionais vêm tendo um crescente aumento de complexidade.

Porém, desde os tempos remotos, muitos problemas no desenvolvimento dos sistemas computacionais já se faziam sentir, motivo pelo qual em 1968, o Comitê de Ciências da OTAN (Organização do Tratado do Atlântico Norte) reunlu 50 especialistas, cientistas e profissionais da indústria de software para discutir possíveis soluçōes para o que passou a ser conhecido como a Crise do Software [Oliveira, 1995].

Foi nesse encontro que se firmou o termo Engenharia de Software, e foi definida formalmente a necessidade da aplicação de uma abordagem sistemática, disciplinada $\Theta$ quantificável para o desenvolvimento, operação e manutenção de produtos de software. Observando a Engenharia de Software através de uma perspectiva histórica, a década de $60 \theta$ os anos que a antecedem podem ser chamados de Era Funcional, os anos 70 de Era do Método, os anos 80 como a Era do Custo e os anos 90 como a Era da Qualidade [Kan, 1995].

Nos anos 60, aprendeu-se a usar a tecnologia da informação para suprir as necessidades institucionais e começar a integrar o software nas operações diárias das instituiçōes.

Nos anos 70, como as organizaçōes de software foram caracterizadas por maciços atrasos nos planos e constantes ultrapassagens dos custos planejados, a maior preocupação nessa fase era planejar e controlar os projetos de software. Foi quando os modelos de ciclo-devida, baseados em várias fases, foram introduzidos e analisados.

Nos anos 80, o custo do hardware começou a cair e a tecnologia da informação se tornou acessível às pessoas, individualmente, nāo mais somente para as instituiçōes. A competição das indústrias tomou um rumo diferente, uma vez que aplicaçōes de baixo custo puderam ser largamente implementadas. Assim, a importância da produtividade no desenvolvimento de software aumentou significativamente. Nessa fase, vários modelos de 
custo na Engenharia de Software foram implementados e usados. E foi também no final dessa década que se reconheceu a importância da qualidade de software.

A década de 90 e os anos que seguem podem, certamente, ser chamados de Era da Qualidade. Com a tecnologia do estado da arte, espera-se atender a demanda dos clientes com a crescente exigência de alta qualidade. A exigência por qualidade é intensificada pela crescente dependência da sociedade pelo software. Do ponto de vista dos desenvolvedores de software, qualidade não é mais um fator de vantagem no mercado, mas uma condição necessária para que a organização possa continuar competindo com sucesso.

Qualidade é um termo que pode ter diferentes interpretaçōes. Para se estudar a qualidade de software de maneira efetiva é necessário, inicialmente, obter um consenso em relação à definição de qualidade que está sendo abordada.

Existem muitas definições de qualidade de software propostas na literatura, sob diferentes pontos de vistas. A seguir apresenta-se algumas:

"Um produto de software apresenta qualidade dependendo do grau de satisfação das necessidades dos clientes sob todos os aspectos do produto"[Sanders, 1994].

"Qualidade de software é o grau em que o software possui uma combinação desejada de atributos" [IEEE Std 729 - 1983].

"Qualidade de software é o grau em que os atributos do software são capazes de desempenhar sua finalidade especificada"[DOD - Std 2168].

"A percepção da qualidade de software é vista principalmente em termos de tempo em que um sistema de software opera corretamente"[Smith, 1989].

Para o propósito em questão, a definição de qualidade de software analisada com mais detalhes é a apresentada por Pressman (1994):

"Qualidade de software é a conformidade aos requisitos de desempenho e de funcionalidade que foram explicitamente definidos, aos padröes de desenvolvimento explicitamente documentados, e às características implícitas que são esperadas por todo software desenvolvido por profissionais". 
A definição acima enfatiza três aspectos importantes:

1. Requisitos de software são os fundamentos para medir qualidade, pois a falta de conformidade dos requisitos é falta de qualidade;

2. Padrões especificados definem um conjunto de critérios de desenvolvimento, que auxilia o gerente a guiar a confecção do software. Se o critério não é rigoroso, resulta-se na falta de qualidade do produto;

3. Existe um conjunto de requisitos implícitos que muitas vezes não é mencionado na especificação. Se o software atende aos requisitos explícitos, mas falha nos requisitos implícitos, a qualidade do software pode ser comprometida.

Dos requisitos do usuário à entrega do produto final, existe um processo de desenvolvimento que é complexo e freqüentemente envolve uma série de estágios que podem comprometer a qualidade do produto final.

Em cada fase do processo de desenvolvimento, um produto intermediário é produzido para um usuário intermediário - a próxima fase. Se esse produto intermediário, de alguma forma, não satisfaz aos requisitos do usuário ou algum requisito implícito, ele irá comprometer a qualidade do produto dessa fase. Portanto, cada produto intermediário tem certos atributos de qualidade que afetam a qualidade do produto intermediário da próxima fase e assim, afetam a qualidade do produto final [Kan, 1995].

Um processo bem estabelecido, compreendido e controlado pode ajudar a alcançar a obtenção de qualidade do produto, desde que sejam definidos claramente os requisitos de qualidade desse produto. Assim, pode-se definir a qualidade de software pela ótica do usuário como sendo a conformidade aos requisitos estabelecidos [Andrade, 1996].

Existe, ainda, uma visão de qualidade de software através da ótica do desenvolvedor. Nessa visão, um software de fácil manutenção e fácil de testar pode ser considerado um software de qualidade. Já do ponto de vista gerencial, o software que possa ser desenvolvido com baixo custo pode ser um software de alta qualidade. Isso demonstra que, ainda dentro da qualidade de software, pode-se definir várias visöes diferentes, como tem sido para a definição da qualidade como um termo geral [Gillies, 1993].

O estudo de qualidade de software tem sido realizado, dividindo-se qualidade de software em duas grandes áreas: a qualidade do produto de software e a qualidade de processo de software. 


\subsubsection{Qualidade de Produto de Software}

Todo o esforço, inicialmente, estava concentrado em se obter controle da qualidade do produto final para que um produto defeituoso não chegasse às mãos do cliente. Dentro do estudo da qualidade de software essa abordagem é conhecida como Qualidade de Produto de Software.

Esforços apresentados por McCall (1977) e explicitados na norma ISO/IEC 9126 (1994) procuram definir um conjunto de fatores ou características que evidenciam a qualidade do produto final [Cavano, 1978].

Essas características são definidas para representar necessidades $\theta$ desejos daqueles que estão envolvidos direta ou indiretamente com o software [Tsukumoto, 1995]. Isso significa que as necessidades dos envolvidos, direta ou indiretamente, com o software devem ser mapeados como características que o produto de software deve possuir.

O esforço pela padronização mundial para se definir qualidade de produto de software pode ser sentido pela norma ISO/IEC 9126, que foi publicada em 1991 e é uma das mais antigas da área de qualidade de software. Essa norma já possui sua tradução para o Brasil, publicada em agosto de 1996 como NBR 13596.

Essas normas listam o conjunto de características que deve ser verificado em um software para que ele seja considerado um "software de qualidade". Essas características são divididas em seis grandes grupos, cada um, por sua vez, dividido em algumas subcaracterísticas [ISO/IEC 9126, 1994].

Essas características e subcaracterísticas estão relacionadas no Quadro 2.1.

\subsubsection{Qualidade de Processo de Software}

O estudo da qualidade de processo de software tem concentrado seus esforços na organização de um grupo que seja capaz de desenvolver o software dentro dos limites de tempo, custo e estimativas planejados. Para Isso, um mecanismo gerencial deve garantir 0 cumprimento das responsabilidades e a condução do grupo em alguma situação imprevista, enfim deve permitir que $\circ$ grupo possa desenvolver o sistema de maneira segura e controlada [Kan, 1995]. 


\begin{tabular}{|c|c|c|}
\hline 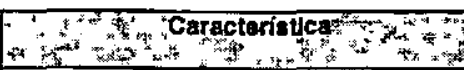 & Wobcaractoristcat & 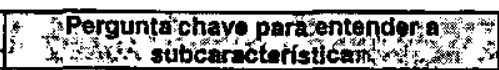 \\
\hline \multirow[b]{5}{*}{$\begin{array}{c}\text { Funcionalidade } \\
\text { (satlsfaz as necessidades?) }\end{array}$} & Adequaçăo & Propöo-sa a fazer o que é apropriado? \\
\hline & Acurácia & Faz o que foi proposto de forma correta? \\
\hline & interoperbilidado & Interage com os sistemes aspacificados? \\
\hline & Conformidade & Está de acondo com as nomas, leis, etc.? \\
\hline & Segurança de acesso & Evita acesso nāo autorizado aos dados? \\
\hline \multirow{3}{*}{$\begin{array}{l}\text { Confiabilidade } \\
\text { (é imune a faihas?) }\end{array}$} & Maturidade & Com que freqũêncie apresenta falhas? \\
\hline & Tolerâncla a falhas & Ocorrendo falhas, como ala reage? \\
\hline & Recuperabilidade & $\begin{array}{c}\text { E capaz de recuperar dados em caso de } \\
\text { teiha? }\end{array}$ \\
\hline \multirow{3}{*}{$\begin{array}{l}\text { Usabilidade } \\
\text { (é fácil de usar?) }\end{array}$} & Inteiegibilidade & É fácil entender o conceito e a apilcaçāo? \\
\hline & Apreensibilidade & Éácil aprender a usar? \\
\hline & Operacionalidade & E fácil de operar e controlar? \\
\hline \multirow{2}{*}{$\begin{array}{l}\text { Eficiência } \\
\text { (é rápido e enxuto?) }\end{array}$} & Tempo & $\begin{array}{l}\text { Qual é o tempo de resposta a valocidade } \\
\text { de execucão? }\end{array}$ \\
\hline & Recursos & $\begin{array}{l}\text { Quanto recurso usa? } \\
\text { Durante quento tempo? }\end{array}$ \\
\hline \multirow{4}{*}{$\begin{array}{l}\text { Manutenibilidade } \\
\text { (é fácil de modiffcar?) }\end{array}$} & Analisabilidede & $\begin{array}{c}\text { Écicil de encontrar uma falha, quando } \\
\text { ocorre? }\end{array}$ \\
\hline & Modfificabilidade & E fácil modificar e adaptar? \\
\hline & Estabilidade & Há grande risco quando se taz aiteraçōes? \\
\hline & Testabilidade & E fácil testar quando se faz alteraçöes? \\
\hline \multirow{4}{*}{$\begin{array}{l}\text { Portabilidade } \\
\text { (é fácil de usar em outro ambiente?) }\end{array}$} & Adaptabilidade & E fácil adaptar a outros ambientes? \\
\hline & Capacidade. para ser instalado & E fácil instajar em outros ambientes? \\
\hline & Conformidade & $\begin{array}{l}\text { Está de acordo com padróes de } \\
\text { portabilidade? }\end{array}$ \\
\hline & Capacidade para substituir & E fácil usar para substitutir outro? \\
\hline
\end{tabular}

Quadro 2.1:Características e Subcaracterísticas da norma ISO/IEC 9126 (1994)

Essa abordagem é desenvolvida com mais detalhes no capftulo seguinte, uma vez que é de extrema importância apresentar esse contexto, pois é o panorama em que se encontra o trabalho desenvolvido.

\subsection{Considerações Finais}

Neste capítulo foram apresentados os conceitos gerais de qualidade e de qualidade de software utilizado para a contextualização do trabalho. Algumas definições foram apresentadas e uma ênfase maior foi dada à divisão dos estudos de qualidade de software: Qualidade de Produto de Software e de Qualidade de Processo de Software, sendo esse último, desenvolvido com mais detalhes no capítulo seguinte. 


\section{Capítulo 3 - Qualidade de Processo de Software}

\subsection{Considerações Iniciais}

Neste capítulo, desenvolve-se mais detalhadamente o estudo da Qualidade de Processo de Software. Conceitos como processo de software e modelos de processos de software são definidos. O modelo de processo de software CMM é descrito com maiores detalhes, pois é o modelo escolhido para a realização deste trabalho.

\subsection{O Processo de Software}

O Processo de Software consiste em uma série de atividades, políticas, práticas, eventos, ferramentas e métodos que garantem, técnica e administrativamente que o software possa ser desenvolvido de maneira organizada, disciplinada e previsível. O Processo de software é representado por um conjunto seqüencial de atividades, objetivos, transformaçōes e eventos que encapsulam estratégias para cumprimento dáevolução do software [Paulk, 1993].

Para que o processo de software seja efetivo para o cumprimento dos seus objetivos, é necessário um planejamento detalhado que releve a realidade do ambiente de desenvolvimento de software. Deve-se considerar aspectos especificos do projeto como metas e políticas, equipe de desenvolvimento, cronograma do projeto, disponibilidade de recursos humanos, técnicos, e outros. Além desses aspectos, existem outros que também devem ser relacionados ao processo como: fluxo de informação através das fases do processo, condiçōes específicas para delimitar o início e o fim de cada fase, paralelismo, seqüenciamento das atividades, papéis desempenhados pelas pessoas no processo, interface entre o processo e as ferramentas e outros [Marciniat, 1994].

A Figura 3.1 representa o processo de software com todos os elementos que envolvem o processo de desenvolvimento de software (parte técnica do processo). 


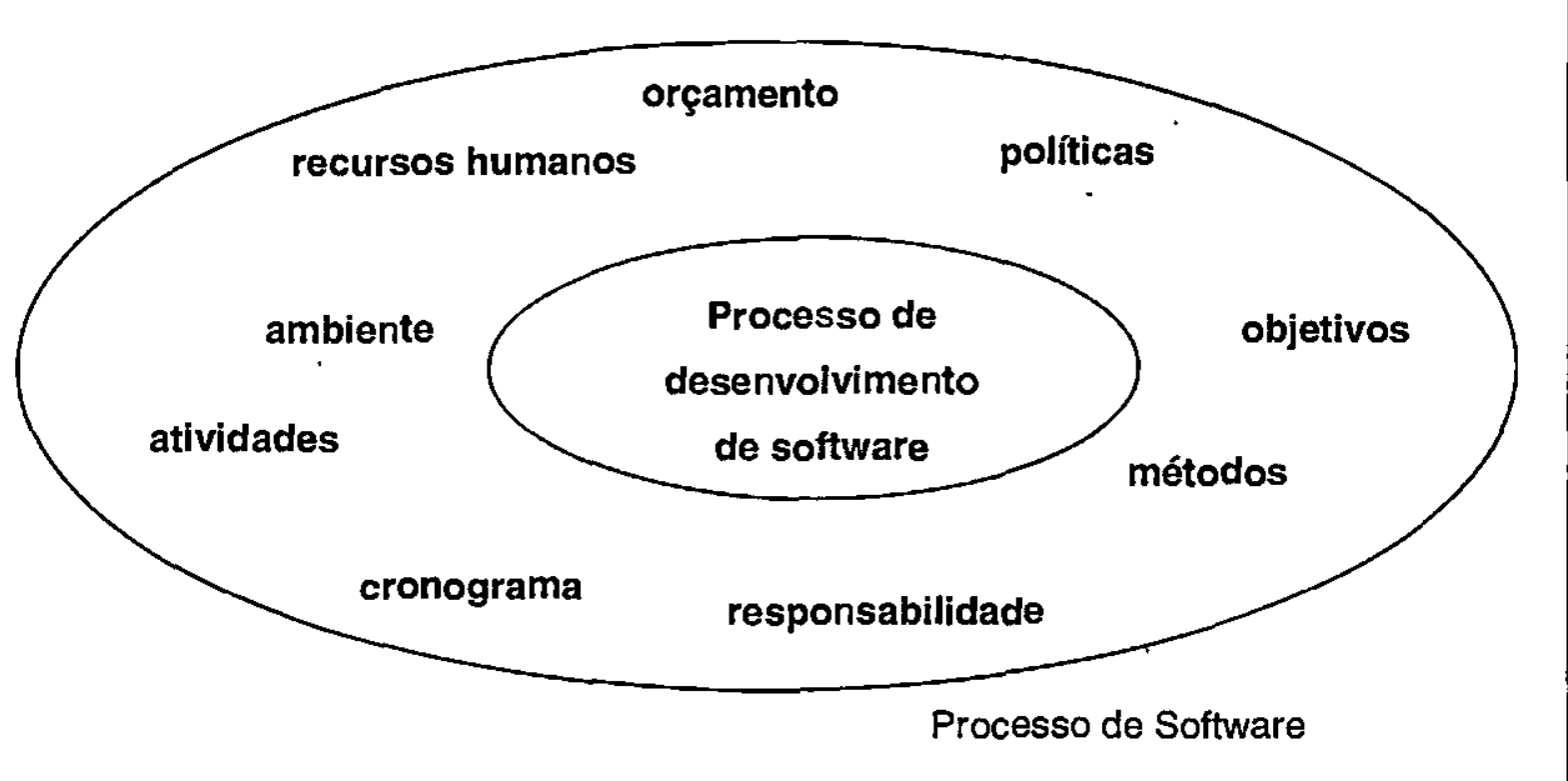

Figura 3.1: O Processo de Software

Por isso, estudos mais recentes de qualidade propõem um controle sobre o processo de software. Isso implica que o software deve ser desenvolvido por um processo que garanta que - mesmo seja produzido de acordo com os padrões de qualidade impostos pelos termos do contrato [Garmus, 1996].

A grande importância dada ao processo de software pode ser vista como forma de se garantir a construção de um software de melhor qualidade. Espera-se que um processo de software controlado propicie segurança frente às variações que o produto possa sofrer em relação às suas especificações iniciais [Smith, 1989]. Nesse contexto pode-se incluir ainda a necessidade de se cumprir um cronograma e possuir um orçamento limitado, fazendo com que a produtividade seja um fator decisivo para o cumprimento efetivo dos objetivos de se construir um. software.

Um ambiente com essas características deve fornecer também métodos e ferramentas para planejar, executar e mudar os processos, considerando as necessidades em questāo e suas restriçōes. Sendo assim, haverá um controle explícito de qualidade, orçamento e cronograma referentes ao sistema em desenvolvimento [Madhavji, 1991]. 


\subsection{Modelo de Processo de Software}

Como é intensa a dinâmica que rege o processo de software, gerenciá-lo se toma uma tarefa difícil. Para tanto, descrever e definir modelo de processo de software se faz necessário [Oliveira, 1995]. Esse modelo de processo de software permite definir, executar e controlar adequadamente as atividades de desenvolvimento de software, abrangendo pessoas e suas responsabilidades, recursos, cronogramas, orçamentos, o processo de desenvolvimento em si, técnicas, métodos, ferramentas e outros elementos.

Outro aspecto importante do modelo de processo de software $\theta$ que esse tenha alto grau de flexibilidade, pois sempre existe uma constante pressāo para melhorias. Existem certas diretrizes que devem ser seguidas para que se possa melhorar o processo sob controle, dentre elas temos: medir aspectos quantitativos e qualitativos do processo, além de se ter a visāo do impacto que a mudança para a meihoria pode causar [Humphrey, 1989]

Vários modelos de processos de software sāo propostos na literatura, dentre eies, podemos citar:

- CMM (Capability Maturity Model): modelo proposto pelo Software Engineering Institute (SEI) [SEI, 1997];

- SPICE (Software Process Improvement and Capability dEtermination) parte 2: Modelo para Gerenciamento de Projetos: desenvolvido pela International Organization for Standardization (ISO15504-2) [SPICE1, 1997];

- Trillium: modelo proposto pela Bell Canada [Coallier, 1994].

Entre os modelos de processos que são propostos em âmbito mundial, sem dúvida, o CMM tem se mostrado uma referência muito valiosa para a evoiução da maturidade dos processos [Arruda, 1998] e é por isso, o modelo escolhido para realização deste trabalho. Na próxima seção é apresentado com mais detalhe, o Modelo CMM.

\subsection{O Modelo CMM (Capability Maturity Model)}

O CMM desenvolvido pela SEI (Software Engineering Institute), tem como princípio básico, medir. a maturidade do processo de software de uma organizaçāo. Apresenta um modelo que apoia a melhorla do processo de software de uma organização através da 
aplicação criteriosa de conceitos de gerenciamento de processo e de melhoria de qualidade do desenvolvimento $\Theta$ manutençăo de software [Marciniat, 1994].

O modelo CMM classifica as organizações em cinco níveis de maturidade. Essa classificação significa que a organização de software cumpre certos conjuntos de atividades denominados áreas-chave de processo que são exigidos em cada nível [Grady, 1997].

Cada nível de maturidade focaliza aspectos específicos do processo de software. No nível 1, o foco está na coragem e competência das pessoas. No nível 2 , o foco está no processo de gerenciamento de projetos. No nível 3, o foco está no processo de engenharia e suporte organizacional. No nível 4, o foco está na qualidade de produto e de processo. E, finalmente, no nível 5, o foco é o processo de melhoria contínua. O Quadro 3.1 apresenta os níveis de maturidade com seus respectivos focos e suas áreas-chave.

\subsubsection{Nível 1 de Maturidade: Inicial}

Também conhecido como nível Caótico ou Ad Hoc de maturidade. É caracterizado pela falta de planejamento e estimativas de custo e pela falta de procedimentos formalizados. Mesmo que a organização possua procedimentos formalizados, a falta de mecanismos gerenciais para garantir o andamento do processo, acaba comprometendo os procedimentos estabelecidos. Nesse nível, o sucesso do projeto depende, praticamente, da competência dos indivíduos envolvidos no processo de desenvolvimento.

A principal característica de organizações nesse nível é que se encontram numa situação imprevisível, tanto para o sucesso quanto para o fracasso. Os maiores problemas com os quais essas organizações de software se defrontam são gerenciais e não técnicos. Nesse nível, as organizaçōes não possuem áreas-chave de processo.

Organizações nesse nivel de maturidade podem melhorar seu desempenho instituindo controles básicos para o projeto, como por exemplo, uma gerência que assuma de maneira efetiva todos os compromissos e consiga dar andamento segundo as diretrizes especificadas.

Deve ser criado um grupo de controle para garantir que se possa realizar o planejamento, o monitoramento, a implementação e a verificação das atividades. Esse grupo deve controlar, de maneira efetiva, as possiveis alteraçōes que possam ocorrer no planejamento e deve ter controle da parte gerencial. 


\begin{tabular}{|c|c|c|}
\hline Nível & Foco & Áreas-chaves \\
\hline $\begin{array}{c}5 \\
\text { Otimizaçāo }\end{array}$ & Processo de Melhoria Contínua & $\begin{array}{l}\text { Prevenção de Defeitos } \\
\text { Gerenciamento de Mudança de Tecnologia } \\
\text { Gerenciamento de Mudança de Processo }\end{array}$ \\
\hline $\begin{array}{c}4 \\
\text { Gerenciado }\end{array}$ & Qualidade de Produto e de Processo & $\begin{array}{l}\text { Gerenciamento Quantitativo do Processo } \\
\text { Gerenciamento de Qualidade de Software }\end{array}$ \\
\hline $\begin{array}{c}3 \\
\text { Definido }\end{array}$ & $\begin{array}{c}\text { Processo de Engenharia e Suporte } \\
\text { Organizacional }\end{array}$ & $\begin{array}{l}\text { Foco no Processo da Organização } \\
\text { Definição do Processo da Organização } \\
\text { Programa de Treinamento } \\
\text { Gerenciamento de Software Integrado } \\
\text { Engenharia de Produto de Software } \\
\text { Coordenação de Intergrupos } \\
\text { Revisōes }\end{array}$ \\
\hline $\begin{array}{c}2 \\
\text { Repetíve! }\end{array}$ & $\begin{array}{c}\text { Processos de Gerenciamento de } \\
\text { Projeto }\end{array}$ & $\begin{array}{l}\text { Gerenciamento de Requisitos } \\
\text { Planejamento do Projeto de Software } \\
\text { Acompanhamento e Supervisão do Projeto de } \\
\text { Software } \\
\text { Gerenciamento de Subcontratos de Software } \\
\text { Garantia de Qualidade de Software } \\
\text { Gerenciamento de Configuração de Software }\end{array}$ \\
\hline $\begin{array}{c}1 \\
\text { Inicia! }\end{array}$ & Pessoas Competentes $\theta$ Heróicas & \\
\hline
\end{tabular}

Quadro 3.1: O Modelo CMM [Paulk, 1995]

\subsubsection{Nível 2 de Maturidade: Repetível}

A grande diferença, desse estágio para o anterior, é de que o processo tem como fundamento 0 controle dos procedimentos planejados, o controle dos compromissos e de outras atlvidades. Esses controles são realizados através de procedimentos gerenciais de processos de desenvolvimento de software.

Através de procedimentos formals estabelece-se uma política de gerenciamento de projeto de software, desde gerenciamento de requisitos e controle de produtos intermediários até o cumprimento dos padrões de projetos definidos pela organização.

Com o planejamento e a garantia do cumprimento dos procedimentos formais, os projetos podem obter constantes sucessos e toda essa metodologia de desenvolvimento pode ser assimilada e aplicada a projetos similares. 
Nesse nível, uma organização é caracterizada pela presença das seguintes áreaschave de processo [Paulk, 1993]:

Gerenciamento de Requisitos: a finalidade dessa área-chave é estabelecer um entendimento comum entre cliente e a equipe do projeto, sobre os requisitos do software que serão abordados. Isso envolve documentar e controlar os requisitos do cliente e manter os planos, produtos e atividades consistentes com esses requisitos.

Planejamento de Projeto de Software: a finalidade dessa área-chave é estabelecer planos razoáveis para desenvolver e gerenciar o processo de software. Isso envolve desenvolver estimativas, determinar os compromissos $\theta$ definir um plano para realizar o trabalho. Esse plano deve conter o ciclo de vida do projeto de software, uma lista de produtos a serem entregues ao cliente, prazos, estimativas para o nível de esforço, recursos, ferramentas de suporte e riscos do projeto.

Acompanhamento e Supervisão do Projeto de Software: a finalidade dessa área-chave é oferecer visibilidade adequada do progresso real do projeto, para que a gerência possa tomar medidas efetivas quando o desempenho do projeto se desvia significativamente do plano. Isso envolve acompanhar e revisar os resultados $\theta$ as realizações do software confrontando com as estimativas documentadas, compromissos e planos. Envolve, também, ajustar os planos com base nos resultados e realizações efetivamente alcançados. Os mecanismos utilizados são revisōes internas e revisōes formais com clientes. Quando ocorre um desvio entre os planos e os resultados efetivos, deve-se alterar a forma como o trabalho está sendo feita e/ou ajustar os planos.

Gerenciamento de Subcontrato de Software: a finalidade dessa área-chave é selecionar fornecedores (que se responsabilizam por parte do trabalho) qualificados $\theta$ gerenciá-los eficazmente. Isso envolve selecionar o fornecedor, estabelecer compromissos, acompanhar $e$ revisar o desempenho e os resultados obtidos. Na seleção e gerenciamento do fornecedor são necessários documentos como: cláusula de contrato, requisitos do projeto, produtos a serem entregues, padrōes e procedimentos a serem seguidos.

Garantia de Qualidade de Software: a finalidade dessa área-chave é oferecer gerenciamento, com visibilidade apropriada, do processo que está sendo utilizado e dos produtos que estão sendo desenvolvidos. Isso envolve revisões e auditorias nos produtos de software e nas atividades para assegurar que estão em conformidade com os padrōes e 
procedimentos aplicados. Envolve também fornecer esses resultados para os gerentes envolvidos.

Gerenciamento de Configuração do Software: a finalidade dessa área-chave é estabelecer e manter a integridade dos produtos do projeto de software ao longo do ciclo de vida do software. Isso envolve identificar os itens de configuração, controlar sistematicamente as alterações e manter a integridade da configuração ao longo do ciclo de vida do software. $O$ gerenciamento da configuração utiliza linhas de referência (baselines) que servem como um marco no ciclo de vida do software. Os itens que passam por uma linha de referência podem ser alterados somente através de procedimentos formais de controle de mudanças.

Para que as organizações que se encontram nesse nível apresentem melhoras rumo ao próximo nível, deve-se estabelecer um grupo de processo que deve ter como principal objetivo a melhoria do processo de software. O grupo deve agir diretamente sobre objetivos como definir formalmente o processo de desenvolvimento, identificar oportunidades e necessidades de ferramentas e outros métodos, acompanhar o projeto e auxiliar a conduzir a gerência e o desempenho.

Se a organização já possuir métodos de engenharia de software tais como definição de ciclo de vida de software e outras atividades técnicas, deve-se estabelecer uma gerência para garantir o cumprimento efetivo dessas formalidades.

\subsubsection{Nível 3 de Maturidade: Definido}

O foco no nivel 2 se encontra nos projetos, já no nível 3 a ênfase é dada à organização. Isso significa que o nível 3 é caracterizado pela presença de um grupo, dentro da organização, responsável pelas atividades do processo de software. Esse grupo garante que os procedimentos de gerência e de desenvolvimento sejam bem definidos, documentados, compreendidos e integrados, e também garante que as saídas de uma atividade fluam naturalmente para as entradas da próxima atividade.

Outra característica desse estágio é que a organização oferece programas de treinamento para garantir a integridade dos objetivos entre a gerência e o grupo de desenvolvimento, e para amenizar qualquer crise gerada pela mudança no processo. Isso é muito importante, uma vez que processos definidos pela própria organização são caracterizados por constantes modificaçōes nos fundamentos do processo estabelecido. 
Todas essas características podem auxiliar a organização no sentido de valer-se de um processo previamente definido ou adaptado e com uma certa preparação da equipe, como um todo, diante de um novo desafio que a organização possa vir a enfrentar.

Organizações nesse nível são caracterizadas pela presença das seguintes áreas-chave de processo [Paulk, 1993]:

Foco no Processo da Organização: a finalidade dessa área-chave é determinar a responsabilidade organizacional para as atividades de software que melhoram a capacidade do processo de software como um todo na organização. Isso envolve desenvolver e manter a compreensão dos processos de software da organização e coordenar as atividades de avaliação, desenvolvimento, manutenção e melhoria desses processos. Uma forma típica de se dirigir o foco é manter um grupo de processo dentro da organização que será responsável por estabelecer um padrão de processo, manter uma base de dados, oferecer educação, e consultoria, e realizar avaliações periódicas para gerar relatórios sobre a situação real do processo.

Definição do Processo da Organização: a finalidade dessa área-chave é desenvolver e manter um conjunto de bens de processo de software que melhore o desempenho do processo e ofereça uma base para benefícios cumulativos e de longo prazo. As atividades dessa áreachave podem ser mantidas por uma organização para uso dos projetos de desenvolvimento, adaptação, manutenção e implementação das práticas de software. Os bens de processo sāo: o processo de software padrão da organização, um conjunto de descrições de ciclos de vida em uso, as diretrizes e os critérios adotados para o processo de software em uso, uma base de dados e uma biblioteca de documentação de assuntos relacionados ao processo de software.

Programa de Treinamento: a finalidade dessa área-chave é desenvolver as habilidades pessoais da organização e aumentar o conhecimento dos indivíduos para que eles possam desempenhar seus papéis ou funções de maneira eficiente. Isso envolve identificar as necessidades de treinamento dentro da organização para os projetos e desenvolver e/ou contratar treinamento para preencher essas necessidades.

Gerenciamento de Software Integrado: a finalidade dessa área-chave é integrar a engenharia de software do projeto às atividades de gerenciamento em um processo de software definido e coerente. Isso envolve desenvolver um processo de software definido adaptando o processo de software padrão da organização e gerenciando o projeto de software 
de acordo com esse processo de software definido, pois no nivel 3, cada projeto adapta o processo de software padrão da organização às suas necessidades particulares.

Engenharia de Produto de Software: a finalidade dessa área-chave é estabelecer, de maneira consistente, um processo de engenharia bem definido que integre todas as atividades de engenharia de software para produzir, de forma eficiente, produtos de software consistentes $\theta$ adequados. Isso envolve desempenhar as tarefas de engenharia como definir o ciclo de vida para construir e manter software utilizando ferramentas e métodos adequados. Um ciclo de vida de software corresponde à execução de várias atividades de desenvolvimento como análise dos requisitos, projeto de software, codificação, teste e manutenção. Todas essas atividades devem ser devidamente documentadas.

Coordenação Intergrupos: a finalidade dessa área-chave é estabelecer meios para que o grupo de engenharia de software interaja ativamente com outros grupos, a fim de que o projeto possa satisfazer eficientemente as necessidades dos clientes. Isso envolve uma interação disciplinada $\theta$ uma coordenação dos grupos de engenharia de projeto para que sejam abordados requisitos em nível de sistema, objetivos e planos. Exemplos de grupos que precisam se inter-relacionar numa organização são: marketing, treinamento, gerenciamento de subfornecedores e outros.

Revisões: a finalidade dessa área-chave é remover com antecedência e eficientemente os defeitos dos produtos obtidos durante o desenvolvimento de software (produtos intermediários). Isso envolve um exame metódico desse produto para identificar defeitos e áreas onde mudanças são necessárias. Métodos alternativos de revisōes são inspeçōes, "walkthroughs" e outros.

Para se preparar para o nível seguinte, a organização deve se conscientizar de que nesse nível, qualquer informação documentada é qualitativa, $\theta$ para identificar parâmetros de custo e qualidade com maior precisāo, deve ser estabelecido um conjunto de medidas de processo.

Além disso, as informações de cada etapa do processo devem ser gerenciadas de maneira organizada, através de um sistema de banco de dados, para que as informaçōes possam ser analisadas e estejam disponíveis para constantes avaliaçōes. Essas avaliações podem, por exemplo, localizar a etapa em que o processo não está atendendo o nível de qualidade estabelecida. 


\subsubsection{Nível 4 de Maturidade: Gerenciado}

Nesse nível encontram-se as organizações que definem quantitativamente os objetivos de qualidade, através de medidas bem definidas e consistentes. Essas medidas são usadas como instrumento para prevenção e realização de melhoria no processo.

Uma organização nesse estágio deve possuir também um sistema de banco de dados para armazenar, controlar $\theta$ analisar parâmetros de qualidade definidos no processo. Através da utilização desses dados, pode-se prevenir problemas futuros no processo, melhorar a eficiência e realizar uma análise minuciosa da atual situação da organização diante de um desafio.

Organizações nesse nível são caracterizadas pela presença das seguintes áreas-chave de processo [Paulk, 1993]:

Gerenciamento Quantitativo do Processo: a finalidade dessa área-chave é controlar de maneira quantitativa o desempenho do processo de software. Isso envolve determinar metas para o desempenho do processo, medir esse desempenho, analisar as medições $\theta$ fazer ajustes para manter o desempenho do processo dentro de limites aceitáveis. Controle quantitativo significa usar técnicas quantitativas ou baseadas em métodos estatísticos. Essas técnicas requerem dados mensuráveis, levantamento de dados consistentes e medições definidas e comparáveis. Algumas ferramentas básicas para controle estatísticos são: histogramas, diagramas de causa e efeito, gráficos, diagramas de controle e outros.

Gerenciamento de Qualidade de Software: a finalidade dessa área-chave é desenvolver uma compreensāo quantitativa dos produtos de software do projeto e alcançar metas específicas de qualidade. Isso envolve definir metas de qualidade para produtos de software, determinar planos para alcançar essas metas e monitorar e ajustar os planos de software, produtos intermediários e metas de qualidade para satisfazer as necessidades $\theta$ desejos do cliente/usuário final.

Um dos maiores problemas que pode surgir nesse estágio é o custo na coleta e análise dos dados. Para enfrentar este problema, devem ser definidos, cuidadosamente, os dados que são considerados relevantes à análise que se deseja realizar. 


\subsubsection{Nível 5 de Maturidade: Otlmizado}

No nível mais alto de maturidade, a organização possui uma base quantitativa bem definida, que permite um investimento contínuo no processo de melhoria e de automação de procedimentos.

Devido ao grande volume de dados coletados durante todos os níveis anteriores, podese abstrair ganhos com produtividade e qualidade decorrentes do bom ajuste do processo. Com a efetividade do processo, pode-se analisar custo-benefício de novas tecnologias $\theta$ possuir uma base mais sólida para gerenciar mudanças no processo. Com a demonstração da efetividade do processo aplicado a qualquer produto, passa-se a ter confiança na qualidade do produto resultante.

Organizações nesse nível são caracterizadas pela presença das seguintes áreas-chave de processo [Paulk, 1993]:

Prevenção de Defeitos: a finalidade dessa área-chave é identificar a causa de defeitos e evitar que eles se repitam. Isso envolve analisar defeitos que foram encontrados no passado $\theta$ realizar açōes especificas para evitar ocorrências desse tipo de defeitos no futuro. $O$ foco deve ser a análise das causas, isto é, analisar o que no processo permitiu que o defeito ocorresse e o que necessita ser corrigido para prevenir a ocorrência de defeitos no futuro.

Gerenciamento de Mudança de Tecnologia: a finalidade dessa área-chave é identificar novas tecnologias (ferramentas, métodos e processos) e transferílas para a organizaçāo de uma forma orientada. Isso envolve tanto a identificação, seleção e avaliação de novas tecnologias quanto à incorporaçāo dessas novas tecnologias de maneira efetiva na organização.

Gerenciamento de Mudança de Processo: a finalidade dessa área-chave é melhorar continuamente os processos de software utilizados na organização, com o objetivo de melhorar a qualidade de software, aumentando a produtividade e diminuindo o tempo de ciclo para o desenvolvimento do produto. Isso envolve a definição de metas de melhoria do processo e a identificaçāo, avaliaçāo e implementação sistemática de melhoria no processo de software padrāo da organização e nos processos definidos no projeto. 
O nível 5 não é o destino final e sim uma base para construir a capacidade de se estar sempre em aperfeiçoamento.

O CMM apresenta um modelo de processo de software que deve ser implantado visando a melhoria contínua da organização. A implantação das áreas-chave de cada nível deve seguir às, necessidades da organização segundo a situação real do processo de software já existente e executado.

\subsection{Considerações Finais}

Neste capítulo, foi realizado um estudo mais detalhado de Qualidade de Processo de Software. O modelo de processo de software CMM é descrito com maiores detalhes, pois é o modelo escoihido para a realização deste trabalho.

No próximo capítulo, o contexto de melhoria de processo de software é abordado com mais ênf̣ase. 


\section{Capítulo 4 - Melhoria de Processo de Software}

\subsection{Considerações Iniciais}

Neste capítulo é descrito, com mais detalhes, o contexto de melhoria de processo. Para isso, são abordados dois modelos, entre vários citados pela literatura. O primeiro é o modelo PDCA, aplicável a qualquer tipo de processo, o mais antigo e o mais utilizado até hoje. Além desse, é apresentado o modelo IDEAL, desenvolvido especificamente para processo de software. Entre os dois modelos, o modelo escolhido neste trabalho, para ser utilizado como abordagem de melhoria de processo, é o modelo IDEAL, proposto pela SEI, pois o mesmo é baseado nas experiências obtidas com a implantação do modelo CMM.

Ainda neste capítulo, apresenta-se o modelo CAF (CMM Appraisal Framework) produzido, também pela SEl, para cumprir as tarefas de Diagnóstico do modelo IDEAL. O CAF representa uma série de diretrizes que devem ser seguidas para realizar uma avaliação baseada no CMM.

\subsection{Problemas de Empresas que Desenvolvem Software}

Após décadas de promessas não cumpridas totalmente, sobre ganhos na produtividade e qualidade, pela aplicação de novas tecnologias e metodologias de software, as organizaçōes industriais e governamentais estão concluindo que seus problemas fundamentais estão na inabilidade em gerenciar o processo de software.

Os benefícios de melhores métodos e ferramentas nāo podem ser sentidos na confusão de um projeto indisciplinado e caótico. Em muitas organizaçōes, geralmente, os projetos estão excessivamente atrasados e no dobro do valor orçado. Em tais casos, a organização, freqüentemente, năo estāo fornecendo a infra-estrutura e o suporte necessário para auxiliar os projetos a evitarem esses problemas.

Mesmo em organizaçōes indisciplinadas, entretanto, alguns projetos de software individuais produzem excelentes resultados. Quando isso acontece, é geralmente devido aos esforços de uma equipe dedicada. Na ausência de um processo de software para toda a organização, a repetição dos resultados depende exclusivamente de se ter os mesmos indivíduos disponíveis para o próximo projeto. 
Por isso, estudos mais recentes de qualidade propõem um controle sobre o processo de software. Isso implica que o software deve ser desenvolvido por um processo que garanta que o mesmo seja produzido de acordo com os padrões de qualidade impostos pelos termos do contrato [SPICE7, 1997].

A grande importância dada ao processo de software pode ser vista como forma de se garantir a construção de um software de melhor qualidade. Espera-se que um processo de software controlado propicie segurança frente às variações que o produto possa sofrer em relação às suas especificações iniciais. Nesse contexto, pode-se incluir ainda, a necessidade de se cumprir um cronograma e possuir um orçamento limitado, fazendo com que a produtividade seja um fator decisivo para o cumprimento efetivo dos objetivos de se construir um software [Kan, 1997].

Nesse contexto de controle de processo de software, procurando aperfeiçoar o ambiente de desenvolvimento de software, é que se insere a importância de se implantar melhoria de processo de software.

\subsection{Estratégias de Melhoria de Processo de Software}

Para se obter qualidade em um processo de software, é importante que as tarefas, responsabilidades, atividades, funções, recursos e pessoas que farão parte do processo de software a ser adotado sejam estudados, preparados e planejados com antecedência.

Para isso, é necessário o estabelecimento de uma estratégia para melhoria de processo de software, através da qual todos os elementos envolvidos no processo de software possam ser definidos e executados. Essa estratégia deve definir, como e quando as atividades de melhoria serão efetuadas, os responsáveis por elas e que recursos serão necessários.

A implantação de uma estratégia inicia-se com a definição de um plano de ação para controlar: os passos, a definição das atividades e o acompanhamento da implantação. $O$ plano deve ser suficientemente genérico para acomodar as peculiaridades de cada empresa, permitindo adequar as metas e soluções alternativas, específicas a cada ambiente [Pacheco, 1997]. 
Ao iniciar o desenvolvimento de uma estratégia de melhoria, é natural a dúvida sobre como e por onde começar e qual a forma mais adequada de apresentação das informações. É recomendado que sejam estudadas estratégias de melhoria que estão sendo adotadas por organizaçōes com os mesmos propósitos, e que tenham maior compatibilidade com o projeto para o qual a estratégia esteja sendo definida [Buckley, 1993].

Nesse contexto, existem modelos de melhoria contínua de processo. Dentre eles podemos citar:

- Ciclo PDCA (Plan-Do-Check-Act): conceitos originalmente desenvolvidos por Walter Shewart e popularizado mais tarde por W. Eduard Deming [Werkema, 1995];

- Modelo IDEAL (Initiating, Diagnosing, Establishing, Acting, Learning): desenvolvido pela Software Engineering Institute (SEI) [Gremba, 1998].

Os dois modelos de melhoria de processo de software são descritos detalhadamente nas seçōes que seguem.

\subsubsection{O Ciclo PDCA (Plan Do Check Act)}

O ciclo PDCA é um método gerencial de tomada de decisões para garantir o alcance das metas necessárias à sobrevivência de uma organização. Os conceitos do ciclo PDCA foram originalmente desenvolvidos por Walter Shewart, um estatístico pioneiro que desenvolveu o controle estatístico nos Laboratórios da Bell nos Estados Unidos, na década de 30. A eficiência do ciclo se tornou famosa, na década de 50 quando surgiu, no contexto de Gerenciamento de Qualidade, a grande autoridade, W. Eduard Deming [Deming, 1990].

O uso do PDCA ajuda a coordenar os esforços de melhoria contínua e demonstra que programas de melhoria devem iniciar sempre com um planejamento cuidadoso, que devem resultar em açōes efetivas que, por sua vez, devem levar ao planejamento, fechando, assim, um ciclo contínuo.

O ciclo PDCA (Plan, Do, Check, Act), apresentado na Figura 4.1 é composto pelas seguinte etapas: 


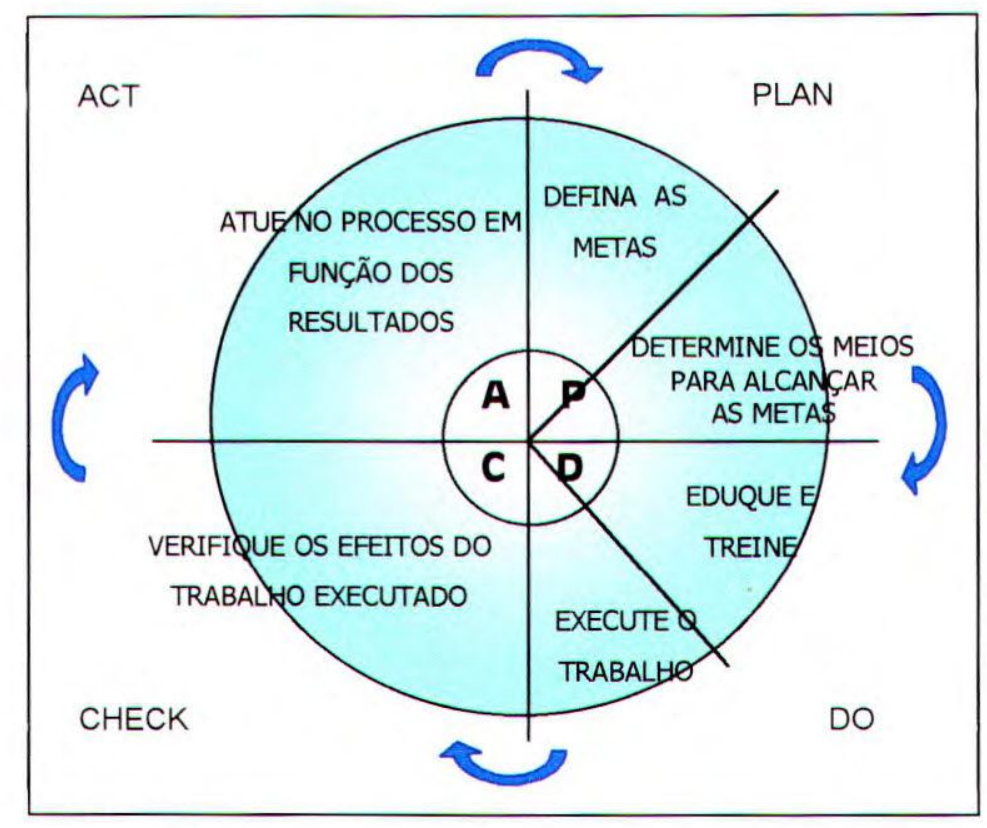

Figura 4.1:Ciclo PDCA [Werkema, 1995]

\section{Planejamento (P)}

Essa etapa estabelece as metas da organização e desenvolve métodos para alcançar essas metas. Isso significa selecionar as operações que são causadoras de problemas e desenvolver idéias para resolver esses problemas.

\section{Execução (D)}

Nessa etapa, executam-se as tarefas que foram previstas na etapa de planejamento e coletam-se dados que serão utilizados na próxima etapa de verificação do processo. É importante que as mudanças sejam implementadas em escalas menores para primeiro testar sua eficiência para que os erros não causem grandes catástrofes ao processo já em andamento. Assim, pode-se verificar se as mudanças funcionam bem ou não.

Nessa etapa de execução são abordados a educação (disseminação de novos conceitos e tecnologia) e o treinamento (aperfeiçoamento de conceitos já conhecidos). 


\section{Verificação (C)}

Nessa etapa, é realizada uma comparação entre os dados coletados na etapa de Execução e as metas definidas na etapa de Planejamento. Para isso, verifica-se se a escala menor de implementação ou mudanças experimentais alcançaram os resultados esperados.

\section{Ação (A)}

Essa etapa consiste em atuar no processo em função dos resultados obtidos. Se o sucesso é obtido em uma escala menor, pode significar que a mudança pode fazer parte das atividades da organização, envolvendo outras pessoas, outros departamentos, fornecedores e clientes afetados pelas mudanças. $O$ envolvimento dessas outras pessoas é importante para ajudar na implementação das mudanças numa escala maior, ou mesmo para a conscientização dos novos benefícios que podem adquirir com as mudanças.

Existem duas formas de atuação possiveis: adotar o plano como padrão, caso a meta tenha sido alcançada; ou agir sobre as causas que não permitiram que as metas sejam efetivas.

Para entender como funciona o ciclo PDCA é importante saber que existem dois tipos de metas a serem atingidas por uma organização:

1. Metas para Manter: também conhecidas como metas padrão, representam uma faixa aceitável de valores que devem ser mantidos pelas características consideradas importantes no produto.

2. Metas para Melhorar: também conhecidas como metas de melhoria, surgem do fato de que o mercado sempre deseja um produto cada vez melhor, a um custo cada vez mais baixo e com entrega cada vez mais precisa. $O$ surgimento de novos concorrentes no mercado, novas tecnologias, novos materiais também levam a necessidade de estabelecer metas de melhoria. Atingir uma meta de melhoria implica em modificar a atual condição de trabalho.

Algumas ferramentas de qualidade podem ser integradas ao ciclo PDCA exercendo o papel de instrumentos de coleta, armazenamento e processamento das informaçōes necessárias à manutenção e melhoria dos resultados do processo de uma organização. Como exemplo dessas ferramentas de qualidade podemos citar, diagrama de causa e efeito, histogramas, diagrama de dispersão, entre outros. 


\subsubsection{O Modelo IDEAL}

O modelo IDEAL versão 1.1 (Figura 4.2) descreve uma abordagem sistemática de gerência que ajuda as organizações a melhorar o seu processo de software. A melhoria é obtida através da introdução de novas políticas, tecnologias, métodos e ferramentas para a construção de um ambiente de desenvolvimento mais eficiente.

O Modelo IDEAL foi desenvolvido pela SEl (Software Engineering Institute) e estabelece um programa de melhoria continua de processo de software. Tem como focos principais o gerenciamento do programa de melhoria e estabelecimento de condiçőes para uma estratégia de melhoria em longo prazo.

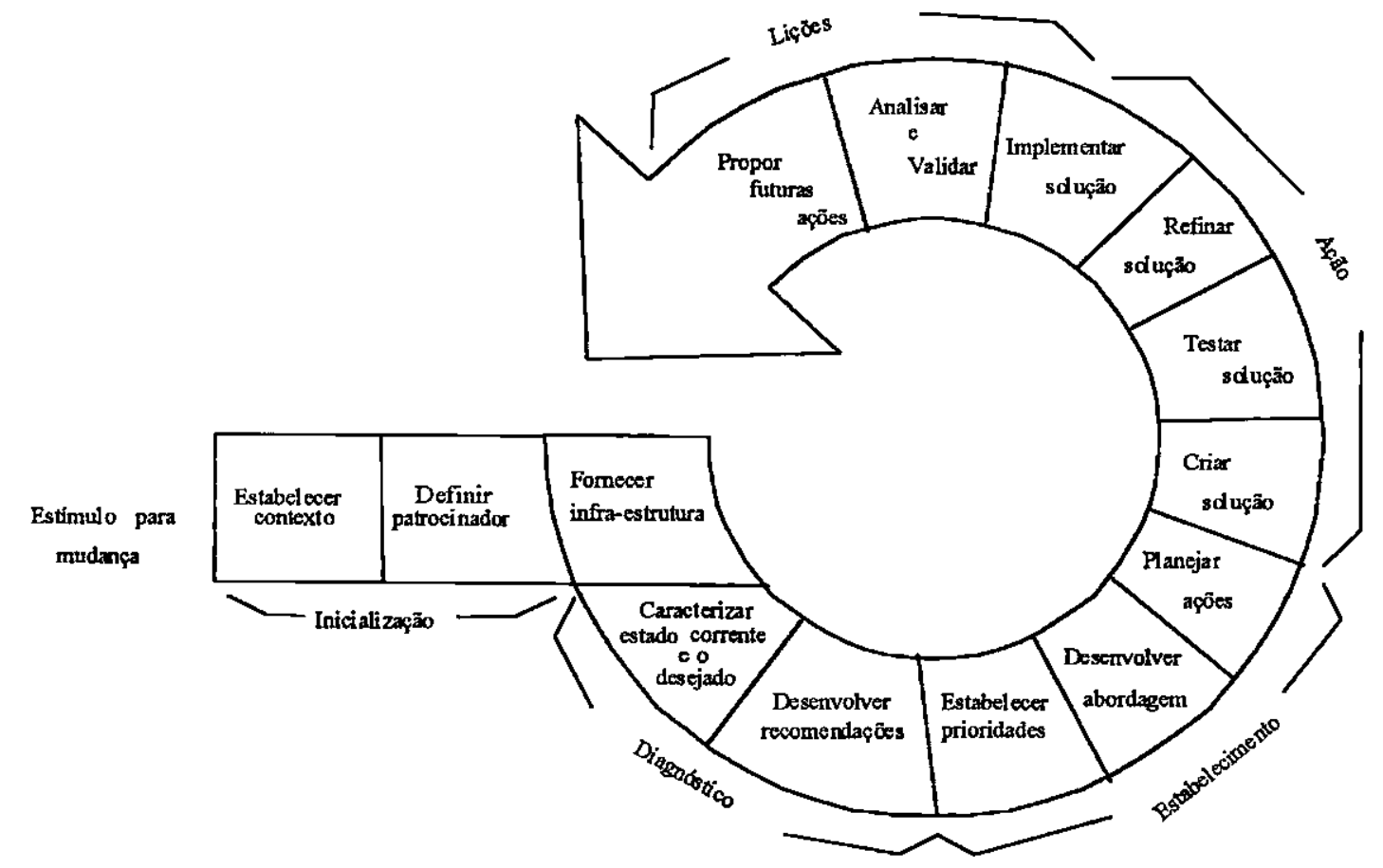

Figura 4.1: O Modelo IDEAL [Gremba, 1997]

Cada uma das fases é realizada através da execuçäo de uma séne de atividades descrias a seguir.

\section{A Fase de Inicializaçăo}

Nessa fase, deve-se articular, claramente, a aplicaçäo dos esforços para satisfazer as necessidades de negócio, deve-se assegurar o suporte ao gerenciamento e deve-se, 
finalmente, colocar em prática uma infra-estrutura para gerenciar os detalhes de implementação do processo de melhoria.

O modelo é composto por 5 fases como mostra o Quadro 4.1.

\begin{tabular}{|c|c|}
\hline Initiating (Inicializaçäo) & $\begin{array}{l}\text { fornecer uma base sólida na organização para o } \\
\text { sucesso no processo de melhoria }\end{array}$ \\
\hline Dlagnosing (Diagnóstico) & $\begin{array}{l}\text { deteminar a situação atual e a situação em que se } \\
\text { espera encontrar a organização após o processo } \\
\text { de melhoria }\end{array}$ \\
\hline Establishing (Estabelecimento) & $\begin{array}{l}\text { planejar, especificamente, como chegar a situaçāo } \\
\text { esperada }\end{array}$ \\
\hline Acting (Açäo) & realizar o trabalho de acordo com o planejado \\
\hline Learning (Lições) & $\begin{array}{l}\text { aprender com a experiência e melhorar a } \\
\text { habilidade de adotar novas tecnologias no futuro }\end{array}$ \\
\hline
\end{tabular}

Quadro 4.1: As cinco fases do Modelo IDEAL [Gremba, 1997]

Essa fase é concluída com a realização das atividades a seguir:

Estímulo para Mudança: é importante definir as necessidades de negócio que alavancam as mudanças nas práticas da organização. Os estímulos para mudanças podem ser: um evento inesperado ou uma circunstância, uma ordem de alguém superior ou informações obtidas por uma atividade de "benchmarking". Em geral, quando as necessidades de mudanças são evidenciadas por razōes de negócio é mais fácil convencer a organização, como um todo, e existem maiores chances de sucesso.

Estabelecer Contexto: após estarem definidas, claramente, as razões para a meihoria, a gerência da organização pode estabelecer o contexto para o trabalho que vai ser realizado. Isso significa definir, claramente, aonde os esforços vão se enquadrar na estratégia de negócio da organização, que metas e objetivos de negócio serão afetados pelas mudanças, como isso vai incidir sobre outras iniciativas $\theta$ trabalhos futuros, e que benefícios são esperados. contexto e as implicações se tornarão mais evidentes à medida que o processo de melhoria seja encaminhado, mas é importante que essas questōes estejam definidas, de maneira mais clara possível, antes de iniciar os esforços.

Definir Patrocinador. um patrocinador efetivo é um dos fatores mais importantes para os esforços de melhoria de processo. O patrocinador deve ajudar a manter o compromisso nos momentos de dificuldades e principalmente na situação de caos que a organização pode se 
encontrar no princípio do processo de melhoria. Outra função do patrocinador é garantir os recursos essenciais utilizados durante a melhoria.

As atividades da fase de Inicialização são críticas. Se essa fase for concluída de maneira incompleta, sem muita preocupação, podem ser desperdiçados muito tempo, esforços e recursos nas fases subseqüentes.

\section{A Fase de Diagnóstico}

Nessa fase, deve-se desenvolver um entendimento maior do trabalho para a melhoria. Assim, caracteriza-se dois estados da organização: um que representa o estado atual e outro que representa o estado futuro desejado. Esses estados são usados para desenvolver a abordagem para as práticas de melhoria de negócio.

Essa fase é concluída com a realização das atividades a seguir:

Fornecer Infra-Estrutura: após definir as razões para mudança, o contexto e o comprometimento dos patrocinadores, é importante definir o mecanismo para gerenciar os esforços para os detalhes de implementação: a infra-estrutura. Ela pode ser permanente ou temporária, pode ser de tamanhos e complexidades variados. Fornecer infra-estrutura, envolve desenvolver um contrato que documente e esclareça as expectativas e descreva as responsabilidades.

Caracterizar o Estado Corrente e o Estado Desejado: caracterizar o estado corrente e o desejado é como identificar o início $\theta$ o fim da jornada. Uma vez identificado o estado atual, pode-se usar o CMM para definir o estado desejado.

Desenvolver Recomendações: nessa atividade, desenvolve-se recomendaçōes, sugerindo meios de como proceder em atividades subseqüentes. As atividades da fase de Diagnóstico são desempenhadas pelas pessoas mais experientes ou por especialistas relevantes na organização. Suas recomendações são baseadas nas decisões realizadas pelos gerentes chefes e patrocinadores.

\section{A Fase de Estabelecimento}

A proposta dessa fase é desenvolver um plano detalhado do trabalho. São definidas as prioridades que refletem as recomendaçōes realizadas na fase de Diagnóstico e as restrições 
do ambiente de operaçōes. Desenvolve-se depois, uma abordagem que honra esses fatores de prioridades e finalmente, ações específicas, prazos, produtos liberáveis e responsabilidades são incorporadas ao plano de ação.

Essa fase é concluída com a realização das atividades a seguir:

Estabelecer Prioridades: a primeira atividade dessa fase é definir as prioridades para os esforços de mudança. Essa prioridade deve considerar vários fatores: limitação de recursos, dependências entre as atividades recomendadas, intervençāo de fatores externos e as prioridades globais da organizaçāo também devem ser honradas.

Desenvolver Abordagem: essa atividade combina a crescente compreensão do escopo do trabalho com o conjunto de prioridades, levando a desenvolver uma estratégia de acompanhamento do trabalho e identificação da disponibilidade dos recursos. Para isso, devem ser considerados: os fatores técnicos que podem incluir, instalação de novas tecnologia e necessidade de novas habilidades e conhecimento para usar essa tecnologia; e os fatores não-técnicos que podem incluir a cultura organizacional, nlveis de patrocinadores e forças de vendas.

Planejar as Ações: com a abordagem definida, pode-se desenvolver um plano detalhado de implementaçăo. Esse plano inclui cronograma, tarefas, prazos, pontos de decisāo, recursos, responsabilidades, medidas, mecanismo de acompanhamento, riscos e mitos, estratégias, e muitos outros elementos requeridos pela organização para o processo de melhoria contínua.

\section{A Fase de Ação}

As atividades dessa fase ajudam a organização a implementar o trabalho que foi contextualizado e planejado nas três fases anteriores. Essas atividades, tipicamente, consomem mais tempo e recursos que todas as outras fases combinadas.

Essa fase é concluída com a realização das atividades a seguir:

Criar Soluçōes: a fase de Ação começa associando todos os elementos chaves para criar a melhor soluçăo imaginável destinada às necessidades previamente identificadas da organização. Esses elementos chaves incluem ferramentas existentes, processos, conhecimentos e habilidades, além de novos conhecimentos, informaçōes e ajudas externas. A 
solução, que pode ser complexa e possuir muitas faces, geraimente é criada por um grupo técnico de trabalho.

Testar a Solução: uma vez criada a solução, ela deve ser testada, pois por mais que a solução seja bem elaborada ela raramente funciona como o planejado. Isso geralmente é acompanhado por um teste piloto, mas podem ser usados outros meios.

Refinar a Solução: após a solução ter sido testada, ela pode ser modificada para refletir o conhecimento, a experiência e as liçōes que foram obtidos pelos testes. Podem ser necessárias várias iteraçōes do processo de refinamento e testes para alcançar uma solução satisfatória.

Implementar Soluções: nessa etapa, pode-se implementar a solução por toda a organização, uma vez que ela já esteja preparada. Várias abordagens podem ser utilizadas para essa implementação como top-down (começando pela parte superior da organização) ou just-in-time (implementando projeto por projeto em seu tempo apropriado). Não existe uma abordagem que seja incomparavelmente melhor que outras, ela deve ser escolhida de acordo com a natureza da melhoria e as circunstâncias da organização. Para grandes mudanças, implementar essas soluções pode requerer tempo e recursos consideráveis.

\section{A Fase de Lições}

A fase de Lições complementa o ciclo de melhoria. Uma das metas do Modelo IDEAL é melhorar continuamente a capacidade de implementar mudanças. Na fase de Lições, toda a experiência adquirida é revista para determinar o que foi cumprido, onde os esforços cumpriram as metas desejadas, e como a organização pode implementar melhorias mais eficientemente no futuro. As informações de todo o ciclo do IDEAL devem ser armazenadas para serem utilizadas nessa fase.

Essa fase é concluída com a realização das atividades a seguir:

Analisar e Validar: essa atividade responde a uma série de perguntas. De que maneira o esforço cumpriu a proposta esperada? O que funcionou melhor? $O$ que pode ser feito para melhorar a eficiência? As Lições são coletadas, analisadas, resumidas e documentadas. As necessidades de negócio identificadas durante a fase de Inicialização são re-examindas para verificar se elas foram satisfeitas. 
Propor Futuras Ações: durante essa atividade, as recomendações baseadas na análise e na validação são desenvolvidas e documentadas. Propostas de melhoria para implementação de futuras mudanças são também fornecidas.

\subsection{Contexto de Avaliação do Processo de Software}

A avaliaçāo de processo significa capturar informaçōes que descrevam a capacidade real do processo de uma organização e é motivada pelo desejo de determinar ou melhorar a capacidade desse processo [SPICE4,1997]. Um requisito de uma avaliação pode ser a necessidade comercial refletida em: redução de custo, melhoria de qualidade e diminuição do tempo de produção. A suposição fundamental é que esses fatores são largamente determinados pelo processo de desenvolvimento [Dunaway, 1996].

Existem muitas variáveis que podem influenciar o sucesso de uma avaliação, principalmențe por que o processo de software que se avalia é um processo complexo com vários elementos (pessoas, responsabilidades, ferramentas, etc.). Além disso, para a avaliação ter sucesso é preciso que exista: comprometimento, motivação, confidencialidade, relevância e credibilidade [SPICE4, 1997].

Sendo assim, para realizar uma avaliação de maneira organizada e controlada é importante que essa avaliação seja planejada, com antecedência, considerando-se todos os elementos que fazem parte do processo de avaliação de software.

Deve-se utilizar um plano de avaliação de software que contenha os objetivos, as atividades, o cronograma, as pessoas envolvidas, o comprometimento, enfim, tudo que possa dizer respeito ao processo de avaliação.

O plano de avaliação proposto neste trabalho e apresentado no capítulo a seguir, é baseado em diretrizes propostas pela SEI para auxiliar na criação de um plano de avaliação baseado no modelo CMM, essas diretrizes estão contidas num documento denominado CAF (CMM Appraisal Framework) [Masters, 1995]. 


\subsection{O Modelo CAF (CMM Appraisal Framework)}

O Modelo CAF foi elaborado para orientar a criação de uma estratégia de avaliação baseada no modelo CMM e para fornecer uma base que permita comparar os resultados de uma avaliação com outras.

O CAF é um documento que identifica os requisitos e as características desejáveis de uma avaliação, e ainda, melhora a consistência e a confiabilidade dos métodos de avaliação e dos seus resultados. Ele fornece um modelo para medir a maturidade do processo de uma organização em relação a um modelo de referência através de um método de avaliação.

O CAF inclui uma arquitetura e uma descrição dos requisitos para um método de avaliação genérico. Na Figura 4.3, pode-se observar que a avaliação CAF é realizada através do cumprimento de três fases: Planejamento e Preparação da Avaliação, Condução da Avaliação e Reporte dos Resultados.

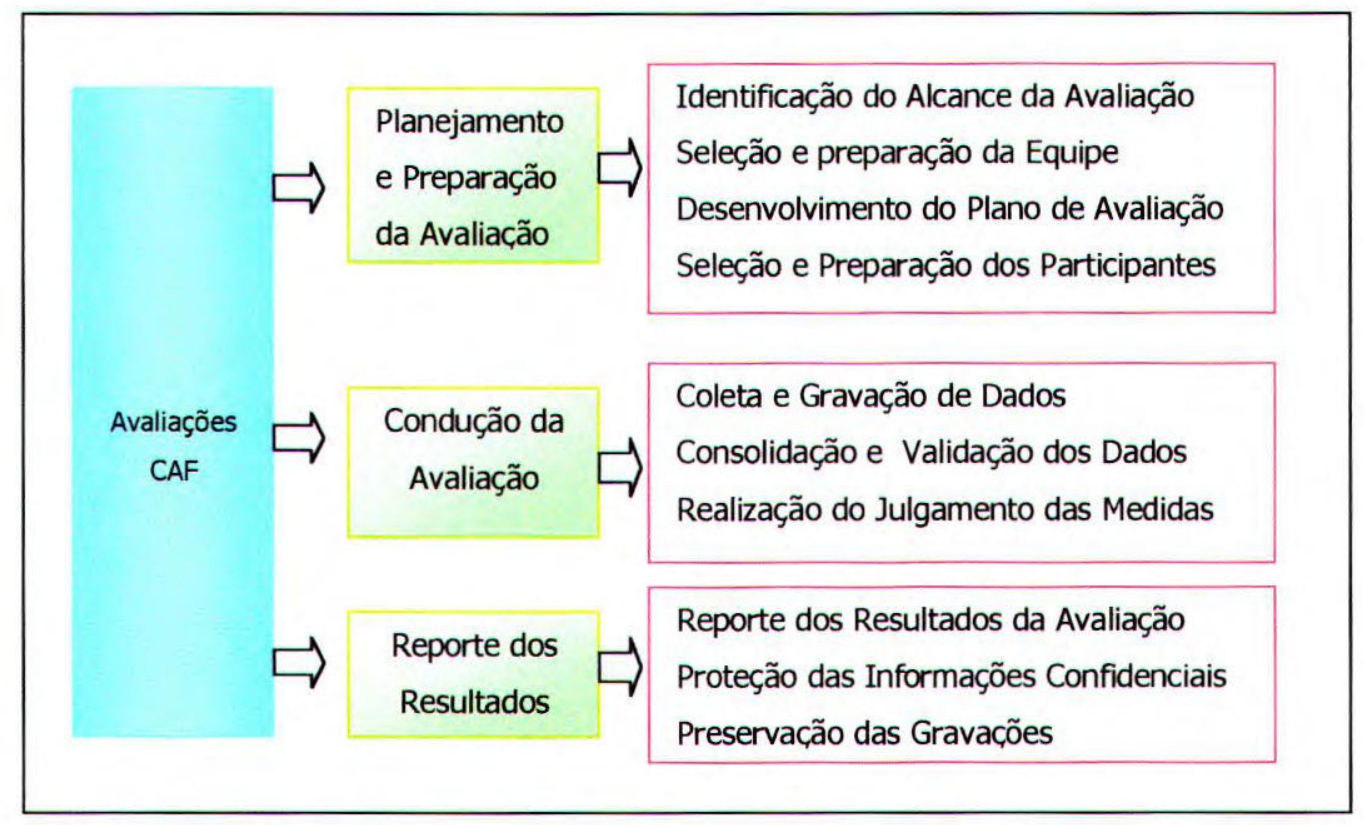

Figura 4.1: Arquitetura do CAF com algumas modificações [Masters, 1995]

Cada fase é composta por algumas atividades que são descritas mais detalhadamente a seguir. 


\section{Preparação e Planejamento da Avaliação}

Planejar e preparar a avaliação é a chave do sucesso para qualquer avaliação [Masters, 1995]. Isso envolve analisar os requisitos da avaliação, selecionar e preparar a equipe de avaliadores $\theta$ os participantes da avaliação e desenvolver $\theta$ documentar um plano de avaliação.

Essa fase é concluída com a realização das seguintes atividades:

\section{Identificar o Alcance da Avaliação}

Nessa atividade, deve-se identificar e avaliar os objetivos e as restrições da avaliação. Os objetivos variam de organização à organização dependendo das necessidade de negócio, como exemplo, para selecionar um fornecedor de software ou mesmo para realizar uma melhoria interna.

Ainda nessa atividade, deve-se estabelecer o escopo da avaliação. Esse escopo inclui a definição da parte do CMM que será usada como referência. Pode ser algum nível de maturidade específico, ou mesmo a escolha de algumas áreas-chave. Deve-se também, definir - alcance da avaliação dentro da organização. Isso significa delimitar as unidades da organização onde sé aplicarão os resultados da avaliação, pode ser toda a organização, ou uma unidade específica ou mesmo uma simples equipe de desenvolvimento.

Também faz parte dessa atividade definir as responsabilidades da avaliaçāo.

comprometimento, por parte da organização avaliada, é essencial para manter um respaldo à equipe de avaliação, para que sejam produzidos melhores resultados. É importante que haja comprometimento, também, por parte do patrocinador (que se compromete a financiar a avaliação) e por parte do gerente sênior que desempenha um papel importante no bom andamento da avaliação.

\section{Seleção e Preparação da Equlpe de Avaliadores}

Nessa atividade, deve-se definir a qualificação mínima requerida pelos avaliadores que compõe a equipe de avaliação. A equipe deve ser capaz de combinar conhecimento, habilidades e experiências individuais apropriados para garantir o andamento da avaliação. 
Cada avaliador deve possuir conhecimentos de questões gerenciais $\theta$ de questões técnicas para poder realizar julgamentos posteriores.

Ainda nessa atividade, deve ser definido o tamanho da equipe que vai realizar a avaliação. A equipe não deve ser pequena, a ponto de sobrecarregar cada avaliador, mas por outro lado, numa equipe reduzida, pode ser mais fácil alcançar um consenso de maneira rápida e eficiente. Dependendo do tamanho da equipe, deve-se um ter líder que tenha experiências em aplicar o método de avaliação, tenha experiencias em gerenciar equipes, facilidade em comunicar-se, além de todas as habilidades requeridas por um avaliador.

É função do líder da equipe: zelar pela união da equipe; conhecer as habilidades, capacidade, responsabilidades dos membros da equipe, realizar orientações específicas sobre a organização avaliada como a política interna, domínio de aplicação e garantir que toda a equipe tenha conhecimento do plano de avaliação para que a avaliação possa ser cumprida efetivamente.

Além de definir as pessoas e o tamanho da equipe, pode ser necessário realizar uma preparação da equipe. A equipe deve possuir conhecimentos da estrutura do CMM, das áreaschave envolvidas, do relacionamento entre essas áreas-chave, $\theta$ a estrutura da organização.

\section{Desenvolvimento do Plano de Avaliação}

O plano de avaliação é um documento que apresenta de maneira organizada as tarefas, os comprometimentos $\mathrm{e}$ as políticas envolvidos na avaliação. Ele contém as atividades possiveis de se cumprir, dentro de esforço, custo e cronograma estimados com base na situação real da avaliação. Além disso, informaçōes como o escopo da avaliação, os objetivos e as responsabilidades também, devem fazer parte do plano.

As informações sobre os riscos envolvidos na avaliação, também devem ser identificadas e apresentadas no plano. Como exemplo de riscos tem-se: mudanças na organização, mudança no comprometimento, mudanças na equipe de avaliadores, além de outras situações que podem ser derivadas de problemas nos custos, cronograma e recursos.

Também faz parte dessa atividade, identificar as técnicas que serão utilizadas para coletar as informações, como um questionário, checklist, entrevistas com gerentes, líderes de projetos e especialistas em software, revisões de documentos, apresentações, entre outros. É importante definir como será conduzida a conscientizaçāo inicial dos participantes, se palestras ou curso serāo realizados, seu local, duraçāo e recursos requeridos para tal. 
Esse plano deve ser apresentado ao gerente sênior e para os patrocinadores e as devidas modificações devem ser propostas por cada parte. O plano deve ser aprovado em comum acordo com as principais partes de avaliação: patrocinadores, avaliadores e gerente sênior.

\section{Seleção e Preparação dos Participantes}

Os participantes devem ser selecionados de maneira a apresentarem certa representatividade dentro do escopo da avaliação, que é definido na atividade Identificar o Alcance da Avaliação.

A seleção dos participantes envolve definir uma porcentagem de pessoas envolvidas no escopo, pois muitas vezes, não é possivel que todos os membros da equipe participem da avaliação. Quanto maior a porcentagem, maior a chance de ser, de fato, representativo. Existem características na equipe que devem ser relevadas no momento da escolha dos participantes, por exemplo, se existe uma parcela pequena de profissionais experientes no projeto avaliado, entre os participantes da avaliação também deve estar presente uma parcela proporcional de profissionais experientes.

Num projeto podem existir grupos de apoio como: grupo que fornece treinamento, grupo de manutenção e suporte ou mesmo, grupo de engenharia de software. Os membros desses grupos também podem ser parte dos participantes da avaliação.

Ainda nessa atividade, é importante que os participantes recebam certas orientações, pois participantes que estejam conscientes do objetivo da avaliaçāo, das atividades planejadas e da aplicação dos resultados podem contribuir mais efetivamente no processo de avaliação. Essa orientação pode ser realizada por palestras ministradas para esse fim, ou mesmo através de reuniōes que permitam discutir e sanar as possiveis dúvidas que possam surgir por partes dos participantes. 


\section{Condução da Avaliação}

Conduzir uma avaliação representa coletar, armazenar e consolidar os dados para poder medir o processo em relaçăo ao CMM.

As seguintes atividades são realizadas para o cumprimento dessa fase:

\section{Coleta e Gravação dos Dados}

Os dados podem ser coletados através de instrumentos de avaliaçăo, apresentaçōes, entrevistas e documentos. Cada uma dessas técnicas possui suas vantagens e desvantagens, dependendo do processo de avaliação. Nada impede que essas técnicas sejam utilizadas em conjunto, como exemplo, pode-se aplicar o questionário durante uma entrevista.

\section{Consolidação e Validação dos Dados}

Consolidar os dados envolve transformar os dados coletados em informações que podem ser relacionadas ao CMM (organizando os dados relevantes e significativos dentro do escopo, buscando evidências de presença ou ausência das práticas) e determinar se elas representam algumas descobertas através de alguns procedimentos para validar as informações. Como exemplo de validação, pode-se exigir que exista mais de uma fonte da mesma informação.

Além de organizar e validar os dados deve-se determinar o critério utilizado para definir se as informaçōes sāo suficientes para cobrir:

- Uma meta: se existem evidências que as práticas estão institucionalizadas;

- Uma área-chave: se todas as suas metas forem satisfeitas;

- Um nível de maturidade: se todas as áreas-chave dos níveis anteriores forem satisfeitas.

Finalmente, deve-se implantar um mecanismo que permita guardar um histórico das origens das informaçōes. Isso é, cada informaçāo deve ter sua origem especificada, como por 
exemplo, em que documento foi encontrado tal informação ou quem se pronunciou em relação a tal informaçăo.

\section{Realização do Julgamento das Medidas}

O julgamento deve ser realizado em relaçāo aos componentes da estrutura do CMM: metas, áreas-chave $\theta$ nivel de maturidade. Existem quatro valores para julgá-los: satisfeitos, não satisfeitos não apllcável e não medido. Cada meta tem suas práticas julgadas $\theta$ será considerada satisfelta, se existirem evidências que a meta é Implementada e institucionalizada. Cada área-chave será julgada de acordo com os valores que receberam as suas metas, somente se todas as metas forem julgadas satisfeitas, a área-chave é considerada satisfeita. Cada nível de maturidade é julgado segundo o julgamento das áreas-chave dos níveis anteriores. Somente, se todas essas áreas-chave forem satisfeitas, a organização será classificada segundo o nível de maturidade.

\section{Reporte dos Resultados}

Essa fase do CAF envolve reportar os resultados aos possiveis interessados como patrocinadores e gerente sênior, além de armazenar os resultados para uma pesquisa futura. É importante que seja garantida a confidencialidade das informações armazenadas.

As seguintes atividades são realizadas para o cumprimento dessa fase:

\section{Reporte dos Resultados da Avaliação}

Essa atividade descreve como devem ser reportadas as informaçōes aos interessados. Propōe-se o conteúdo mínimo para o relatório apresentado: escopo da avaliação, os resultados, as descobertas, as pontuações, as limitaçōes e a margem de erro associado a cada informação.

\section{Proteção de Informações Confidenciais}

Tanto as respostas dos participantes da avaliação, quanto os resultados da avaliação não devem ser divulgados sem a devida permissão do patrocinador. Também é preciso garantir 
que as informações durante a coleta de dados não sejam discutidas entre os vários membros da equipe de avaliadores.

\section{Preservação das Gravações}

As informações devem ser armazenadas por alguns propósitos, como por exemplo, os planos de avaliação podem ser guardados para realizar outra avaliaçāo e mesmo os resultados, as anotaçōes, as observaçōes, as descobertas podem ser armazenados para auxiliar no aperfeiçoamento do plano de avaliação.

\subsection{Consideraçōes Finais}

Neste capítulo, o modelo de melhoria de processo PDCA e o modelo IDEAL foram abordados com mais detalhes. O primeiro, por ser o modelo mais antigo e mais conhecldo, $\Theta \circ$ segundo por ser o modelo utilizado como referência para elaboração da abordagem de avaliação deste trabalho.

O modelo de melhoria de processo escolhido para focalizar o contexto do trabalho foi o IDEAL. Para inicializar o processo de melhoria baseado no IDEAL é necessário realizar um diagnóstico do processo corrente. Para isso, as diretrizes do CAF são seguidas para auxiliar a fase de Diagnóstico.

No próximo capítulo, descreve-se como foram elaborados um plano de avaliação de processo de software e um instrumento de avaliação que auxilia na execução desse plano de avaliação. 


\section{Capítulo 5 - Elaboração do Questionário e do Plano de}

\section{Avaliação de Processo}

\subsection{Considerações Iniciais}

Neste capítulo, descreve-se como foi realizada a confecção de um questionário que é usado como o instrumento de avaliação. Posteriormente, descreve-se como foi realizada a elaboração do plano de avaliação e finalmente, apresenta-se o Plano de Avaliação de Processo proposto pelo trabalho.

O questionário e o plano fazem parte de uma estratégia de avaliação proposta para auxiliar a fase de Diagnóstico do IDEAL.

\subsection{A Abordagem de Melhoria Escolhida}

O modelo de melhoria escolhido para auxiliar na implantação de melhoria de processo de software é o modelo IDEAL, descrito no Capítulo 4.

No início do processo de melhoria é necessário avaliar o processo corrente de software, com o objetivo de caracterizar as práticas da organização. $O$ resultado dessa avaliação permite desenvolver recomendações para as atividades de melhoria subseqüentes. No modelo IDEAL, a fase de Diagnóstico cumpre essa função.

Para cumprir as atividades dessa fase é necessário elaborar um plano de avaliação de processo. A elaboração do plano apresentado seguiu as consideraçōes das atividades de Planejamento da Avaliação, Condução da Avaliação e Reporte dos Resultados da Avaliação propostas pelo CAF. Além do plano elaborou-se um instrumento de coleta de dados para auxiliar na atividade de Coleta e Validação dos Dados. Todas as tecnologias envolvidas nas elaborações, bem como os passos seguidos são apresentados na seção seguinte. 


\subsection{O Instrumento de Avaliação}

Para que a avaliação tenha sucesso, um dos fatores mais importantes, é a adequação do instrumento de coleta de dados aos objetivos da avaliaçāo. Nesse contexto, um estudo foi realizado para definir qual seria o melhor instrumento a ser utilizado.

O questionário foi escolhido como instrumento de avaliação por ser o meio mais simples de coleta de dados e por sua aplicaçāo poder ser realizada de maneira rápida e eficiente. Uma vez definido o questionário como sendo o instrumento de avaliação, era necessário decidir por elaborar uma lista de questōes, ou aplicar uma já pré-existente. Para auxiliar essa decisão o Questionário de Maturidade (QM) da SEl [ Zubrow, 1994] foi estudado.

O QM tem como função classificar uma organização segundo algum nível de maturidade verificando o cumprimento das áreas-chave do CMM. As questōes se encontram organizadas por áreas-chave e representam metas que devem ser alcançadas para que a área-chave seja considerada cumprida. Para cada área-chave é realizada de seis a sete perguntas.

Para o propósito em questão, o QM não se mostrou adequado, pois o objetivo da avaliação não é classificar a organização, e sim descobrir os pontos fracos e fortes da mesma. Os pontos fracos são utilizados para priorizar as atividades que devem ser melhoradas, $e$ os pontos fortes podem ser mantidos ou adaptados.

Para esse fim, era necessário um questionário que abordasse as áreas-chave de maneira mais detalhada e, além disso, as áreas-chave de interesse no trabaiho eram somente as do nível 2 do CMM. Portanto, optou-se por elaborar um questionário que fosse mais adequado aos objetivos da avaliação proposta.

A elaboraçāo do questionário seguiu as diretrizes propostas pela abordagem GQM (Goal-Question-Metric) [Basili, 1995], por ser essa, uma abordagem já consolidada e muito utilizada para pesquisas acadêmicas na área de engenharia de software [Rombach, 1987], [Kirner, 1997]. 


\section{A abordagem GQM Utilizada para Eiaboração do Questionário}

A abordagem GQM (Goal-Question-Metric) fornece um mecanismo para especificar os objetivos da pesquisa e orienta o refinamento desses objetivos em um conjunto de questões e métricas quantificáveis. Ela foi definida, originalmente, para avaliar defeitos em um conjunto de projetos no ambiente da NASA. Apesar da abordagem ser usada para definir e avaliar objetivos de um projeto particular em um ambiente particular, seu uso foi expandido para um contexto maior [Basili, 1995].

O resultado da aplicação do GQM é um sistema de medidas direcionado para um objetivo particular e regras para a interpretação das medidas dos dados. O modelo de medida resultante tem 3 níveis:

1 - Nível Conceitual (GOAL)

Nesse nível são colocados os Objetivos da medida. Esses objetivos focalizam o trabalho a ser realizado e definem o modelo para determinar se o objeto pesquisado tem as qualidades desejadas.

\section{Nível Operacional: (QUESTION)}

Os objetivos do estudo são traduzidos em um conjunto de Questões. As questōes permitem uma caracterização do objeto de pesquisa e dos aspectos de qualidade do mesmo.

\section{Nivel Quantitativo (METRIC)}

Nesse nível são derivadas as Métricas que descrevem quais dados devem ser coletados para responder as questões.

A abordagem pode ser definida, resumidamente, em seis passos básicos, mostrados no Quadro 5.1.

Para a elaboração do questionário, foi suficiente a consideração dos quatro primeiros passos.

PASSO 1: Estabelecer os Objetivos da Coleta de Dados

Os objetivos podem ser definidos em termos de: Objeto de Estudo, Propósito, Perspectiva e Ambiente [Basili, 1995]. 


\begin{tabular}{|l|l|}
\hline Passo 1 & Estabelecer objetivos da coleta de dados \\
\hline Passo 2 & Desenvolver uma lista de questões de Interesse \\
\hline Passo 3 & Estabelecer as métricas \\
\hline Passo 4 & Projetar e testar o instrumento de coleta de dados \\
\hline Passo 5 & Coletar e validar os dados \\
\hline Passo 6 & Analisar os dados \\
\hline
\end{tabular}

Quadro 5.1: Os seis passos do GQM [Basili, 1985]

- Objeto de Estudo: um processo ou um produto;

- Propósito: determinar, entender, melhorar, caracterizar, avaliar, prever, motivar, ou controlar algum aspecto de qualidade do objeto e pesquisa;

- Perspectiva: identificar quem está interessado nos resultados da pesquisa;

- Ambiente: fornecer o contexto para as interpretações dos resultados.

No trabalho realizado, esse passo tem o Quadro 5.2 como resultado.

\begin{tabular}{|l|l|}
\hline \multicolumn{2}{|c|}{ Objetivos } \\
\hline Objeto & Processo de Software \\
\hline Propósito & $\begin{array}{l}\text { Verificar a qualidade do processo } \\
\text { baseando-se nas áreas-chaves do nível } \\
2 \text { do CMM }\end{array}$ \\
\hline Perspectiva & Administrativo \\
\hline Ambiente & Grupo de Desenvolvimento de Software \\
\hline
\end{tabular}

Quadro 5.2: Objetivos da Avaliação segundo GQM

\section{PASSO 2: Desenvolver uma Lista de Questões de Interesse}

As questões de interesse permitem uma definição mais nitida do objetivo da pesquisa, pois essas forçam os investigadores a considerar a análise de dados antes que eles sejam coletados [Rombach, 1987].

No trabalho desenvolvido, as listas de questões são referentes às práticas que devem ser cumpridas para cada área-chave de processo do nível 2 do CMM. São as chamadas práticas-chave. Porém, como o objetivo da avaliação proposta é verificar o cumprimento ou 
não dessas práticas, não fazem parte do questionário as práticas-chave referentes a medições, validações e políticas. Todas as práticas-chaves do nível 2 do CMM estão apresentadas no apêndice 1. As práticas que foram escolhidas para compor o questionário são as classificadas como Tarefas.

\section{PASSO 3: Estabelecer as Métricas}

As métricas são definidas baseando-se nas abstrações, conceitos e propriedades associados ao objeto.

Na elaboraçāo do questionário, a métrica utilizada foi baseada nas propostas da própria SEl através do Questionário de Maturidade. As possíveis respostas são sim, não, não sei e não se aplica.

A resposta sim deve ser marcada quando a prática é bem estabelecida e desempenhada consistentemente.

A resposta não deve ser assinalada quando a prática não é bem estabelecida ou é realizada inconsistentemente.

A resposta não sei deve ser assinalada quando não se está seguro da reposta.

A reposta não se aplica deve ser assinalada quando a prática em questão não se aplica ao contexto avaliado.

Após o término dos passos 1,2 e 3 tem-se o questionário concluido. A Figura 5.1 exemplifica parte das questões para uma área-chave do questionário que é apresentado integralmente no apêndice 2.

O questionário resultante contém 65 questões relacionadas às áreas-chave do nível 2 do CMM. Dentro de cada área-chave as questōes estão divididas por metas.

PASSO 4: Projetar e Testar o Instrumento de Coleta de Dados

O instrumento de coleta deve ser projetado para fornecer os dados necessários à pesquisa. Deve ser objetivo, de fácil entendimento e com pequeno gasto de tempo para seu preenchimento. Para garantir essas características é importante que o questionário seja testado antes que ele seja utilizado, efetivamente. 


\section{Planejamento de Projeto de Software}

Meta1: As estimativas de software são documentadas para serem utilizadas no planejamento e acompanhamento do projeto de software.

9: As estimativas de tamanho de produto de trabalho são realizadas?

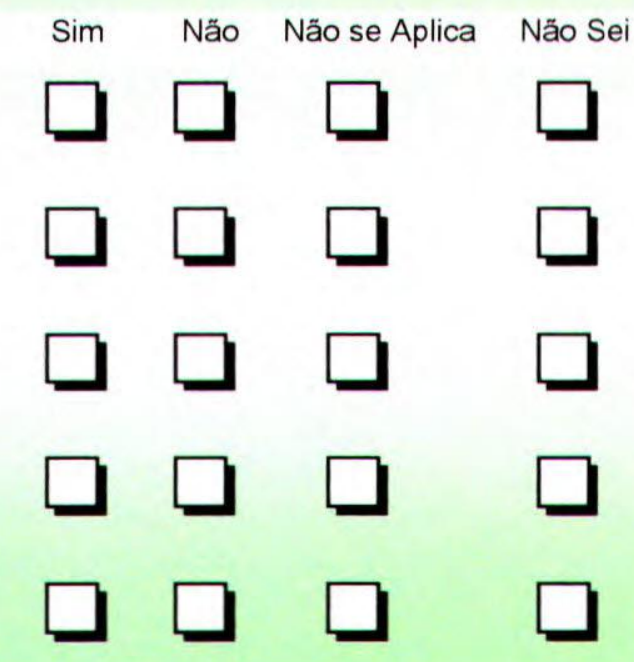

10: As estimativas de esforço e custo de projeto são realizadas?

11: As estimativas para o projeto de recursos computacionais criticos são realizadas?.......

12: O cronograma do projeto de software é estabelecido?...

15: Todas as informaçōes obtidas durante 0 planejamento de software são registrados?.

Figura 5.1: Apresentação de parte do questionário elaborado

Se a coleta de dados da avaliação é realizada através de entrevistas, pode ser de grande ajuda realizar um teste piloto, entrevistando alguém para estimar o tempo que pode levar cada entrevista. Ou mesmo, no caso em que os participantes responderão individualmente o questionário, é interessante saber com antecedência as dificuldades que o respondente pode ter.

O questionário foi testado com um membro do centro de informática de uma outra universidade antes de ser aplicado, efetivamente.

À partir desse teste-piloto pôde ser verificado que a duração requerida para o preenchimento do questionário era de aproximadamente uma hora. Verificou-se também que as questões apresentavam informações que não eram triviais, decidindo-se por isso, optar pela entrevista com o respondente para preencher as questões. Isso permitiria realizar qualquer esclarecimento no momento do preenchimento. 


\subsection{O Plano de Avaliação de Processo de Software}

O grande desafio de se realizar uma avaliação, de maneira organizada e controlada é que motiva a necessidade de se elaborar um plano de avaliação que considere todos os elementos que farão parte da avaliação de processo de software.

Esse plano deve conter os objetivos, as atividades, o cronograma, as pessoas envolvidas, o comprometimento, enfim, tudo que possa dizer respeito ao processo de avaliação.

O plano de avaliação proposto neste trabalho é baseado no modelo CAF, descrito no capítulo anterior, que auxilia na criação de um plano de avaliação baseado no modelo CMM.

\subsubsection{A Elaboração do Plano de Avaliação de Processo de Software}

As fases propostas pelo CAF auxiliaram a elaboração do plano. Essas fases representam as etapas que foram cumpridas, passo a passo, para que se produzisse, no final, um plano. Esse plano orienta a realização de uma avaliação de processo baseada no nível 2 do CMM, para pequenos grupos de desenvolvimento de software.

A seguir, apresentam-se as considerações e decisōes que foram realizadas para a elaboração dos itens do plano.

A seção 1 de Introdução do plano é dividida em cinco subseções: Objetivos, Escopo, Termos-Chave, Responsabilidades e Referências.

O objetivo da avaliação é ajudar a realizar melhoria interna. O escopo do CMM escolhido é o nível 2 do CMM, uma vez que, quase todas as empresas pequenas do Brasil ainda se encontram no nível 1, e o escopo da empresa escolhido é um projeto que tenha seu próprio cronograma e orçamento.

Deve-se, também, atribuir as responsabilidades de patrocinador e gerente sênior, avaliador e participantes para que sejam definidos os comprometimentos por cada parte. 
A qualificação mínima exigida para ser um avaliador é que se conheça a estrutura do CMM, como ele é utilizado, os seus níveis de maturidade, principalmente o nível 2 , e que possua bom conhecimento de engenharia de software. O tamanho da equipe é estabelecido como dois, ou seja, dois avaliadores são suficientes.

Quanto aos participantes da avaliação, são todos aqueles que estão envolvidos com o projeto escolhido. Assim, não existe nenhum perigo de má representatividade dos participantes. A preparação desses participantes deve ser realizada ministrando-se apresentações sobre o CMM e sobre o contexto de melhoria de processo. Reuniões que permitam discussões sobre esses assuntos também são de grande ajuda.

No plano proposto ainda foram incluídos os termos-chave usados no plano. Conceitos de engenharia de software e utilizados pelo CMM e IDEAL são apresentados. Foi incluída também uma Bibliografia para ser consultada caso seja necessário maiores esclarecimentos sobre os temas abordados pelo plano.

Na seção 2 do plano são apresentadas as três atividades que devem ser realizadas na fase de Condução da Avaliação: Coleta e Gravação dos Dados, Consolidaçāo e Validação dos Dados e Realização do Julgamento das Medidas.

Os dados devem ser coletados através do questionário proposto no início deste capítulo. O preenchimento do questionário deve ser realizado em forma de entrevistas, pois o avaliador deve estar presente para tirar qualquer dúvida nas questōes.

Os dados coletados devem ser agrupados por área-chave, o que é realizado automaticamente pela disposição das questōes no questionário. Cada conjunto de respostas deve ser analisado para verificar o cumprimento ou não da área-chave do nível 2.

À partir das informaçōes da atividade anterior é possível julgar cada área-chave segundo os valores: satisfeito, não satisfeito, não aplicável e não medido. No questionário proposto todas as perguntas de cada área-chave devem ser respondidas sim para que a áreachave seja considerada satisfeita.

Na seção 3 do plano são apresentadas as atividades de Reporte de Resultados que descreve a maneira como os resultados devem ser reportados e suas análises. Ainda nessa seção, as atividades de Proteção das Informações Confidenciais e a de Preservação das Gravações devem ser explicitadas. 
Os resultados devem ser apresentados aos possiveis interessados em forma de relatórios que contenham resultados, representados graficamente, para ajudar na visualização. Uma reunião para discutir as conclusões também pode ser encorajada.

Os questionários respondidos devem ficar de posse dos avaliadores e não se deve discutir as respostas com as pessoas envolvidas na avaliação.

Qualquer tipo de anotação, observação e documentos em relação ao plano devem ser guardados para aperfeiçoar a estratégia de avaliação. Também, os resultados e análise devem ser gravados para manter um histórico das avaliações.

Na seção 4 do plano são apresentadas, com base na situação real do processo de avaliação, as estimativas de recursos necessários e o cronograma das atividades.

Levando-se em conta essas considerações, a estrutura do plano elaborado é apresentada na Figura 5.2 e o plano completo é apresentado na seção que segue.

\section{Plano de Avaliação do Processo de Software}

1. Introdução

1.1. Objetivo

1.2. Escopo

1.3. Papéis e Responsabilidades

- Patrocinador

- Gerente Sênior

- Participantes da Avaliação

- Avaliadores

1.4. Termos-Chaves

1.5. Referências

2. Atividades de Avaliação

2.1. Coleta e Gravação dos Dados

2.2. Consolidação e Validação dos Dados

2.3. Realização do Julgamento das Medidas

3. Reporte dos Resultados

3.1. Reporte dos Resultados da Avaliação

3.2. Proteção de Informações Confidenciais

3.3. Preservação das Gravações

4. Estimativas de Cronograma e Recursos

4.1. Cronograma

4.2. Recursos

Figura 5.1: Estrutura do Plano de Avaliação Elaborado 


\subsubsection{O Plano de Avaliação de Processo}

\section{O plano de avaliação resultante é apresentado a seguir.}

\section{Introdução do Plano}

\subsection{Objetivo}

O objetivo deste plano é orientar a realização de avaliação de processo de software visando melhoria interna. Este plano contém informações que auxiliam a organizar, conduzir e acompanhar as tarefas necessárias para que uma avaliação de processo de software seja realizada.

O plano proposto auxilia a identificação de pontos fortes e fracos de uma organização em relação a um modelo de referência: Nível 2 do CMM.

\subsection{Escopo}

O plano é proposto para ser utilizado por pequenas empresas ou por organizações grandes que possuam seus próprios centros de desenvolvimento de sistemas, para utilização interna.

$\mathrm{Na}$ identificação do Escopo é necessário definir um projeto dentro da organização que deve ser avaliado. Esse projeto é uma instância do processo de software que tenha seu próprio orçamento e cronograma.

\subsection{Papéis e Responsabilidades}

Apresenta-se nessa subseção as responsabilidades atribuídas para cada parte envolvida na avaliação:

- Patrocinador: é responsável pelo respaldo financeiro da avaliação. Muitas vezes esse papel é desempenhado pelo próprio responsável pela organização como o seu dono ou o diretor de uma empresa;

- Gerente sênior: é responsável pela garantia do andamento da avaliação, fornecendo todos os recursos, a disponibilidade da equipe avaliada e outros tipos de suportes que não sejam a parte financeira. Muitas vezes o patrocinador e o gerente sênior se confundem numa mesma pessoa. Isso não impede que a avaliação tenha sucesso.

- Participantes da Avaliação: são aqueles envolvidos com o projeto que participarão do processo de avaliação, respondendo aos questionários e fornecendo qualquer outro tipo de informação. Devem ser escolhidos de maneira a serem representativos dentro do projeto. A preparação desses participantes deve ser realizada ministrando-se palestras sobre o CMM e sobre o contexto de melhoria de processo;

- Avaliadores: são os responsáveis pela avaliação. Geralmente é necessário montar uma equipe de avaliadores com um líder. Esse avaliador pode ser uma pessoa, devidamente treinada da própria organização. O avaliador deve ter conhecimento prévio de conceitos de engenharia de software, do modelo CMM e o modelo IDEAL.

\subsection{Termos-Chave}

áreas-chave: práticas do modelo CMM que evidenciam cumprimento de atividades de engenharia de software

CMM: Capability Maturity Model, modelo de maturidade de processo de software

garantia de qualidade: atividade de engenharia de software que oferece gerenciamento do processo que está sendo usado e do produto que está sendo construído

gerenciamento de configuração: atividade de engenharia de software que tem como função manter a integridade dos produtos de software 
GQM: Goal-Question-Metric abordagem que auxilia a condução de uma pesquisa

IDEAL: Initiating, Diagnosing, Acting, Establishing, Learning, abordagem de melhoria de processo de software proposta pela SEI

nível de maturidade: cada uma das categorias que o CMM classifica as organizações

metas: os objetivos que devem ser cumpridos para implementação de cada área-chave

práticas-chaves: tarefas que devem ser cumpridas em cada área-chave. Elas podem ser classificadas como: compromisso para realizar, condiçōes para desempenhar, tarefas, medições e análise verificação

processo de software: envolve políticas, responsabilidades, custos, cronogramas, enfim todas as variáveis que influenciam o desenvolvimento de um software

SEI: Software Engineering Institute, órgão governamental dos EUA com a sede na Universidade de Carnegie-Mellon

\subsection{Referências}

Engenharia de Software

- PRESSMAN, R. S., Engenharia de Software, 3ed, Rio de Janeiro, Makron Books, 1995;

Qualidade de Software

- KAN, S. H., Metrics and Models in Software Quality Engineering, Addison-Wesley, EUA, 1995;

- PAULK, M. C.; CURTIS, B.; CHRISSIS, M. B., Capability Maturity Model for Software, versão 1.1, CMU/SEI-93-TR-24, fevereiro, 1993;

- GREMBA, J.jMYERS, C., The IDEAL Process Model: A Practical Guide for Improvement, http://www.sei.cmu.edu/activities/Ideal/ideal.bridge.html, [acessado em 25/08/98];

- MASTERS S.; BOTHWELL C., CMM Appraisal Framework versão1.0, Relatório Técnico TR-95001, Software Engineering Institute, 1995.

Elaboraçāo de Planos

- ANSIIEEE Standard for Software Project Management Plans, IEEE Software Engineering Standards Collection, primavera, 1991;

- PACHECO, R. F.; SANCHES R., Gerenciamento de Configuraçäo de Software, Relatório Técnico ICMSC, n. 57, junho, 1997.

\section{Atividades de Avaliação}

\subsection{Coleta e Validação dos Dados}

É proposta a utilização do questionário elaborado (com base no nível 2 do CMM e nas métricas propostas pelo Questionário de Maturidade da SEI), que tem como função capturar as informaçōes necessárias para os objetivos da avaliação e pertinentes ao escopo escolhido na seção 1.1 e seção 1.2 deste plano, respectivamente.

Propõe-se que a aplicação do questionário seja realizada através de entrevistas individuais com os participantes da avaliação definidos na seção 1.3 deste plano. $O$ tempo de duração de cada entrevista não deve exceder uma hora. As informações que necessitam ser comprovadas através de documentos devem ser conferidas pessoalmente pelo avaliador.

\subsection{Consolidação e Validação dos Dados}

A validação consiste em verificar se as repostas dos questionários não apresentam dados inconsistentes, se não existem questōes que não foram respondidas, ou que tenham mais de uma resposta e verificar possíveis ocorrências de erros. 
Os dados coletados devem ser agrupados por área-chave, isso é realizado automaticamente pela disposição das questões no questionário. Cada conjunto de respostas deve ser analisado para verificar o cumprimento ou não de cada área-chave do nível 2.

\subsection{Realização do Julgamento das Medidas}

A partir das informações da atividade anterior é possivel julgar cada área-chave segundo os valores: satisfeito, não satisfeito, não aplicável e não medido. No questionário proposto, todas as perguntas de cada área-chave devem ser respondidas sim para que a área-chave seja considerada satisfeita.

\section{Reporte dos Resultados}

\subsection{Reporte dos Resultados da Avaliação}

Nesta seção deve ser explicitada a maneira como os resultados serão reportados. Um relatório com informações como o escopo, objetivos, data, local e informações sobre os resultados da avaliação, bem como análise dos resultados deve ser apresentada.

Os resultados podem ser apresentados graficamente através de diagramas de barras, de pizza, gráficos ou mesmo dispostos em tabelas para facilitar a sua visualização. Além do relatório, os resultados podem também ser relatados em forma de uma apresentação expondo todas as informações que sejam de interesse dos patrocinadores e gerente sênior.

\subsection{Proteção de Informações Confidenciais}

A confidencialidade das informações deve ser garantida. É importante que sejam definidos o que pode e como podem ser divulgadas essas informações através de publicações e outros meios. Além disso, a confidencialidade das informações entre os membros da própria organização deve ser estabelecida, para garantir a individualidade de cada participante.

\subsection{Preservação das Gravações}

É importante realizar um histórico das anotações, observações, qualquer informação que possa ser útil: para os avaliadores para aperfeiçoar o processo de avaliação, e para os avaliados e patrocinadores para poder realizar pesquisas posteriores.

\section{Estimativas de Cronograma e Recursos}

\subsection{Cronograma}

O cronograma deve conter o tempo requerido para cada atividade da avaliação, separadamente. Como exemplo, o período para coleta de dados e tempo requerido para realizar a análise das informações.

$\mathrm{O}$ cronograma pode ser apresentado em forma de diagrama de tarefas que permite visualizar paralelismo entre as atividades, se houver.

\subsection{Recursos}

Descreve os recursos que devem estar disponíveis para realizar a avaliação. Como exemplo, podemos citar, sala de reuniões, recursos áudio-visuais para palestras, salas para realizar entrevistas individuais e outros. 


\subsection{Considerações Finais}

Neste capítulo foram apresentados os passos para a elaboraçāo de um plano de avaliação para cumprir a fase de Diagnóstico do modelo IDEAL. Além do plano, um questionário foi proposto para ser utilizado na avaliação para permitir que a avaliação possa ser realizada de maneira simples e rápida.

No capítulo seguinte é apresentado um estudo de caso que permitiu aplicar o questionário e o plano proposto numa avaliação real. 


\section{Capítulo 6 - Avaliação de Processo: Um estudo de Caso}

\subsection{Considerações Iniciais}

Neste capítulo, apresenta-se a execução real do plano de avaliação elaborado. Nessa execução o questionário foi aplicado como parte das atividades planejadas.

A avaliação do estudo de caso seguiu a estratégia proposta pelo CAF.

\subsection{O Ambiente de Desenvolvimento de Software do Estudo de Caso}

O estudo de caso foi realizado num ambiente de desenvolvimento de software de uma universidade privada. A universidade possui muitos procedimentos internos controlados por sistemas de computador distribuídos por todo o campus, em uma rede de computadores relativamente grande.

A própria universidade desenvolve seus próprios softwares. Para isso, possui um grupo ligado diretamente a chancelaria, composta por um diretor e vários profissionais envolvidos na área de sistemas (Diretoria de Informática).

O grupo da Diretoria de Informática é composto por três subgrupos divididos por áreas de atuação. São eles: grupo de redes, de desenvolvimento e de suporte.

Os softwares que foram desenvolvidos e que já estão em uso pela universidade são:

1. O Software para Controle Acadêmico: responsável por todas as informaçōes que dizem respeito à parte acadêmica da universidade, como notas de alunos, dependências, dados pessoais dos alunos, disciplinas, professores, horários e muitos outros. Esse software é muito requisitado por professores, departamentos e secretarias, principalmente para emissão de relatórios; 
2. O Software para Controle de Vestibular: fornece todo o suporte para o vestibular que ocorre uma vez a cada ano. O software armazena e processa todas as informações relacionadas ao exame de vestibular como carreiras, candidatos, notas, e outros;

3. O Software para Controle de Finanças: realiza o controle do patrimônio da universidade.

O sistema escolhido para realizar a avaliação foi o Sistema de Controle Acadêmico. Essa escolha foi realizada por ser o sistema mais utilizado e por que novos projetos, para agregar outras funcionalidades, estavam sendo planejados.

Incluir novas funcionalidades ao sistema, foi o principal motivo da preocupação em se estabelecer um processo gerencial que garantisse que as novas inclusões ou modificações pudessem ser realizadas de maneira segura e organizada.

\subsection{A Utilização do Modelo IDEAL}

Conforme apresentado no capítulo 4, o Modelo IDEAL (inicias dos estágios propostos) é uma abordagem para melhoria de processo de software recomendada pela SEl, a qual é composta de cinco estágios: Inicialização (Initiating), Diagnóstico (Diagnosing), Ação (Acting), Estabelecimento (Establishing) e Lições (Leaming) [Dunaway, 1996]. A fase de Inicialização do processo de melhoria contém as atividades de Estabelecer Contexto e Definir Patrocinador. A partir dessa fase, o processo de melhoria entra num ciclo que permite a continuidade da melhoria, sempre buscando o aperfeiçoamento do processo de software.

O estudo de caso em particular envolveu as fases de Inicialização e Diagnóstico.

\subsubsection{Fase de Inicialização do Estudo de Caso}

Nessa fase, o estímulo para melhoria, geralmente consiste de fatores externos ao processo de software, como mudança nas estratégias de negócio, mudança na cultura da organizaçāo, necessidade de redução de custo, diminuição do tempo de desenvolvimento. No caso do projeto em questão, uma mudança cultural global dentro de toda a universidade 
alavancou a necessidade de se melhorar o processo de software para que esse pudesse ser efetivamente acompanhado e controlado.

O estabelecimento do contexto e do patrocinador foi decidido junto ao diretor de informática. O projeto escolhido foi uma instância do processo de software do sistema de controle acadêmico e o patrocinador foi definido como sendo a própria universidade, pois o objetivo era realizar melhoria de um processo interno.

\subsubsection{A Fase de Diagnóstico do Estudo de Caso}

Para o desenvolvimento dessa fase foi utilizada a estratégia proposta pelo CAF. São três as fases propostas: Planejamento e Preparação da Avaliação, Condução da Avaliação e Reporte dos Resultados.

\section{Fase 1 - Planejamento e Preparação da Avaliação}

Nessa fase foram realizadas as seguintes atividades:

Identificação do Alcance da Avaliação

O objetivo da avaliação foi identificado como sendo a verificação da situação atual do projeto em relação ao cumprimento das áreas-chave propostas pelo nível 2 do $\mathrm{CMM}$, com o intuito de realizar melhoria interna. As áreas-chave consideradas são apresentadas na Figura 6.1.

\section{Atividades Avaliadas}
1. Gerenciamento de Requisitos
2. Planejamento de Projeto de Software
3. Acompanhamento e Supervisão de Projeto de Software
4. Gerenciamento de Subcontratados de Software
5. Gerenciamento de Configuração de Software
6. Garantia de Qualidade de Software

Figura 6.1: Áreas-chave do nível 2 do CMM [Paulk, 1993] 


\section{Seleção e Preparação da Equipe de Avaliadores}

A avaliação foi realizada por uma única pessoa, visto que, o número de participantes (aqueles que fornecem os dados relacionados ao processo de software) era reduzido e não foi necessário treinamento da mesma, pois essa já possuía conhecimento necessário para conduzir a avaliação (conhecimento obtido durante a realização dos cursos de graduação e pós-graduação).

\section{Desenvolvimento do Plano de Avaliação}

Exatamente nessa fase é que se aplicou o plano elaborado neste trabalho. O plano, cuja estrutura é apresentada na Figura 6.2, foi instanciado para a situação particular com base nas informações já coletadas como objetivos, escopo e restrições. O plano se encontra completa no apêndice 3 .

\begin{tabular}{|l|}
\hline Plano de Avaliação do Processo de Software \\
\hline 1. Introdução \\
1.1. Objetivo \\
1.2. Escopo \\
1.3. Papéis e Responsabilidades \\
- Patrocinador \\
- Gerente Sênior \\
- Participantes da Avaliação \\
- Avaliadores \\
1.4. Termos-Chaves \\
1.5. Referências \\
2. Atividades de Avaliação \\
2.1. Coleta e Gravação dos Dados \\
2.2. Consolidação e Validação dos Dados \\
2.3. Realização do Julgamento das Medidas \\
3. Reporte dos Resultados \\
3.1. Reporte dos Resultados da Avaliação \\
3.2. Proteção de Informações Confidenciais \\
3.3. Preservação das Gravações \\
4. Estimativas de Cronograma e Recursos \\
4.1. Cronograma \\
4.2. Recursos
\end{tabular}

Figura 6.2: Estrutura do Plano de Avaliação 


\section{Seleção e Preparação dos Participantes}

Os participantes da avaliação foram todas as 6 pessoas envolvidas com o Sistema de Controle Acadêmico. Para preparar esses participantes foi apresentada uma palestra inicial com o objetivo de realizar o esclarecimento das atividades, dos conceitos envolvidos, dos métodos utilizados, proporcionando a cada participante a oportunidade de conhecer mais profundamente a estratégia selecionada para a avaliação e para melhoria de processo de software.

O conteúdo da apresentação seguiu uma ordem crescente de complexidade em relação aos conceitos envolvidos, colocando os conceitos iniciais básicos, até os mais específicos dentro do tema apresentado. Isso foi realizado, exatamente para que todos os participantes pudessem ser colocados no mesmo nível de domínio do assunto em questão. A apresentação durou 45 minutos com um intervalo depois da primeira meia hora e foi gravada numa fita de vídeo com o intuito de fazer parte do material para treinamento posterior da universidade.

A apresentação realizada seguiu o roteiro representado na Figura 6.3.

\begin{tabular}{|c|}
\hline Palestra Inicial \\
\hline $\begin{array}{l}\text { 1. Introdução } \\
\text { 2. Conceitos Introdutórios } \\
\text { 3. CMM (Capability Maturity Model) } \\
\text { 4. Melhoria de Processo de Software } \\
\text { 5. Avaliação do Processo de Software }\end{array}$ \\
\hline
\end{tabular}

Figura 6.3: Roteiro da Palestra Inicial

\section{Fase 2 - Condução da Avaliação}

Nessa fase foram realizadas as seguintes atividades:

\section{Coleta e Gravação dos Dados}

Os dados foram coletados através do preenchimento do questionário proposto neste trabalho (apêndice 2). O questionário foi aplicado a todos os membros da equipe de 
desenvolvimento através de entrevistas. Cada entrevista foi realizada de maneira individual, levou em média uma hora de duração e todas as questōes foram respondidas de maneira satisfatória. Durante as entrevistas foram realizadas orientaçōes explicativas sobre as questōes nele contidas. Para priorizar as açōes de melhoria, os resultados foram analisados segundo o cumprimento das áreas-chave.

\section{Consolidação e Validação dos Dados}

Algumas respostas do questionário foram consideradas como realizadas, mesmo quando na realidade o fossem informalmente. Isso se deu devido à equipe envolvida com o processo de software, que por ser pequena, não exige muita formalidade no cumprimento de algumas das atividades gerenciais. A atividade de Gerenciamento de Subcontratado de Software foi excluída do contexto de melhoria do processo de software por não fazer parte das necessidades primárias.

Os dados foram analisados e interpretados de acordo com o cumprimento ou não de cada meta das áreas-chave. Todas as atividades dentro de cada meta tiveram o mesmo peso, isso é, a verificação do cumprimento das metas foi realizada através da soma de respostas sim das suas questões.

\section{Realização do Julgamento das Medidas}

As questōes foram analisadas separadamente, por metas de cada área-chave, isso é, o julgamento de cada área-chave foi baseado no cumprimento ou não das metas. Para certificar se cada meta foi cumprida, verificou-se se as atividades nela contidas foram atendidas

Alguns resultados práticos são apresentados como produto do julgamento:

a) a atividade de Gerenciamento de Requisitos é a que apresentou melhores resultados (Figura 6.4). Isso, provavelmente, se deu devido ao controle já realizado sobre os requisitos através de uma lista de atividades e modificações gerenciadas pelo próprio grupo de maneira informal. 


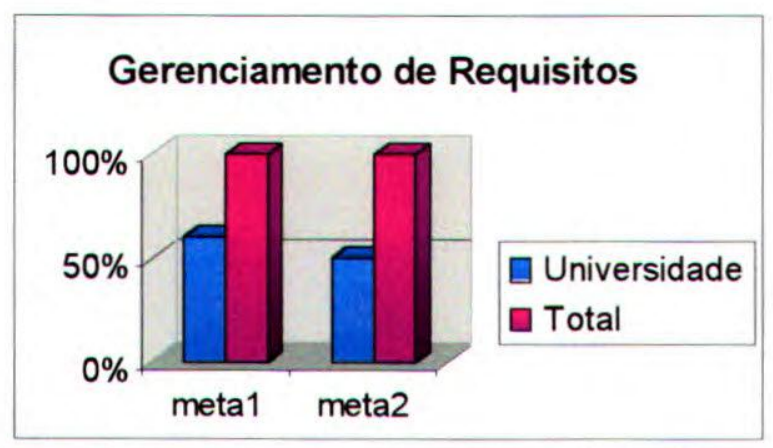

Figura 6.4: Informações sobre a área-chave Gerenciamento de Requisito

b) como pode ser visto na Figura 6.5, a atividade de Planejamento de Projeto de Software mostrou-se deficiente. A falta de documentação e de um formalismo maior para registrar as atividades, cronograma, recursos e ferramentas pode ser a causa dessa deficiência.

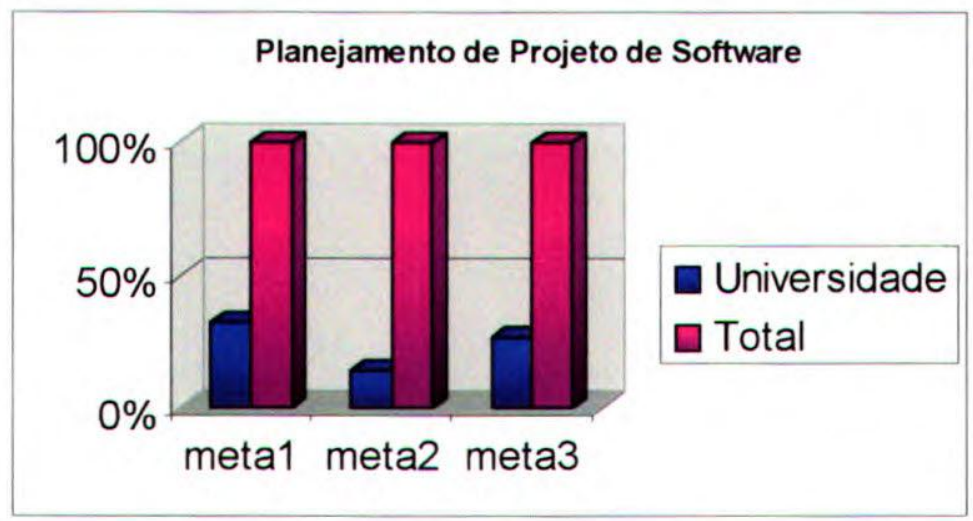

Figura 6.5: Informações sobre a área-chave Planejamento de Projeto de Software

c) quanto ao Acompanhamento e Supervisão do Projeto de Software, (Figura 6.6) podese dizer que esse também se encontra deficiente e a razão é a falta de um plano de projeto de software documentado. Existe apenas um cronograma das atividades programadas para o lançamento de cada versão, sobre o qual é realizado um controle imediato das atividades. $O$ acompanhamento e supervisão são realizados somente sobre a funcionalidade atual e a exigida futuramente do software. 


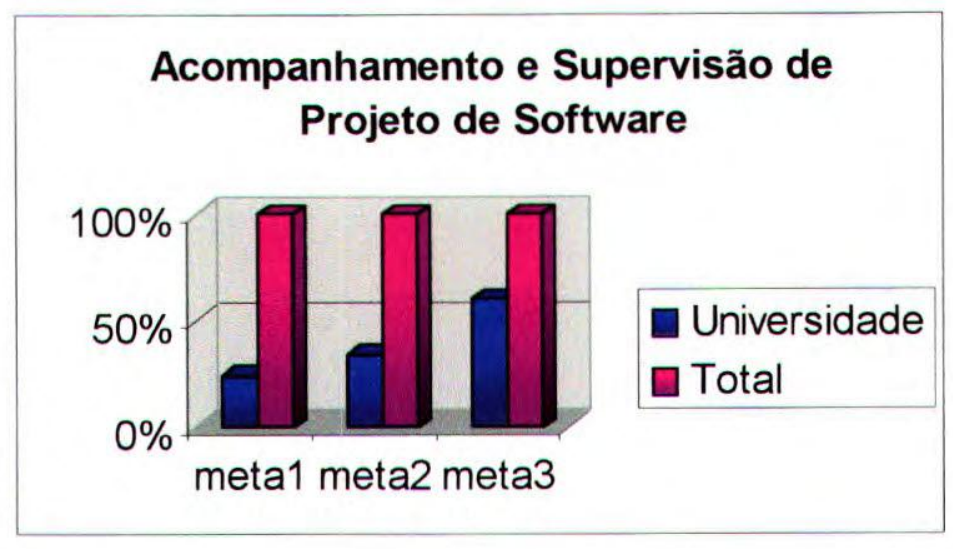

Figura 6.6: Informações sobre a área-chave Acompanhamento e Supervisão de Projeto de Software

d) a atividade de Garantia de Qualidade de Software (Figura 6.7) é a atividade que mais se apresentou deficiente no processo de software em questão, por não existir um meio de garantir um controle maior sobre todo o andamento do projeto.

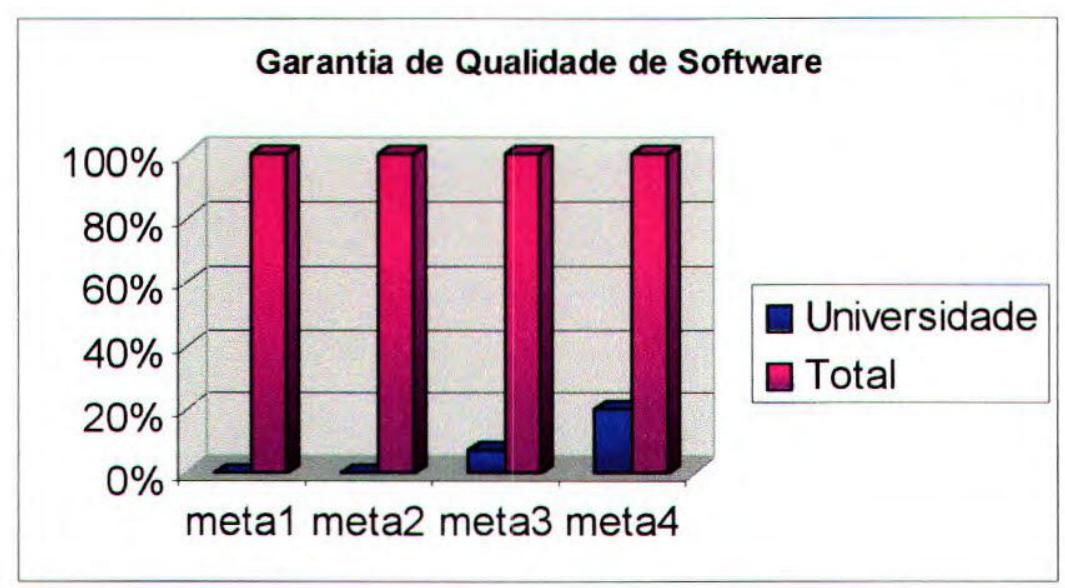

Figura 6.7: Informações sobre a área-chave Garantia de Qualidade de Software

e) a atividade de Gerenciamento de Configuração de Software (Figura 6.8) se encontrou também deficiente pois não existem planos, normas e procedimentos estabelecidos que evidenciem o cumprimento dessa atividade. 


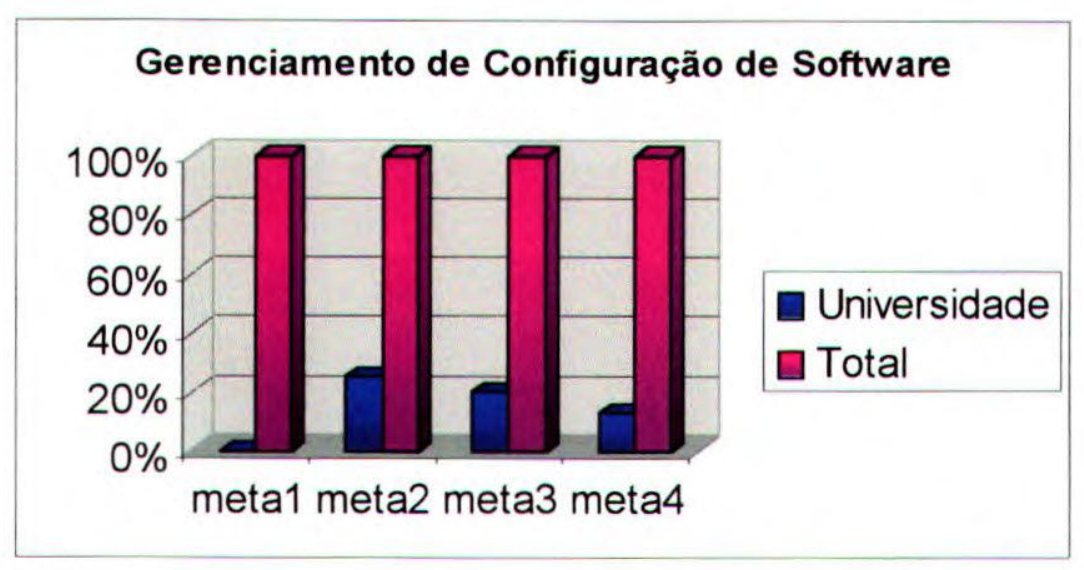

Figura 6.8: Informações sobre a área-chave Gerenciamento de Configuração de Software

\section{Fase 3 - Reporte dos Resultados}

Nessa fase foram realizadas as seguintes atividades:

Reporte dos Resultados da Avaliação

Para reportar os resultados foi elaborado um relatório parcial que descreve todas as atividades realizadas. Contém também os resultados da avaliação e os próximos passos dentro do processo de melhoria.

Nesse relatório foram re-apresentados em forma de anexos, o plano de avaliação, os slides da palestra de conscientização, o questionário e todas as informações em relação aos resultados da avaliação.

\section{Proteção de Informações Confidenciais}

A confidencialidade das respostas foi mantida, as respostas de cada participante se encontram em posse da avaliadora para posteriores estudos. As informações aqui divulgadas não comprometem, em nada, a proteção das informações. 


\section{Preservação das Gravações}

Todas as informações referentes a avaliação estão armazenadas para serem usadas, caso seja necessário. O plano, o questionário, a palestra (em forma de vídeo), o relatório apresentado. Isso foi realizado, pensando-se em ter informações armazenadas para posteriores consultas. Ou mesmo, por que é um material que já está disponível, caso se deseje fazer outra avaliação.

Ainda nessa atividade, foram realizadas algumas observações em relação à avaliação. Essas observações serão guardadas para um possível aperfeiçoamento do plano numa próxima instanciação.

- o questionário está longo e o seu preenchimento é uma tarefa cansativa;

- a palestra inicial envolveu muitos conceitos novos para a maioria dos participantes, devendo ser mais elaborada, dependendo do público alvo;

- o plano não apresentou problemas, mas não continha as informaçōes referentes aos riscos da avaliação;

- para o reporte de dados não foi realizada uma reunião, o relatório foi simplesmente entregue ao gerente sênior.

\subsection{Considerações Finais}

Neste capítulo foram apresentadas as condiçōes em que foi desenvolvido o estudo de caso, bem como todos os detalhes que foram considerados para instanciar a estratégia para uma avaliação real. A condição encontrada para realizar o estudo de caso reflete uma realidade comum em ambientes de desenvolvimento de software interno de grandes organizações brasileiras.

No capítulo seguinte, uma breve conclusāo com algumas consideraçōes sobre a realização do trabalho e trabalhos futuros são apresentados. 


\section{Capítulo 7 - Conclusões e Trabalhos Futuros}

\subsection{Conclusões}

Devido à emergente preocupaçāo que se tem sentido no mercado, em busca da qualidade, muitas empresas que desenvolvem software têm procurado melhorar seu processo de software, visto que com isso, têm-se maior probabilidade de obter um produto final mais adequado às expectativas do cliente [Gillies, 1993].

Dentro desse contexto, muitas abordagens para melhoria de processo de software desenvolvidas por órgãos como a SEI (IDEAL, CAF, CMM) e a ISO (SPICE) puderam ser estudadas e utilizadas como base, para elaborar um plano de avaliação e melhoria do processo de software de uma organização

Melhoria de processo é uma decisão de negócio que depende de toda a organização. Seus resultados geralmente, não podem ser percebidos instantaneamente, fazendo com que as pessoas acabem adiando a decisão de se fazer melhoria. Um primeiro passo que deve ser dado, é verificar a situação real em que se encontra a empresa para saber o quão perto ou longe se encontra de um objetivo traçado. Para isso, um plano de avaliação de processo de software foi proposto.

A execução desse plano faz parte de uma estratégia de avaliação disciplinada e que ajuda a priorizar, definir e controlar as açōes que devem ser tomadas no processo de avaliação. Nessa execução, faz-se necessária a utilização de um instrumento de avaliação que, também foi desenvolvido neste trabalho.

Com a realização do trabalho, é possível pensar numa avaliação rápida e segura para pequenos grupos de desenvolvedores de software que pensam em adotar um processo de software, como "a sua maneira" de desenvolver software.

Resumidamente, o trabalho apresenta os seguintes produtos:

1. Um Plano de Avaliação de Processo de Software;

2. Um questionário baseado nas áreas-chave do nível 2 do $\mathrm{CMM}$ 
A Figura 7.1 representa a utilização de cada tecnologia em cada atividade ou elemento da avaliação. As abreviações da figura representam respectivamente:

CAF: CMM Appraisal Framework

CMM-2: Capability Maturity Model, Level2

QM/SEI: Maturity Questionnaire for Software Engineering Institute

GQM: Goal-Question-Metric

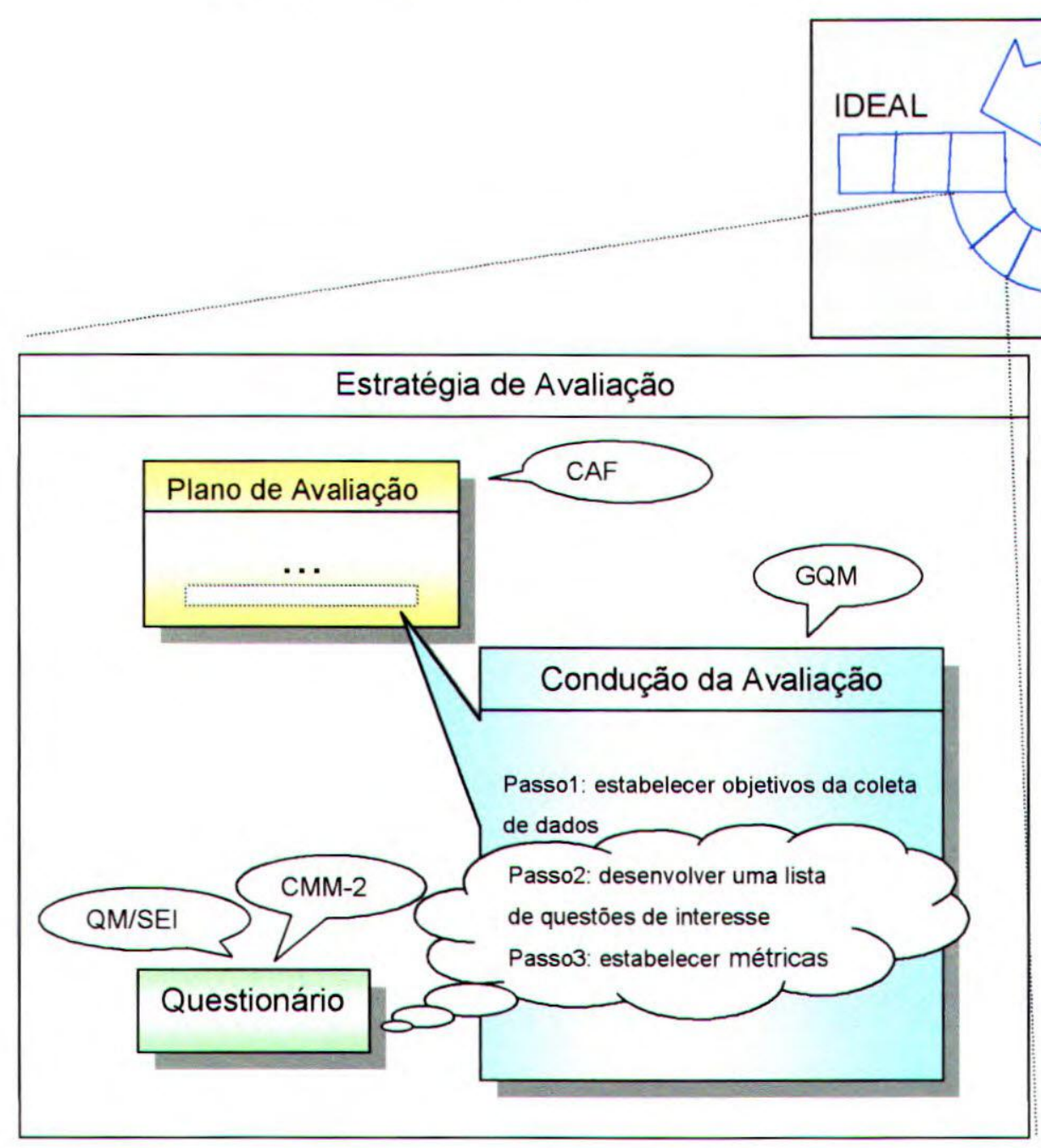

Figura 7.1: Estratégia criada para a fase de Diagnóstico do IDEAL

A estratégia elaborada neste trabalho pode ser de grande ajuda para organizações pequenas, que já sentiram a necessidade de mudar o seu próprio panorama de desenvolvimento de software, mas que ainda consideram o investimento nesse tipo de tecnologia muito além da sua disponibilidade. 
Este trabalho, 'através do estudo de várias abordagens existentes do mercado, utilizados por empresas de consultorias, pode facilitar e principalmente proporcionar um meio fácil e eficiente de realizar um diagnóstico da sua própria empresa.

\subsection{Trabalhos Futuros}

Atualmente, o processo técnico de desenvolvimento de software possui grande ajuda de métodos, técnicas e ferramentas que facilitam muito a vida dos desenvolvedores, mas 0 processo gerencial ainda precisa ser muito melhorado.

Espera-se que num futuro, não muito distante, o software possa ser desenvolvido com mais segurança nas previsões e estimativas realizadas no momento do contrato. Para isso, é necessário que se consolide um processo de gerenciamento de software que tenha qualidade e que seja capaz de garantir que o produto seja produzido com as características desejadas, no prazo e custo estipulado.

Nesse contexto é que se insere a melhoria de processo de software. Ela é uma atividade que envolve muita dedicação e investimento, e o diagnóstico do processo real compreende, somente, o primeiro passo do árduo trabalho. Esse pequeno passo, no entanto, é imprescindível, visto que um processo de melhoria é elaborado a partir dos pontos fortes e fracos identificados na organização.

Para consolidar um processo desse tipo, é necessário definir os pontos fracos e fortes de uma organização com o próximo passo em mente. Esse próximo passo é definir um plano de ação que implante, de fato, a melhoria desejada, dentro do ciclo de melhoria de processo.

Algumas técnicas que auxiliam a desenvolver esse plano de ação, baseado nas prioridades definidas pelo diagnóstico e também nos objetivos de negócio da organização, podem ajudar muito a seqüência de atividades rumo à melhøria de processo de software. 


\section{Referência Bibliográfica}

[Abbot, 1955]

[Andrade, 1996]

[Arruda, 1998]

[Basili, 1995]

[Buckley, 1993]

[Cavano, 1978]

[Coallier, 1994]

[Crosby, 1979]
ABBOT, L., Quality and Competion, Nova York, Columbia University Press, 1955.

ANDRADE, A. L.; e outros, Aplicação da norma ISO 12119 na Avaliação da Qualidade de Produtos de Software, VII CITS, Curitiba, 1996.

ARRUDA, M. N. P., Avaliação CMM - A Experiência do CPqD TELEBRÄS, WQS'98, Maringá, 1998.

BASILI, V.R.; CALDIERA,G. e ROMBACH, H.D., Goal-QuestionMetric Paradigm, Encyclopedia of Software Engineering, John Wiley \& Sons, Nova York, v.1, p.527-532, 1995.

BUCKLEY, F. J., Implementing a Software Configuration Management Enviroment, IEEE Computer, v. 27, n. 2 , p. 56-61, 1994.

CAVANO, J. P.; e J. A. MCCALL, A Framework for the Measurement of Software Quality, Proceeding ACM Software Quality Assurence Workshop, novembro, 1978.

COALLIER, F.; e outros, Trillium - Model for Telecom Product Development \& Support Process Capability, Internet Edition, release 3.0, Bell Canada, 1994.

CROSBY, P. B., Quality Is Free, The Art of Making Quality Certain, McGraw-Hill, Nova York, 1979. 
[Curtis, 1992]

[Deming, 1990]

[DoD-Std 2168]

[Dunaway, 1996]

[Feigenbaun, 1961]

[Garmus, 1996]

[Gillies, 1993]

[Grady, 1997]

[Gremba, 1998]

[Humphrey, 1989]
CURTIS, M. I.; KELLNER, J., Process Modelling, Communications of $A C M$, v. 35, n. 9, setembro, 1992.

DEMING, W. E., Qualidade - a Revolução da Administração, Marques Saraiva, Rio de Janeiro, 1990.

Dod-Std-2168, Department of Defense Standard of Software Quality Evaluation.

DUNAWAY, D. K.; MASTERS, S., CMM Based Appraisal for Internal Process Improvement: Method Description, Relatório Técnico TR-96-007,Software Engineering Institute, 1996.

FEIGENBAUN, A. V., Total Quality Control, McGrall-Hill, Nova York,1961.

GARMUS, D., Measuring the Sofware Process: a practical guide to functional measurements, Prentice-Hall, Nova Jersey, 1996.

GILLIES, A., Software Quality: Theory and Management, Chapman\&Hall, Longman, 1993.

GRADY, R. B., Successful software process improvement, Prentice-Hall, Nova Jersey, 1997.

GREMBA, J.; MYERS, C., The IDEAL Process Model: A Practical Guide for /mprovement, http://www.sei.cmu.edu/activities/ideal/ ideal.bridge.html, [acessado em 25/08/98].

Humphrey, W. S., Managing the Software Process, AddisonWesley Publs, 1989. 
[IEEE Std 729 - 1983] IEEE Standard Glossary of Software Engineering Terminology, Software Engineering Technical Commitee of the IEEE Computer Society, 1983.

[ISO/IEC 9126, 1994] ISO/IEC 9126, Tecnologia de Informação-Avaliação do Produto de Software - Caracteristica de Qualidade de Diretrizes para o seu Uso - Versão brasileira em processo de votação pela ABNT com numeração: NBR-ISO/IEC 9126, junho, 1994.

[Juran, 1970]

Juran, J. M.; Gryna, Jr., Quality Planning an Analysis From Product Development to Use, McGrall-Hill, Nova York, 1990.

[Kan, 1995]

KAN, S.H., Metrics and Models in Software Quality Engineering, Addison-Wesley, EUA, 1995.

[Kirner, 1997]

KIRNER, T. G.; ABIB, J. C., Uso da Abordagem GQM na Avaliação da Qualidade de Software, WQS'97, Fortaleza, 1997.

[Lemes, 1997]

TAURION, C., A busca da Qualidade para Alavancar os Negócios, Developers Magazine, 1997.

[Madhavji, 1991]

MADHAVJI, N. H., The Process Cycle, Software Engineering Journal, v. 6, n. 5, setembro, 1991.

[Marciniat, 1994]

MARCINIAT, J. J., Encyclopedia of Software Engineering, Wiley Intersciense Publications, v.ll, p. 851-869, 1994.

[Masters, 1995]

MASTERS S.; BOTHWELL C., CMM Appraisal Framework version 1.0, Relatório Técnico TR-95-001, Software Engineering Institute, 1995.

[McCall, 1977]

MCCALL, J.; RICHARDS, P.;WALTERS, G., Factors in Software Quality, NTIS AD-A049-014,015,055, novembro, 1977. 
[MCT, 1997]

[Oliveira, 1995]

[Pacheco, 1997]

[Paladini, 1990]

[Paulk, 1993]

[Paulk, 1995]

[Pressman, 1994]

[Rombach, 1987]

[Sanders, 1994]
MINISTÉRIO DA CIÊNCIA E TECNOLOGIA, Qualidade no setor de software brasileiro,1997.

OLIVEIRA, A. L. M., Processo de Software - Visão Global, Relatório Técnico - Fundação CTI - Brasil , Campinas, 1995.

PACHECO, R. F.; SANCHES R., Gerenciamento de Configuração de Software, Relatório Técnico - ICMSC, n. 57, junho, 1997.

PALADINI, E. P., Controle de Qualidade - Uma Abordagem Abrangente, Editora Atlas AS - 1990.

PAULK, M. C.;CURTIS, B.;CHRISSIS, M. B.; WEBER, C. V., Capability Maturity Model for Software, version 1.1, CMU/SEI-93TR-24, fevereiro, 1993.

PAULK, M. C.; KONRAD, M. D.; GARCIA, S. M., CMM and SPICE Architectures, Software Process Newsletters, IEEE Computer Society Technical Council on Software Engineering, $n$. 3, p. 7-11, primavera, 1995.

PRESSMAN, R. S., Software Engineering - A Practitioner's Approach, Edição Européia, McGraw-Hill, 1994.

ROMBACH, H. D., A Controled Experiment on the Impact of Software Structure on Maintainability, IEEE Transaction on Software Engineering, v.SE-13, 1987.

SANDERS, J.; CURRAN, E., Software Quality - "A framework for success in software development and suport", Addison-Wesley, 1994. 
[SEl, 1997]

[Smith, 1989]

[SPICE1, 1997]

[SPICE2, 1997]

[SPICE4, 1997]

[SPICE7, 1997]

[Taurion, 1998]

[Tsukumoto, 1995]

[Werkema, 1995]
SOFTWARE ENGINEERING INSTITUTE, The Capability Maturity Model: Guidelines for Improving the Software Process, AddisonWesley, Longman, 1997.

SILVA, L. A., Qualidade de Software: Manifestações aos Clientes, Developers Magazine, 1998.

SMITH, D. J.; WOOD, K. B., Englneering Quality Software - "A review of current practices standards and guidelines including new methods and development tool", Elsevier Science Publishers Ltd., 1989.

ISO/IEC Software Process Assessment - Part 1: Concepts and Introdutory Guide, Working Draft, versão 1.00, 1997.

ISO/IEC Software Process Assessment - Part 2: A Model for Process Management, Guide, Working Draft, versão 1.00, 1997.

ISO/IEC Software Process Assessment - Part 4: Guide to Conducting Assessment, Working Draft, versão 1.00, 1997.

ISO/IEC Software Process Assessment - Part 7: Guide for Use in Process Improvement, Working Draft vesion 1.00, 1997.

TAURION, C., A busca da qualidade para alavancar os negócios, Developers Magazine, 1997.

TSUKUMOTO, N. A.; e outros, Modelos de Processo de Software: Visão Global e Análise Comparativa, Fundação CTI Brasil, Campinas, 1995.

WERKEMA, M. C. C., Ferramentas industriais básicas para o 
gerenciamento de processos, Fundação Christiano Ottoni, 1995.

[Zubrow, 1994]

ZUBROW, D.; e outros, Maturity Questionnaire, Relatório Técnico, SR-94-7, Software Engineering Institute, 1994. 


\section{Apêndice 1}

(As Práticas-Chave do Nível 2 do CMM) 
Este anexo apresenta o nível 2 do CMM de maneira completa.

Apresentam-se as metas e as práticas-chave de cada área-chave do nível 2.

As práticas-chave utilizadas na elaboração do questionário proposto pelo trabalho são as Tarefas. A elaboração detalhada desse questionário está descrita no capítulo 5.

\section{Gerenciamento de Requisitos}

A finalidade dessa área-chave é estabelecer um entendimento comum entre cliente e a equipe do projeto sobre os requisitos do software que serão abordados. Isso envolve documentar e controlar os requisitos do cliente e manter os planos, produtos e atividades consistentes com esses requisitos.

As práticas-chave dessa área-chave são apresentadas a seguir divididas em metas e cinco características comuns: compromisso para realizar, condições para desempenhar, tarefas, medição e análise $\theta$ verificação.

\section{Metas}

1: os requisitos do sistema alocados para o software são controlados para estabelecer uma linha de referência (baseline) para a engenharia de software e para o uso no gerenciamento; 2: planos de software, produtos e atividades são mantidos consistentes com os requisitos do sistema alocados para o software;

\section{Compromisso para Realizar}

1: o projeto segue uma política organizacional estabelecida para gerenciar os requisitos do sistema alocados para o software;

\section{Condiçōes para Desempenhar}

1: estabelece-se responsabilidades para cada projeto para analisar os requisitos do sistema e para alocá-los ao hardware, ao software e a outros componentes do sistema;

2: os requisitos alocados são documentados;

3: os recursos adequados e os fundos são fornecidos para gerenciar os requisitos alocados.

4: os membros do grupo de engenharia de software e outros grupos relacionados são treinados para desempenhar suas atividades gerenciais requeridas.

\section{Tarefas}

1: o grupo de engenharia de software revisa os requisitos alocados antes de eles serem incorporados ao projeto de software. 
2: o grupo de engenharia de software usa os requisitos alocados como base para os planos do software, produtos de trabalhos e atividades.

3: as mudanças nos requisitos alocados são revistas e incorporadas no projeto de software.

\section{Medição e Análise}

1: as medidas são feitas e usadas para determinar a situação das atividades para gerenciar os requisitos alocados.

\section{Verificação}

1: as atividades para gerenciar os requisitos alocados são revistas com o gerente sênior com uma certa periodicidade.

2: as atividades para gerenciar os requisitos alocados são revistas com o gerente de projeto periodicamente e baseado em eventos ocorridos.

3: o grupo de garantia de qualidade revisa e/ou acessora as atividades e o produto de trabalho para gerenciar os requisitos alocados e reporta os resultados.

\section{Planejamento de Projeto de Software}

A finalidade dessa área-chave é estabelecer planos razoáveis para desenvolver e gerenciar o processo de software. Isso envolve desenvolver estimativas, determinar os compromissos e definir um plano para realizar o trabalho. Esse plano deve conter o ciclo de vida do projeto de software, uma lista de produtos a serem entregues ao cliente, prazos, estimativas para o nível de esforço, recursos, ferramentas de suporte e riscos do projeto.

As práticas-chave dessa área-chave são apresentadas a seguir divididas em metas e cinco características comuns: compromisso para realizar, condições para desempenhar, tarefas, medição e análise e verificação.

\section{Metas}

1: as estimativas de software são documentadas para serem utilizadas no planejamento e acompanhamento do projeto de software

2: as atividades de projeto de software e compromissos são planejadas e documentadas.

3: os grupos e os indivíduos afetados obedecem aos seus compromissos relacionados ao projeto de software. 


\section{Compromisso para Realizar}

1: um gerente de projeto de software é designado para ser responsável pela negociação dos compromissos e para desenvolver o plano de desenvolvimento do projeto de software.

2: o projeto segue a polftica organizacional estabelecida para o planejamento de um projeto de software.

\section{Condiçōes para Desempenhar}

1: existe uma estrutura documentada e aprovada de trabalho para o projeto de software 2: são associadas às responsabilidades para desenvolver o plano de desenvolvimento de software.

3: os recursos e os fundos adequados são fornecidos para planejar o projeto de software.

4: os gerentes de software, os engenheiros de software e outros individuos envolvidos no planejamento do projeto de software são treinados para realizar estimativas e planejar os procedimentos aplicáveis a suas áreas de responsabilidade no planejamento.

\section{Tarefas}

1: o grupo de engenharia de software participa da equipe que propõe o projeto.

2: planejamento do projeto de software é inicializado por estágios primitivos e em paralelo com o planejamento geral do projeto.

3: o grupo de engenharia de software participa com outros grupos afetados no planejamento geral do projeto durante toda a vigência do projeto.

4: os compromissos do projeto de software atribuídos a grupos ou indivíduos externos á organização são revistos pelo gerente sênior de acordo com o procedimento documentado.

5: um ciclo de vida com estágios pré-definidos e de tamanho gerenciável săo identificados ou definidos.

6: o plano de desenvolvimento do projeto de software é desenvolvido de acordo com os procedimentos documentados.

7: o plano para o projeto de software é documentado.

8: identifica-se os produtos de trabalhos de software que são necessários estabelecer e manter controle no projeto de software.

9: estimativas do tamanho do produto de trabalho são derivadas de acordo com os procedimentos documentados.

10: as estimativas de esforço e custos de projeto de software sāo derivadas de acordo com os procedimentos documentados.

11: as estimativas para o projeto de recursos computacionais críticos são derivadas de acordo com os procedimentos documentados. 
12: o cronograma do projeto de software é derivado de acordo com os procedimentos documentados.

13: os riscos de software associados aos custos, recursos, cronograma e aspectos técnicos do projeto são identificados, avaliados e documentados.

14: planos para as facilidades de engenharia de software e ferramentas de suportes são preparados.

15: dados do planejamento de software são guardados.

\section{Medição e Análise}

1: as medidas são realizadas e usadas para determinar a situação das atividades de planejamento do software.

\section{Verificação}

1: as atividades do planejamento do projeto de software são revistas com o gerente sênior periodicamente.

2: as atividades do planejamento do projeto de software são revistas com o gerente de projeto periodicamente e baseado em ocorrência de eventos.

3: o grupo de garantia de qualidade revisa e/ou acessora as atividades e os produtos de trabalhos do planejamento do projeto de software e reporta os resultados.

\section{Acompanhamento e Supervisão do Projeto de Software}

A finalidade dessa área-chave é oferecer visibilidade adequada do progresso real do projeto, de modo que o gerenciamento possa tomar medidas efetivas quando o desempenho se desvia significativamente do plano. Isso envolve acompanhar e revisar os resultados e as realizações do software confrontando com as estimativas documentadas, compromissos e planos. Envolve, também, ajustar os planos com base nos resultados e realizações efetivamente alcançados. Os mecanismos utilizados para isso podem ser revisōes internas e revisões formais com clientes. Quando ocorre um desvio entre os planos e os resultados efetivos, deve-se alterar a forma como o trabalho está sendo feita e/ou ajustar os planos.

As práticas-chave dessa área-chave são apresentadas a seguir divididas em metas e cinco características comuns: compromisso para realizar, condições para desempenhar, tarefas, medição e análise $\Theta$ verificaçăo.

\section{Metas}

1: os resultados reais e desempenhos são acompanhados em relação ao plano de software; 
2: as açōes corretivas sāo tomadas e gerenciadas quando os resultados reais e o desempenho desviam significativamente do plano de software;

3: as mudanças nos compromissos de software são obedecidas pelos indivíduos e grupos afetados;

\section{Compromisso para Realizar}

1: um gerente de projeto de software é designado para ser responsável pelas atividades do projeto de software, bem como os seus resultados;

2: o projeto segue uma política organizacional estabelecida para o gerenciamento do projeto de software;

\section{Condições para Desempenhar}

1: um plano de desenvolvimento de software para o projeto de software é documentado e aprovado;

2: o gerente de projeto de software atribui explicitamente as responsabilidades para o produto de trabalho de software e atividades;

3: os recursos adequados e os fundos são fomecidos para acompanhar o projeto de software;

4: os gerentes de software são treinados para gerenciar os aspectos técnicos e humanos do projeto de software;

5: os gerentes de software de primeira linha recebem orientação nos e custos aspectos técnicos do projeto de software;

\section{Tarefas}

1: um plano de desenvolvimento de software documentado é usado para acompanhar as atividades de software e para comunicar a situação atual;

2: o plano de desenvolvimento de software é revisado de acordo com os procedimentos documentados;

3: os compromissos do projeto de software e mudanças nesses compromissos associados a indivíduos ou grupos externos a organização são revisados com o gerente sênior de acordo com os procedimentos documentados;

4: as mudanças de compromissos aprovados que afetam o projeto de software são comunicadas aos membros do grupo de engenharia de software e outros grupos relacionados; 5: o tamanho do produto de trabalho de software (ou o tamanho da mudança no produtos e trabalho de software) são acompanhados e ações corretivas são tomadas se necessário; 6: o esforço e o custo do projeto de software são acompanhados e ações corretivas são tomadas se necessário; 
7: os recursos críticos do projeto são acompanhados e açōes corretivas são tomadas se necessário;

8: o cronograma do projeto de software é acompanhado e ações corretivas são tomadas se necessário;

9: as atividades técnicas de engenharia de software são acompanhadas e ações corretivas são tomadas se necessário;

10: os riscos de software associados ao custo, recursos, cronogramas e aspectos técnicos do projeto são acompanhados;

11: dados de medidas reais e dados para o replanejamento do projeto de software são gravados;

12: o grupo de engenharia de software conduz periodicamente uma revisão interna para acompanhar o progresso técnico, planos, desempenho e questões em relação ao plano de desenvolvimento de software;

13: as revisōes formais para verificar o cumprimento e resultado do projeto de software sāo conduzidos nos marcos estabelecidos de acordo com o procedimento documentado;

\section{Medição e Análise}

1: as medidas são realizadas e usadas para determinar a situação do acompanhamento do software e das atividades de supervisão;

\section{Verificação}

1: as atividades para o acompanhamento do projeto de software e supervisão são revistas com o gerente sênior periodicamente;

2: as atividades para o acompanhamento do projeto de software e supervisão são revistas com o gerente de projeto periodicamente e baseado na ocorrência de alguns eventos;

3: o grupo de garantia de qualidade revisa e/ou acessora as atividades e o produto de trabalho para o acompanhamento e supervisão do projeto de software e reporta os resultados;

\section{Gerenciamento de Subcontrato de Software}

A finalidade dessa área-chave é selecionar fornecedores (que se responsabilizam por parte do trabalho) qualificados e gerenciá-los eficazmente. Isso envolve selecionar o fornecedor, estabelecer compromissos, acompanhar e revisar o desempenho e os resultados obtidos. $\mathrm{Na}$ seleção e gerenciamento do fornecedor são necessários documentos como: cláusula de contrato, requisitos do projeto, produtos a serem entregues, padrões e procedimentos a serem seguidos. 
As práticas-chave dessa área-chave são apresentadas a seguir divididas em metas e cinco características comuns: compromisso para realizar, condições para desempenhar, tarefas, medição e análise e verificação.

\section{Metas}

1: o contratante seleciona os subcontratado de software qualificado;

2: o contratante e o subcontratado de software concordam com os compromissos de cada lado;

3: o contratante e o subcontratado de software mantêm comunicação;

4: o contratante acompanha o resultado real e desempenho do subcontratado de software em relação aos seus compromissos;

\section{Compromisso para Realizar}

1: o projeto segue uma política organizacional estabelecida para gerenciar o subcontratado de software;

2: um gerente de subcontratado de software é designado para ser responsável para estabelecer e gerenciar o subcontrato de software;

\section{Condições para Desempenhar}

1: os recursos adequados e os fundos são fornecidos para selecionar o subcontratado de software e gerenciar o subcontratado;

2: os gerentes de software e outros indivíduos que estão envolvidos em estabelecer e gerenciar o subcontrato de software são treinados para desempenhar essas atividades;

3: os gerentes de software e outros indivíduos que estão envolvidos em estabelecer e gerenciar o subcontrato de software recebem orientação nos aspectos técnicos do subcontrato;

\section{Tarefas}

1: o trabalho a ser realizado pelo subcontratado é definido e planejado de acordo com os procedimentos documentados;

2: o subcontratado de sof tware é selecionado baseado numa avaliaçăo da habilidade de desempenhar o trabalho proposto pelo subcontratado de acordo com os procedimentos documentados;

3: a concordância contratual entre o contratante e o subcontratado de software é usada como uma base para gerenciamento do subcontrato;

4: um plano de desenvolvimento do subcontratado de software documentado é revisto e aprovado pelo contratante;

5: um plano de desenvolvimento do subcontratado de software documentado e aprovado é usado para acompanhar as atividades de software e comunicar a situação; 
6: mudanças na estrutura de trabalho do subcontratado de software, termos do subcontrato, condições e outros compromissos são resolvidos de acordo com os procedimentos documentados;

7: o gerente do contratante conduz periodicamente uma revisão da situação e da coordenação com os gerentes do subcontratados;

8: as revisões técnicas periódicas e intercâmbio são realizados com o subcontratado de software;

9: as revisões formais para verificar o cumprimento da engenharia de software por parte do subcontratado de software são conduzidos e marcas são selecionadas de acordo com os procedimentos documentados;

10: o grupo de garantia de qualidade do contratante monitora as atividades de garantia de qualidade do subcontratado de acordo com os procedimentos documentados;

11: o grupo de gerenciamento de configuração de software monitora as atividades de gerenciamento de configuração de software do subcontratado de acordo com os procedimentos documentados;

12: o contratante conduz o teste de aceitação como parte do produto de liberação de software do subcontratado de acordo com os procedimentos documentados;

13: o desempenho do subcontratado de software é avaliado periodicamente e revisado com o subcontratado;

\section{Medição e Análise}

1: as medidas são feitas e usadas para determinar a situação da atividades para o gerenciamento do subcontratado de software;

\section{Verificação}

1: as atividades para o gerenciar o subcontratado de software são revistas com o gerente sênior periodicamente;

2: as atividades para o gerenciar o subcontratado de software são revistas com o gerente de projeto periodicamente e baseado na ocorrência de alguns eventos;

3: o grupo de garantia de qualidade revisa e/ou acessora as atividades e o produto de trabalho para gerenciar o subcontratado de software e reporta os resuitados;

\section{Garantia de Qualidade de Software}

A finalidade dessa área-chave é oferecer gerenciamento, com visibilidade apropriada, do processo que está sendo utilizado e dos produtos que estão sendo construídos. Isso envolve revisōes e auditorias nos produtos de software e nas atividades para assegurar que estão em 
conformidade com os padrões e procedimentos aplicados. Envolve também fornecer esses resultados para os gerentes envolvidos.

As práticas-chave dessa área-chave são apresentadas a seguir divididas em metas e cinco características comuns: compromisso para realizar, condições para desempenhar, tarefas, medição e análise e verificação.

\section{Metas}

1: as atividades de garantia de qualidade de software são planejadas

2: a conformidade dos produtos de software e atividades ao padrão aplicado, aos procedimentos e aos requisitos é verificada objetivamente;

3: os grupos e indivíduos envolvidos são informados sobre as atividades de garantia de qualidade e de seus resultados;

4: os problemas de questões que não podem ser resolvidos no projeto de software são encaminhados ao gerente sênior;

\section{Compromisso para Realizar}

1: o projeto segue uma política organizacional para implementar a garantia de qualidade de software (GQS);

\section{Condições para desempenhar}

1: existe um grupo responsável pela coordenação e implementação do GQS: grupo de GQS;

2: recursos adequados e fundos são fornecidos para desempenhar as atividades de GQS;

3: os membros do grupo de GQS sāo treinados para desempenhar as atividades de GQS;

4: os membros do projeto de software recebem orientação dos papéis, responsabilidades, autoridade e valores do grupo de GQS;

\section{Tarefas}

1: um plano de GQS é preparado para o projeto de software de acordo com os procedimentos documentados;

2: as atividades do grupo de GQS são desempenhadas de acordo com o plano de GQS;

3: o grupo de GQS participa da preparação e revisão do: plano de desenvolvimento de software, padrões e procedimentos;

4: o grupo de GQS revisa as atividades de engenharia de software para verificar seu cumprimento;

5: O grupo de GQS dá auditoria a produtos de trabalhos de softwares para verificar seu cumprimento; 
6: o grupo de GQS reporta periodicamente os resultados das atividades ao grupo de engenharia de software;

7: os desvios identificados nas atividades de software e nos produtos de trabalhos de software são documentados e manipulados de acordo com os procedimentos documentados;

8: o grupo de GQS conduz revisões periódicas das atividades $\theta$ das despesas com o pessoal de GQS do cliente, apropriadamente;

\section{Medição e Anáilise}

1: as medições são feitas e usadas para determinar a situação dos custos e cronogramas das atividades de GQS;

\section{Verificação}

1: as atividades de GQS são revisadas com o gerente sênior periodicamente;

2: as atividades de GQS são revistas com o gerente de projeto periodicamente e baseado na ocorrência de alguns eventos;

3: especialistas independentes ao grupo GQS revisam periodicamente as atividades $\theta 0$ produto de trabalho do projeto do grupo de GQS;

\section{Gerenciamento de Configuracão do Software}

A finalidade dessa área-chave é estabelecer $\theta$ manter a integridade dos produtos do projeto de software ao longo do ciclo de vida do software. Isso envolve identificar os itens de configuração, controlar sistematicamente as alterações e manter a integridade da configuração ao longo do ciclo de vida do software. O gerenciamento da configuração utiliza linhas de referência (baselines) que servem como um marco no ciclo de vida do software. Os itens que passam por uma linha de referência podem ser alterados somente através de procedimentos formais de controle de mudanças.

As práticas-chave dessa área-chave são apresentadas a seguir divididas em metas e cinco características comuns: compromisso para realizar, condiçōes para desempenhar, tarefas, medição e análise e verificação.

\section{Metas}

1: as atividades de gerenciamento de configuração de software são planejadas;

2: produtos de trabalhos de software selecionados são identificados, controlados e disponibilizados;

3: mudanças em produtos de trabalhos de software identificados são controlados; 
4: os grupos e indivíduos envolvidos são informados sobre a situação e conteúdos das linhas de referências (baseline);

\section{Compromisso para Realizar}

1: o projeto segue uma política organizacional escrita para implementar o gerenciamento de configuraçāo de software (GCS);

\section{Condiçōes para Desempenhar}

1: existe uma unidade com autoridade para gerenciar as linhas de referência

2: existe um grupo que é responsável pela coordenação e implementação do gerenciamento de configuração de software : grupo de GCS;

3: os recursos e fundos adequados são fornecidos para desempenhar as atividades de GCS;

4: os membros do grupo de GCS são treinados para os objetivos, os procedimentos e os métodos para desempenhar as atividades de GCS;

5: os membros do grupo de engenharia de software e outros grupos relacionados ao software sāo treinados para desempenhar suas atividades de GCS;

\section{Tarefas}

1: um plano de GCS é preparado para cada projeto de software de acordo com os procedimentos documentados;

2: um plano de GCS documentado e aprovado é usado como base par desempenhar as atividades de GCS;

3: uma biblioteca de gerenciamento de configuração é estabelecida como um repositório para as linhas de referência do software;

4: os produtos de trabalho de software colocados sobre gerenciamento de configuração são identificados;

5: os pedidos de mudanças e relatório de problemas são inicializados, revistos, aprovados e acompanhados para todos os itens/unidades de configuração, de acordo com os procedimentos documentados;

6: as mudanças nas linhas de referências são controladas de acordo com os procedimentos documentados;

7: os produtos da biblioteca da linha de referência de software são criados e suas versōes são controladas de acordo com os procedimentos documentados;

8: a situaçăo dos itens/unidades de configuraçāo é registrada de acordo com os procedimentos documentados;

9: os relatórios padrões documentando as atividades de GCS e o conteúdo das linhas de referência de software é desenvolvido e disponibilizado aos grupos e indivíduos envolvidos; 
10: as auditorias para linhas de referências de software são conduzidos de acordo com os procedimentos documentados;

\section{Medição e Análise}

1: as medidas são realizadas e usadas para determinar a situação das atividades de GCS;

\section{Verificação}

1: as atividades de GCS são revisadas com o gerente sênior periodicamente;

2: as atividades de GCS são revistas com o gerente de projeto periodicamente e baseado na ocorrência de alguns eventos;

3: o grupo de GCS audita periodicamente as linhas de referências do software para verificar se elas estão conforme a documentação que as define;

4: o grupo de garantia de qualidade revisa e/ou audita as atividades e produtos de trabalhos de software do GCS para reportar os resultados. 
Apêndice 2

(O Questionário de Avaliação) 


\section{Questionário}

(Avaliação de Aspectos Gerenciais do Processo de Software Tomando como Base o CMM) 


\section{Î́ndice}

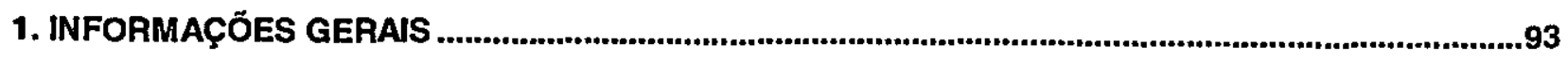

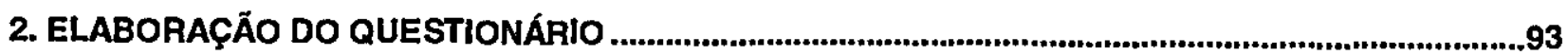

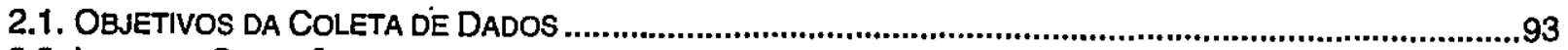

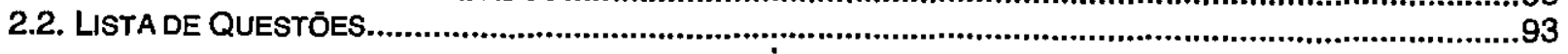

3. INSTRUÇŌES PARA PREENCHIMENTO DO QUESTIONÁRIO ........................................................94

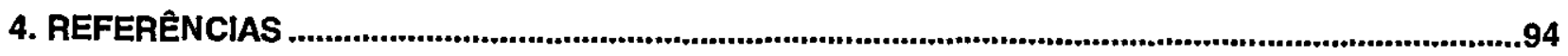

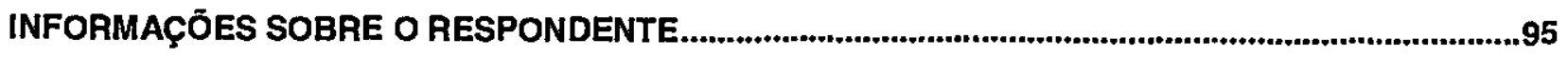

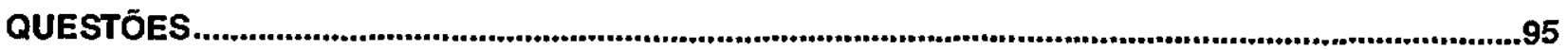

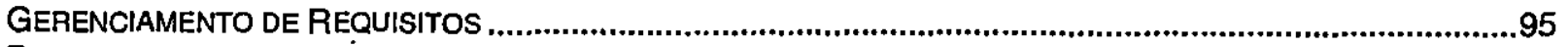

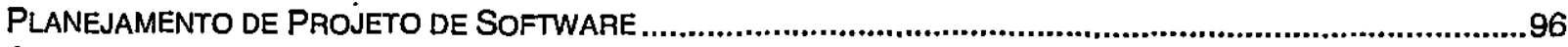

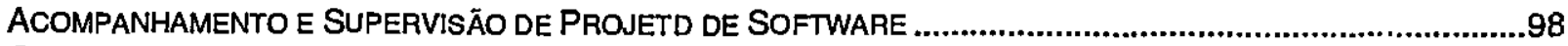

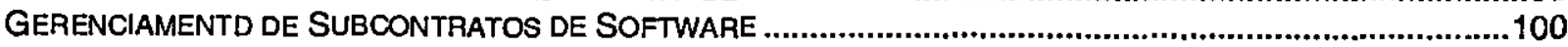

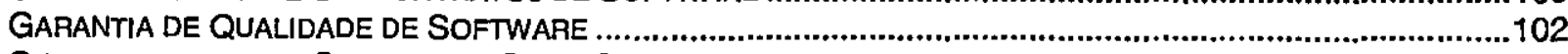

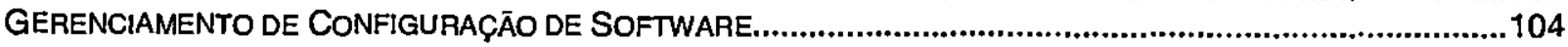




\section{Informações Gerais}

Este documento apresenta um questionário para avaliar aspectos gerenciais do processo de software tomando como base o nível 2 do Modelo CMM (Capability Matury Model).

O questionário deve ser preenchido durante entrevistas, quando também serão realizadas orientações explicativas sobre as questões nele contidas.

Esse questionário faz parte de um processo de avaliação baseado num plano de avaliação para processo de software e pretende caracterizar o processo de software segundo as 6 áreas-chaves propostas pelo nível 2 do CMM.

\section{Elaboração do Questionário}

Para a elaboração do questionário utilizou-se um método denominado GoalQuestion-Metric (GQM) [Basili], o qual já foi empregado em muitos projetos de pesquisas em Engenharia de Software [Rombach]

Esse método fomece um mecanismo que orienta a determinação dos objetivos de interesse da análise e o refinamento de cada objetivo em um conjunto de questões como propósito para quantificar os mesmos. Tais questões definem um conjunto específico dos dados a serem coletados.

\subsection{Objetivos da Coleta de Dados}

\begin{tabular}{|l|l|}
\hline Objeto & Processo de Software \\
\hline Propósito & Verificar a qualidade do Processo \\
\hline Foco de Qualidade & Áreas-chave do nível 2 do CMM \\
\hline Ponto de Vista & Administrativo \\
\hline Ambiente & Grupo de Desenvolvimento de Software \\
\hline
\end{tabular}

\subsection{Lista de Questões}

O questionário contém questões que dizem respeito a implementação e institucionalização das áreas-chave propostas pelo nível 2 do CMM. Essas questões estão organizadas, em grupos, segundo as metas de cada uma das 6 (seis) áreaschave desse nível. As perguntas são baseadas nas tarefas que devem ser realizadas para atingir cada meta proposta.

As respostas serão consideradas informações confidenciais. 


\section{Instruções para Preenchimento do Questionário}

1. As quatro possíveis respostas para cada questão são: Sim, Não, Não se Aplica $\Theta$ Não Sei

A reposta Sim deve ser assinalada quando:

A prática é bem estabelecida e desempenhada consistentemente.

( $A$ prática pode ser desempenhada quase sempre e permite considerar bemestabelecida e consistentemente desempenhada como um procedimento padrāo)

A resposta Não deve ser assinalada quando:

A prática não é bem estabelecida ou é realizada inconsistentemente. dificuldade)

( $A$ prática pode até ser desempenhada mas é omitida diante de alguma

A resposta Não se Aplica deve ser assinalada quando:

A prática em questão não se aplica ao contexto avaliado.

(Por exemplo, todas as questões em relação ao Gerenciamento de Subcontratados de Software, quando não existe parte do projeto sob responsabilidade de um subcontratado)

A resposta Não Sei deve ser assinalada quando:

Não está seguro da resposta

2. Qualquer tipo de anotação em relação às questões pode ser acrescentada nos espaços assinalados reservados no fim de cada meta .

3. Todas as questöes devem ser respondidas assinalando apenas uma opção.

\section{Referências}

1. Capability Maturity Model Pratices, CMU/SEl-93-TR-25, Web-site da SEl em http://www.sei.cmu.edu/

2. Capability Maturity Model Appraisal Framework Version 1.0, CMU/SEI-95-TR001, Web-site da SEl em http://www.sei.cmu.edu/

3. Capability Maturity Model - Based Appraisal for Internal Process Improvement (CBA IPI): Method Description, CMU-96-TR-007, Web-site da SEI http://www.sei.cmu.edu

4. BASILI, V.R.; CALDEIRA,G. e ROMBACH, H.D.Goal-Question-Metric Paradigm, Encyclopedia os Software Engineering, John Wiley \& Sons, Nova York, v.1, p.527-532, 1995

5. ROMBACH, H. D., A Controled Experiment on the Impact of Software Structure on Maintainability, IEEE Transaction on Software Engineering, v.SE-13, 1987 


\section{Questionário}

\section{Informações sobre o Respondente}

Identificação do Respondente:

Data: 1

Nome do Projeto:

Telefone:

\section{Questões}

\section{Gerenciamento de Requisitos}

A finalidade dessa área-chave é estabelecer um entendimento comum entre o cliente e a equipe do projeto sobre os requisitos alocados ao software. Isso envolve documentar e controlar os requisitos do cliente e manter os planos, produtos e atividades consistentes com esses requisitos.

\section{Meta1}

Os requisitos do software serem controlados por uma linha de referência (baseline) para o uso da engenharia de software e no gerenciamento.

1: O grupo de engenharia de software revisa os requisitos alocados antes deles serem incorporados ao projeto de software?

Sim Não Não se Aplica Năo Sei

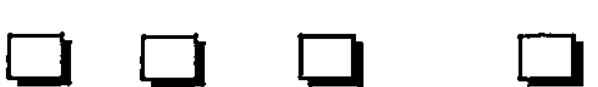

Anotações:

Meta2

Os planos de software, produtos e atividades serem mantidos consistentes com os requisitos do software. 
2: 0 grupo de engenharia de software usa os requisitos como base para os planos do software, produtos de trabalhos e atividades?

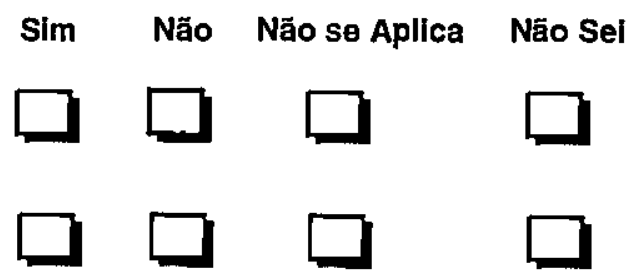

3: As mudanças nos requisitos alocados são revistas $e$ incorporadas ao projeto de software?.....

Anotações:

\section{Planejamento de Projeto de Software}

A finalidade dessa área-chave é estabelecer planos razoáveis para desenvolver e gerenciar o processo de software. Isso envolve desenvolver estimativas, determinar os compromissos e definir um plano para realizar o trabalho. Esse plano deve conter o ciclo de vida do projeto de software, uma lista de produtos a serem entregues ao cliente, prazos, estimativas para o nível de esforço, recursos, ferramentas de suporte e riscos do projeto.

\section{Meta1}

As estimativas de software serem documentadas para serem utilizadas no planejamento e acompanhamento do projeto de software.

9: As estimativas de tamanho de produto de trabalho são realizadas?.

10: As estimativas de esforço e custos de projeto de software são realizadas ?.

11: As estimativas para o projeto de recursos computacionais críticos são realizadas?.

12: O cronograma do projeto de software é estabelecido?

15: Todas as informaçóes obtidas durante 0 planejamento de software são registradas ?...

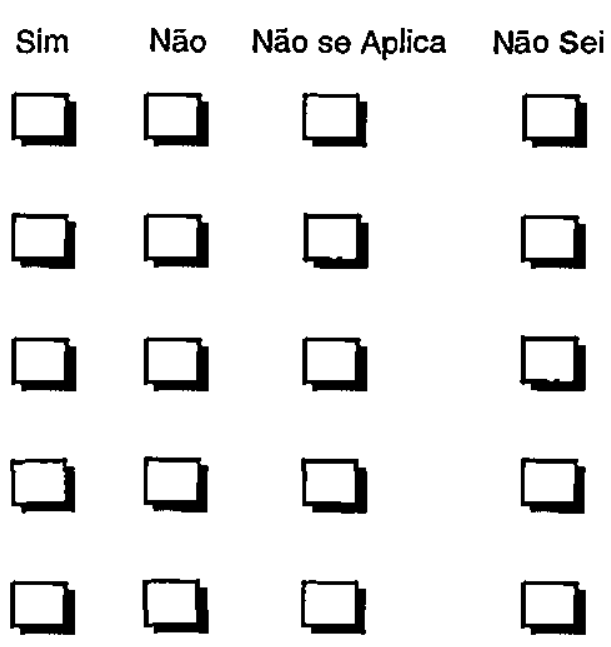

Anotações: 


\section{Meta2}

As atividades de projeto de software e compromissos serem planejados $\theta$ documentados.

2: O planejamento do projeto de software é iniciado antes e em paralelo com o planejamento geral do projeto?.

Sim Não Não se Aplica Não Sei

5: Um ciclo de vida com estágios pré-definidos de tamanho $\theta$ de gerenciável são identificados ou definidos?

6: O plano de desenvolvimento do projeto de software é desenvolvido?

7: Esse plano de desenvolvimento para o projeto de software é documentado?.

8: Identificam-se os produtos de trabalhos de software que são necessários estabelecer e manter controle no projeto de software?.
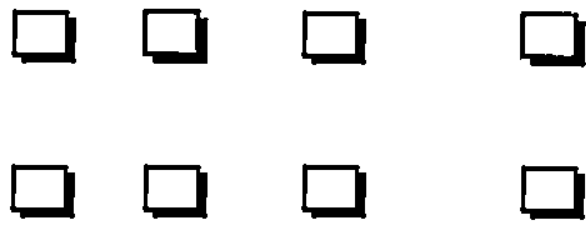

13: Os riscos de sottware associados aos custos, recursos, cronograma e aspectos técnicos do

projeto sāo identificados, avaliados e documentados?

14: Os planos para as atividades de engenharia de software $\Theta$ ferramentas de suportes são preparados?

\section{。}

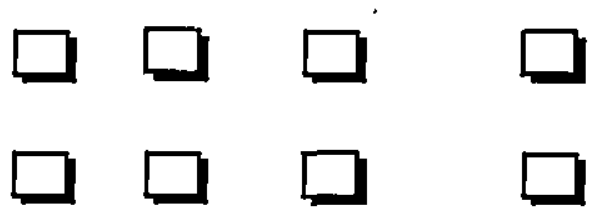

$\square \square \square$

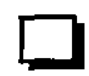

$\square \quad \square \quad \square$

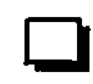

Anotaçōes:

\section{Meta3}

Os grupos e os indivíduos envolvidos obedecerem aos seus compromissos relacionados ao projeto de software.

1: O grupo de engenharia de software participa da equipe que propōe o projeto?

3: 0 grupo de engenharia de software participa com outros grupos envolvidos no planejamento geral do projeto durante toda a vigência do projeto?.

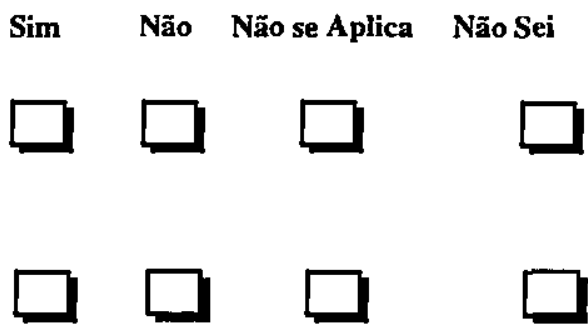


Sim Näo Não se Aplica Năo Sel

4: Os compromissos do projeto de software atribuídos a grupos ou indivíduos externos à organização são revistos pelo gerente sênior ?........

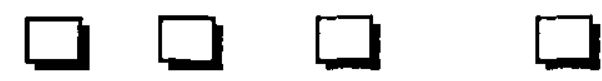

Anotações:

\section{Acompanhamento e Supervisão de Projeto de Software}

A finalidade dessa área-chave é oferecer visibilidade adequada do progresso real do projeto, de modo que o gerenciamento possa tomar medidas efetivas quando o desempenho se desvia significativamente do plano. Isso envolve acompanhar e revisar os resultados e as realizações do software confrontando com as estimativas documentadas, compromissos $\theta$ planos. Envolve, também, ajustar os planos com base nos resultados e realizações efetivamente alcançados. Os mecanismos utilizados para isso podem ser revisões internas e revisőes formais com clientes. Quando ocorre um desvio entre os planos e os resultados efetivos, deve-se alterar a forma como 0 trabalho está sendo feita e/ou ajustar os planos.

\section{Meta1}

Os resultados reais e desempenho do projeto serem acompanhados em relação ao plano de software.

1: Um plano de desenvolvimento de software documentado $\dot{\theta}$ usado para acompanhar as atividades de software e para comunicar a situação atual?

5: O tamanho do produto de trabalho de software (ou o tamanho da mudança no produto e trabalho de software) sāo acompanhados $\theta$ açōes corretivas são realizadas se necessário?

6: O esforço e o custo do projeto de software são acompanhados e ações corretivas são tomadas se necessário?

7: Os recursos críticos do projeto sāo acompanhados e ações corretivas são tomadas se

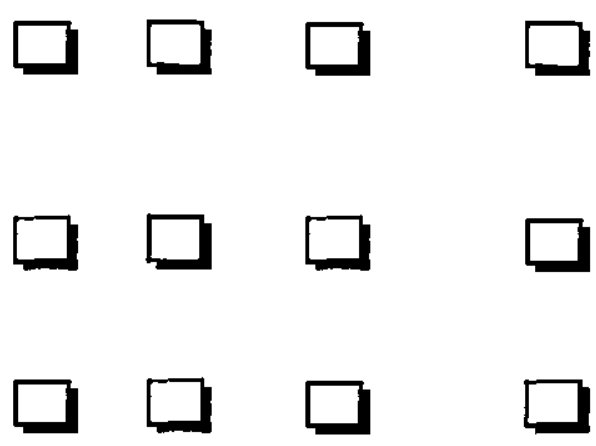


necessário?

Sim

Não Não se Aplica

Năo Sei

8: O cronograma do projeto de software é acompanhado $\theta$ açōes corretivas são tomadas se necessário?.

9: As atividades técnicas de engenharia de software são acompanhadas e açöes corretivas são tomadas se necessário?

10: Os riscos de software associados ao custo, recursos, cronogramas e aspectos técnicos do projeto são acompanhados?.

11: Os dados de medidas reais e dados para o replanejamerito do projeto de software são gravados?

12: O grupo de engenharia de software conduz periodicamente uma revisão interna para acompanhar o progresso técnico, planos, desempenho e questões em relação ao plano de desenvolvimento de software?.

13: As revisões formais para verificar o cumprimento e resultado do projeto de software são conduzidos nos marcos estabelecidos?
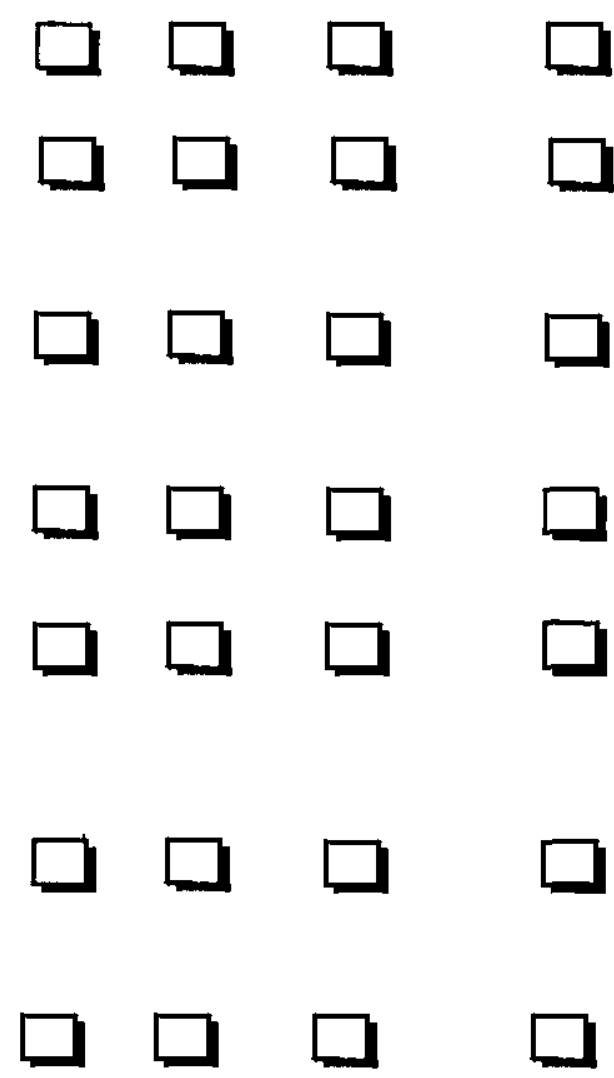

Anotações:

\section{Meta2}

As ações corretivas serem realizadas e gerenciadas quando os resultados reais e o desempenho desviarem significativamente do plano de software.

2: O plano de desenvolvimento de software é revisado?

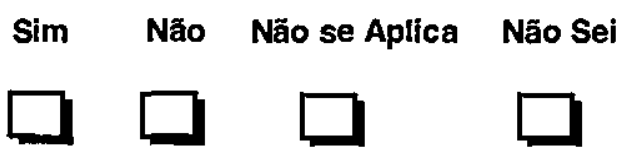

Anotações:

\section{Meta3}


As mudanças nos compromissos de software serem obedecidas pelos indivíduos e grupos envolvidos.

3: Os compromissos do projeto de software $\theta$ mudanças nesses compromissos associados a indivíduos ou grupos externos a organização são revisados com o gerente sénior?

Sim Não Năo se Aplica Năo Sei

4: As mudanças de compromissos aprovados que afetam o projeto de software säo comunicadas aos membros do grupo de engenharia de software e outros grupos relacionados?

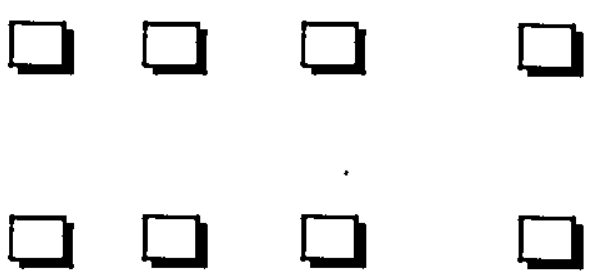

Anotações:

\section{Gerenciamento de Subcontratos de Software}

A finalidade dessa área-chave é selecionar fornecedores (que se responsabilizarn por parte do trabalho) qualificados e gerenciá-los eficazmente. Isso envolve selecionar o fornecedor, estabelecer compromissos, acompanhar e revisar o desempenho e os resultados obtidos. Na seleção e gerenciarnento do fornecedor são necessários docurnentos corno: cláusula de contrato, requisitos do projeto, produtos a serem entregues, padröes e procedimentos a serem seguidos.

\section{Meta1}

O contratante selecionar os subcontratado de software qualificado.

1: O trabalho a ser realizado pelo subcontratado é definido e planejado?

Sim Não Năo se Aplica Não Sei

2: O subcontratado de software é selecionado baseando-se numa avaliação da habilidade de desempenhar 0 trabalho proposto pelo subcontratado?.
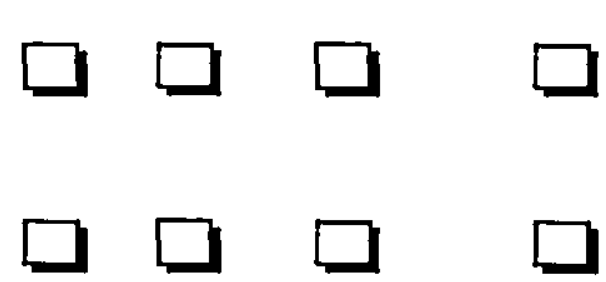

Anotações: 


\section{Meta2}

O contratante e o subcontratado de software concordarem com os compromissos de ambas as partes.

3: A concordância contratual entre o contratante e o subcontratado de software é usada como uma base para gerenciamento do subcontrato?

Sim Năo Năo se Aplica Năo Sei
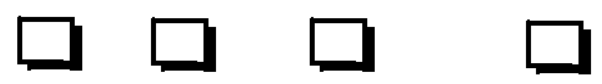

4: Um plano de desenvolvimento de software do subcontratado é documentado revisto e aprovado pelo contratante?

6: As mudanças na estrutura de trabalho do subcontratado de software, termos do subcontrato, condições e outros compromissos são resolvidos em comum acordo com ambas as partes envolvidas: contratante e subcontratado?

Anotaçōes:

\section{Meta3}

O contratante e o subcontratado de software manterem comunicação.

SIm Não Não se Aplica Não Sei

7: O gerente do contratante conduz periodicamente uma revisão da situação e da coordenação com os gerentes do subcontratados?

8: As revisões técnicas periódicas e troca das informaçōes são realizadas com o subcontratado de software?

9: As revisões formais para verificar o cumprimento das atividades de engenharia de software por parte do subcontratado de software são conduzidos e os marcos selecionados?

são

13: O desempenho do subcontratado de software é avaliado periodicamente e revisado com 0 subcontratado?

Anotações: 


\section{Meta4}

O contratante acompanhe o resultado real e desempenho do subcontratado de software em relação aos seus compromissos.

5: Um plano de desenvolvimento de software do subcontratado documentado e aprovado é usado para acompanhar as atividades de software $e$ comunicar a situação?.

10: O grupo de garantia de qualidade do contratante monitora as atividades de garantia de qualidade do subcontratado para verificar se os planos, padrōes e procedimentos estäo sendo seguidos?

11: O grupo de gerenciamento de configuração de software monitora as atividades de gerenciamento de configuração de software do subcontratado para verificar se os planos, padrões $\theta$ procedimentos estão sendo seguidos?

12: O contratante conduz o teste de aceitação da parte do produto de liberação de software do subcontratado?..
Sim Não Não se Aplica Não Sei
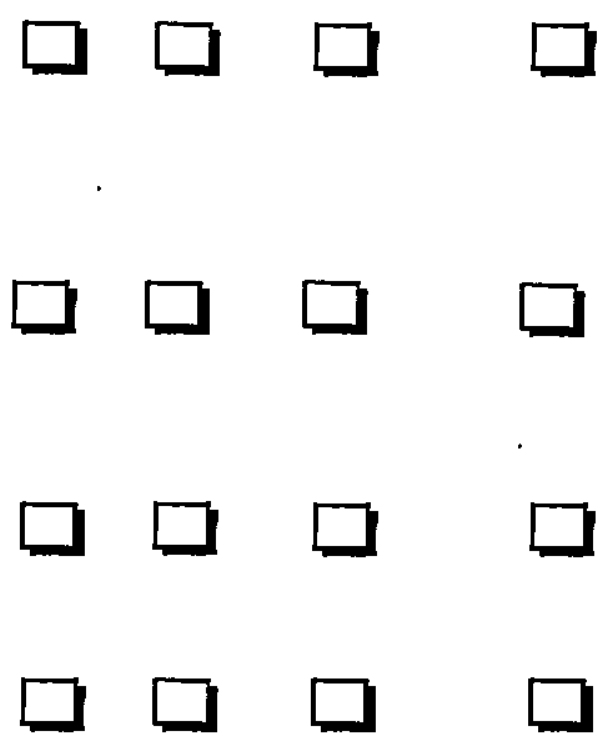

Anotaçőes:

\section{Garantia de Qualidade de Software}

A finalidade dessa área-chave é oferecer gerenciamento, com visibilidade apropriada, do processo que está sendo utilizado e dos produtos que estão sendo construídos. Isso envolve revisöes e auditorias nos produtos de software e nas atividades para assegurar que estão em conformidade com os padrōes e procedimentos aplicados. Envolve também fomecer esses resultados para os gerentes envolvidos. 


\section{Meta1}

As atividades de garantia de qualidade de software serem planejadas.

1: Um plano para Garantia de Qualidade de Software é preparado para o projeto de software?

Sim Não Não se Aplica Năo Sei

2: As atividades do grupo de Garantia de Qualidade de Software são desempenhadas de acordo com o plano?

Anotações:

\section{Meta2}

A conformidade dos produtos de software e atividades ao padrão aplicado, aos procedimentos e aos requisitos ser verificada objetivamente.

3: O grupo de Garantia de Qualidade de Software participa da preparação e revisão do: plano de desenvolvimento de software, padrōes e procedimentos?

Sim Nāo Não se Aplica Não Sei

4: O grupo de Garantia de Qualidade de Software revisa as atividades de engenharia de software para verificar seu cumprimento?.
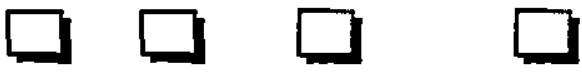

5: O grupo de Garantia de Qualidade de Software dá auditoria a produtos de trabalhos de softwares para verificar seu cumprimento?..
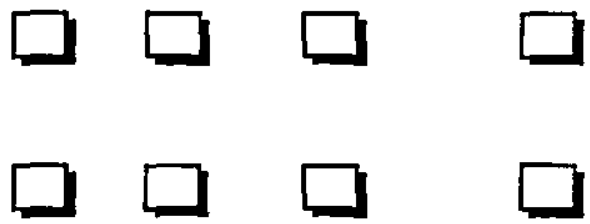

Anotações:

\section{Meta3}

Os grupos e individuos envolvidos serem informados sobre as atividades de garantia de qualidade e de seus resultados.

Sim Não Não se Aplica Não Sei

6: O grupo de Garantia de Qualidade de Software reporta periodicamente os resultados das 
atividades ao grupo de engenharia de software?

7: Os desvios identificados nas atividades de software e nos produtos de trabalhos de software são documentados e manipulados ?

8: O grupo de Garantia de Qualidade de Software conduz revisões periódicas das atividades e das descobertas com 0 pessoal de Garantia de Qualidade de Software do cliente, apropriadamente?.

Anotaçōes:

\section{Meta4}

Os problemas de questōes que não podem ser resolvidos no projeto de software serem encaminhados ao gerente sênior.

7: Os desvios identificados nas atividades de software e nos produtos de trabalhos de software são documentados e manipulados ?

Sim Năo Não se Aplica Não Sei

Anotações:

\section{Gerenciamento de Configuração de Software}

A finalidade dessa área-chave é estabelecer e manter a integridade dos produtos do projeto de software ao longo do ciclo de vida do software. Isso envolve identificar os itens de configuração, controlar sistematicamente as alterações e manter a integridade da configuração ao longo do ciclo de vida do software. O gerenciamento da configuração utiliza linhas de referência (baselines) que servem como um marco no ciclo de vida do software. Os itens que passam por uma linha de referência podem ser alterados somente através de procedimentos formais de controle de mudanças.

\section{Meta1}

As atividades de gerenciamento de configuração de software serem planejadas. 
1: Um plano de Gerenciamento de Configuração de Software é preparado para cada projeto de software?

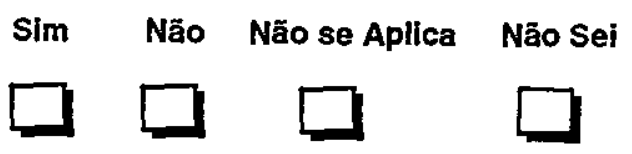

Anotações:

\section{Meta2}

Os produtos de trabalhos de software selecionados serem identificados, controlados e disponibilizados.

3: Uma biblioteca de gerenciamento de configuração é estabelecida como um repositório para as linhas de referência do software?

Sim Não Não se Apiica Năo Sel

4: Os produtos de trabaiho de software colocados sobre gerenciamento de configuraçāo são identificados?

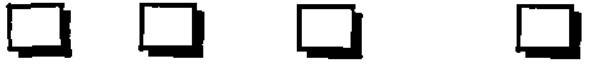

7: Os produtos da biblioteca da linha de referência de software são criados e suas versões são controladas?.

Anotações:

\section{Meta3}

As mudanças em produtos de trabalhos de software identificados serem controladas.

5: Os pedidos de mudanças e relatório de problemas são inicializados, revistos, aprovados e acompanhados para todos os itens/unidades de configuração?

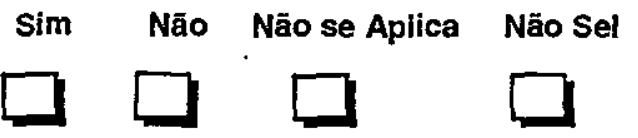

6: As mudanças nas linhas de referências são controladas?.

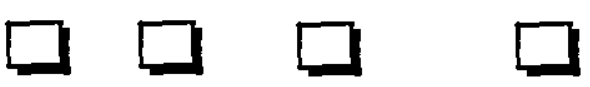


Anotaçōes:

\section{Meta4}

Os grupos e indivíduos envolvidos serem informados sobre a situação $\theta$ conteúdos das linhas de referências (baseline).

8: A situação dos itens/unidades de configuração é registrada?.

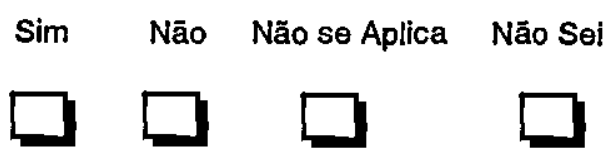

9: Os relatórios padrões documentando as atividades de Gerenciamento de Configuração de Software e o conteúdo das linhas de referência de software é desenvolvido e disponibilizado aos grupos e indivíduos envolvidos?.

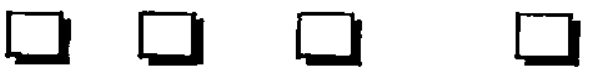

10: As auditorias para linhas de referências de software são conduzidas?

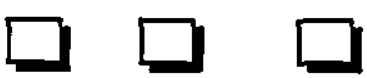

Anotações: 


\section{Apêndice 3 (O Plano de Avaliação)}




\title{
Plano de Avaliação de Processo de Software
}

\author{
para
}

Equipe de Desenvolvimento do SCA

\author{
a ser apresentada para a
}

Diretoria de Informática da

Universidade

Preparado por:

Cristina Endo

Baseado em:

CAF (CMM Appraisal Framework) 


\section{Sumário}

1. Introdução

1.1. Objetivo

1.2. Escopo

1.3. Papéis e Responsabilidades

- Patrocinador

- Gerente Sênior

- Participanites

- Avaliadores

1.4. Termos-Chaves

1.5. Referências

2. Atividades de Avaliação

2.1. Coleta e Gravação dos Dados

2.2. Consolidação e Validação dos Dados

2.3. Realização do Julgamento das Medidas

3. Reporte dos Resultados

3.1. Reporte dos Resultados da Avaliação

3.2. Proteção de Informações Confidenciais

3.3. Preservação das Gravações

4. Estimativas de Cronograma e Recursos

4.1. Cronograma

4.2. Recursos

\section{Plano de Avaliação de Processo de Software}

\section{Introduçẫo}

\subsection{Objetivo}

O objetivo da avaliação consiste em identificar os pontos fracos e fortes do processo de software do sistema SCA (Sistema de Controle Acadêmico) considerando as áreas-chave propostas no nível 2 do modelo CMM. Essas áreas-chave sāo:

- Processo de Gerenciamento de Configuração;

- Processo de Gerenciamento de Requisitos;

- Processo de Garantia de Qualidade;

- Processo de Planejamento de Projeto de Software;

- Processo de Acompanhamento e Supervisão do Projeto de Software;

- Processo de Gerenciamento de Subcontratados de Software. 
As informaçöes serão usadas para priorizar as atividades do plano de melhoria de processo de software.

\subsection{Escopo}

Este plano tem como finalidade organizar o processo de avaliação do ambiente de desenvolvimento do SCA ( Sistema de Controle Acadêmico) da universidade. O sistema é responsável por todas as informaçōes que dizem respeito à parte acadêmica da universidade, como notas de alunos, dependências, dados pessoais dos alunos, disciplinas, professores, horários e muitos outros. Esse software é muito requisitado por professores, departamentos e secretarias, principalmente para emissão de relatórios.

\subsection{Papéis e Responsabilidades}

Nesta subseção são identificados os responsáveis e as autoridades que devem acompanhar as atividades de avaliação.

- Patrocinador: A própria universidade;

- Gerente Sênior: O diretor de Informática tem a responsabilidade de um gerente sênior;

- Participantes: Todos os membros da equipe de desenvolvimento são participantes da avaliação respondendo o questionário;

- Availadora: Aluna de mestrado em Computação do ICMC-USP.

O responsável pela avaliação realizará um encontro inicial para apresentar os objetivos da avaliação $\theta$ esciarecer as dúvidas sobre as técnicas e os procedimentos que serão utilizados na avaliação (Palestra Inicial).

\subsection{Termos-Chaves}

áreas-chaves: práticas do modelo $\mathrm{CMM}$ que evidenciam cumprimento de atividades de engenharia de software

CMM: Capability Maturity Model, modelo de maturidade de processo de software

garantia de qualidade: atividade de engenharia de software que oferece gerenciamento do processo que está sendo usado e do produto que está sendo construído

gerenciamento de configuração: atividade de engenharia de software que tem como função manter a integridade dos produtos de software

GQM: Goal-Question-Metric abordagem que auxilia a condução de uma pesquisa

IDEAL: Initiating, Diagnosing, Acting, Establishing, Learning, abordagem de melhoria de processo de software proposta pela SEI

nível de maturidade: cada uma das categorias que o $\mathrm{CM}$ classifica as organizações 
metas: os objetivos que devem ser cumpridos para implementação de cada áreachave

práticas-chaves: tarefas que devem ser cumpridas em cada área-chave. Elas podem ser classificadas como: compromisso para realizar, condiçōes para desempenhar, tarefas, medições e análise verificação

processo de software: envolve políticas, responsabilidades, custos, cronogramas, enfim todas as variáveis que influenciam o desenvolvimento de um software

SEl: Software Engineering Institute, órgão governamental dos EUA com a sede na Universidade de Carnegie-Mellon

\subsection{Referências}

Engenharia de Software

- PRESSMAN, R. S., Engenharia de Software, 3ed, Rio de Janeiro, Makron Books, 1995;

\section{Qualidade de Software}

- KAN, S. H., Metrics and Models in Software Quality Engineering, Addison-Wesley, EUA, 1995;

- PAULK, M. C.; CURTIS, B.; CHRISSIS, M. B., Capability Maturity Model for Software, versão 1.1, CMU/SEI-93-TR-24, fevereiro, 1993;

- PAULK, M.C.; KONRAD, M.D.; GARCIA, S.M., CMM and SPICE Architectures, Software Process Newsletters, IEEE Computer Society Technical Council on Software Engineering, n. 3, p. 7-11, primavera, 1995;

- MASTERS, S.; BOTHWELL, C.,CMM Appraisal Framework,versão 1.1, Relatório

Técnico, TR-(\%-001, Software Engenineering Institute, 1995;

- GREMBA J.; MYERS, C., The IDEAL Modelo: A practical guide for improvement, http://www.sei.cmu.ed/activities/ideal/ideal.bridge.html.

Elaboração de Planos

- ANSI/IEEE Standard for Software Project Management Plans, IEEE Software Engineering Standards Collection, primavera, 1991;

- PACHECO, R. F.; SANCHES R., Gerenciamento de Configuração de Software, Relatório Técnico - ICMSC, n. 57, junho, 1997.

\section{Atividades de Avaliaçãò}

\subsection{Coleta e Gravação dos Dados}

Como instrumento de avaliação será utilizado o questionário elaborado para capturar os pontos fracos e fortes do processo em relação às áreas-chave do nível 2 do CMM.

O questionário será respondido durante entrevistas individuais com pessoas identificadas no item 1.3 deste plano. A equipe de avaliaçāo deve ter acesso a qualquer informação de suporte e registro do processo de software. 


\subsection{Consolidação e Validação dos Dados}

Primeiro os dados serão validados, isso é, será verificado se as repostas dos questionários não apresentam dados inconsistentes, se não existem questōes que não foram respondidas, ou que tenham mais de uma resposta e verificar possíveis ocorrências de erros.

Os dados coletados serão agrupados por área-chave. Cada conjunto de respostas será analisado para verificar o cumprimento ou não de cada área-chave do nível 2.

\subsection{Realização do Julgamento das Medidas}

A partir das informaçōes da atividade anterior será possível julgar cada área-chave segundo os valores: satisfeito, não satisfeito, não aplicável e não medido. No questionário proposto, todas as perguntas de cada área-chave devem ser respondidas sim para que a área-chave seja considerada satisfeita.

\section{Reporte dos Resultados}

\subsection{Reporte dos Resultados da Avaliação}

O resultado final será apresentado para a equipe e o responsável pelo projeto tem a liberdade de escolher usá-lo ou não. Durante essa apresentação é importante que a

organização, como um todo, compreenda os resultados que estão sendo apresentados e que fique explicitado os pontos fracos $\Theta$ fortes do projeto detectado pela avaliação.

Será elaborado, também um relatório que contém todas as informaçōes referentes aos resultados da avaliação.

\subsection{Proteção de Informações Confidenciais}

As respostas individuais de cada participante não serão divulgadas.

\subsection{Preservação das Gravaçōes}

Qualquer comentário sobre o processo de avaliação será guardado para aperfeiçoar a estratégia de avaliação. Os questionários respondidos, os resultados, as análises serão registrados para manter um histórico de avaliaçōes já realizadas.

\section{Estimativas de Cronograma e Recursos}

Define-se um cronograma $\theta$ estimativas de recursos iniciais. 


\subsection{Cronograma}

- contatos iniciais (3 dias)

- palestras de conscientização (1 dia)

- instanciação e apresentação do plano (1 dia)

- aplicação do questionário (6 dias)

- análise das informações (3 dias)

- divulgação dos resultados (1 dia)

\subsection{Recursos}

Os recursos que devem estar disponiveis

- sala para palestra que contenha algum meio audiovisual para exposição (lousa, retroprojetor, datashow, etc)

- ambiente para se realizar as entrevistas individuaimente

- computador com editores de texto 